\title{
SURFICIAL GEOLOGY OF THE TYONEK AREA, SOUTH-CENTRAL TYONEK QUADRANGLE, ALASKA
}

Richard D. Reger, De Anne S.P. Stevens, and Rich D. Koehler

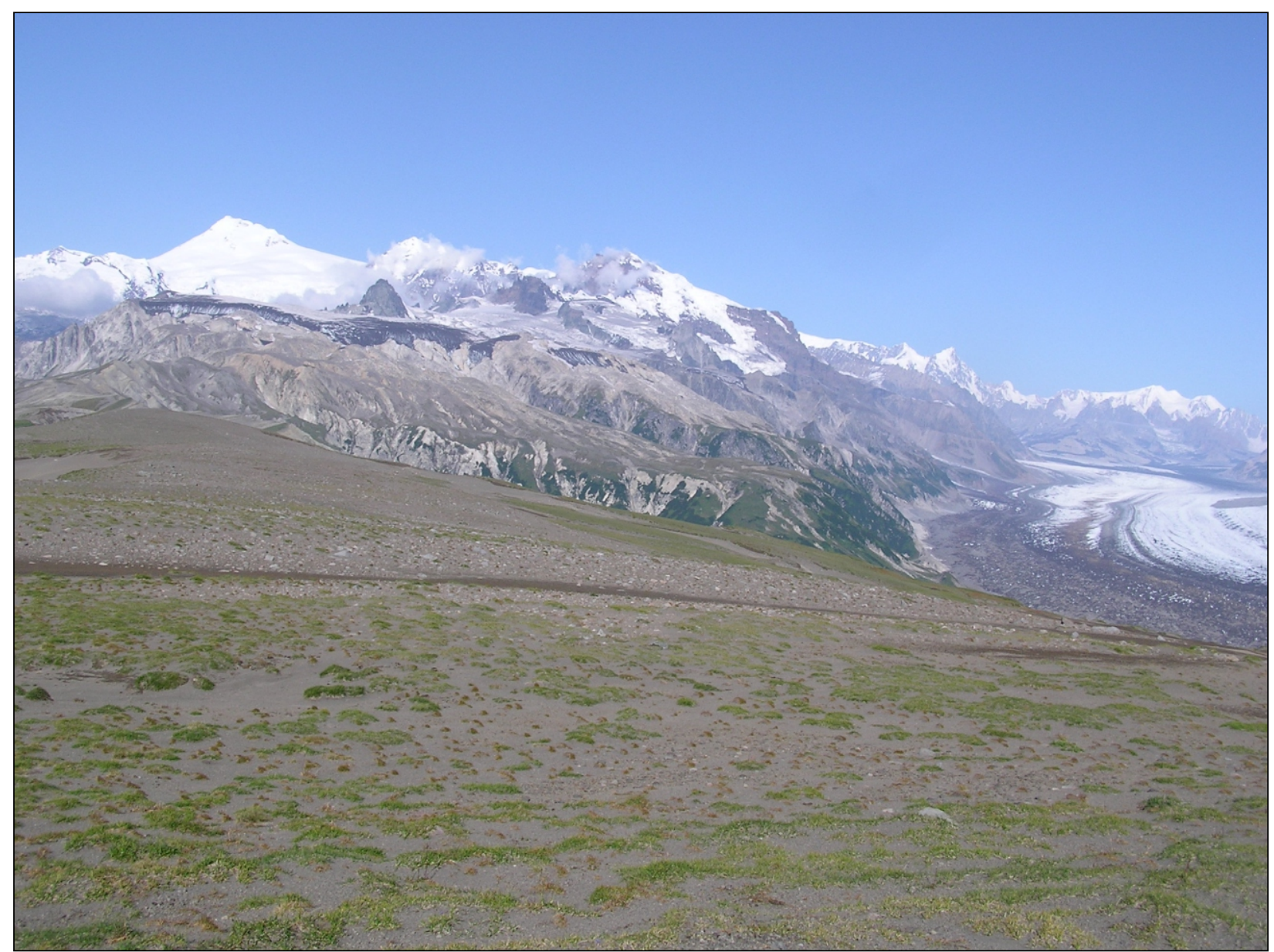

View west-northwest of volcaniclastic sediments on middle to late Pleistocene volcaniclastic plateau in foreground (N61 $\left.{ }^{\circ} 17^{\prime} 15.0^{\prime \prime}, \mathrm{W} 151^{\circ} 54^{\prime} 27.1^{\prime \prime}\right)$, which overlie conglomerates of West Foreland Formation in middleground. Sloping surfaces in middleground were scoured by Capps Glacier during the last major glaciation. Capps Glacier and the Tordrillo Mountains are in right background; Mount Spurr volcano is in left background. Photograph taken 08/10/2009 by D.S.P. Stevens.

\section{Published by}

STATE OF ALASKA

DEPARTMENT OF NATURAL RESOURCES

DIVISION OF GEOLOGICAL \& GEOPHYSICAL SURVEYS 



\section{SURFICIAL GEOLOGY OF THE TYONEK AREA, SOUTH-CENTRAL TYONEK QUADRANGLE, ALASKA}

Richard D. Reger, De Anne S.P. Stevens, and Rich D. Koehler

Report of Investigations 2015-7

State of Alaska

Department of Natural Resources

Division of Geological \& Geophysical Surveys 


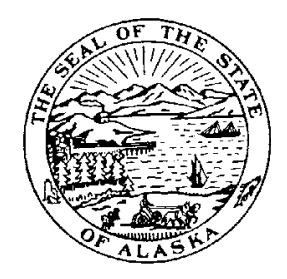

\section{STATE OF ALASKA}

Bill Walker, Governor

\section{DEPARTMENT OF NATURAL RESOURCES \\ Mark Myers, Ph.D., Commissioner}

\section{DIVISION OF GEOLOGICAL \& GEOPHYSICAL SURVEYS}

Steve Masterman, State Geologist and Director

Publications produced by the Division of Geological \& Geophysical Surveys (DGGS) are available for download from the DGGS website (www.dggs.alaska.gov). Publications on hard-copy or digital media can be examined or purchased in the Fairbanks office:

\section{Alaska Division of Geological \& Geophysical Surveys 3354 College Rd., Fairbanks, Alaska 99709-3707 \\ Phone: (907) 451-5020 Fax (907) 451-5050 \\ dggspubs@alaska.gov www.dggs.alaska.gov}

Alaska State Library

State Office Building, 8th Floor 333 Willoughby Avenue Juneau, Alaska 99811-0571

Elmer E. Rasmuson Library University of Alaska Fairbanks Fairbanks, Alaska 99775-1005
Alaska Resource Library \& Information Services (ARLIS)

3150 C Street, Suite 100

Anchorage, Alaska 99503-3982

University of Alaska Anchorage Library 3211 Providence Drive Anchorage, Alaska 99508-4614 


\section{CONTENTS}

Introduction.

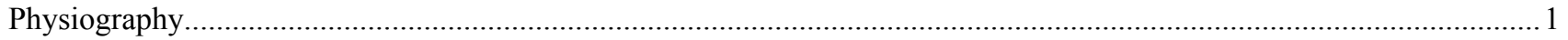

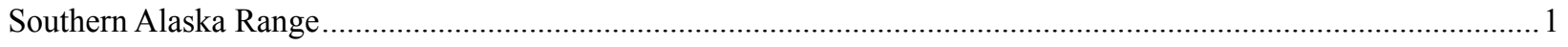

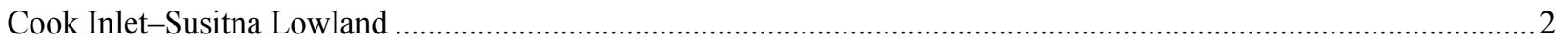

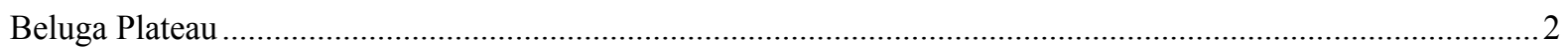

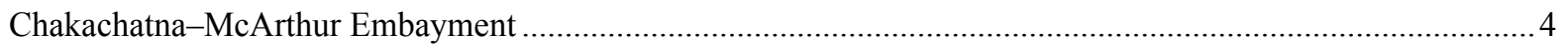

Bootlegger Cove Platform ...............................................................................................................

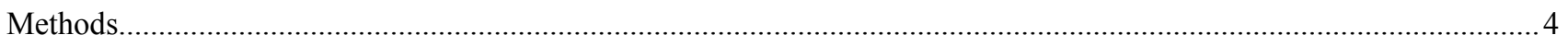

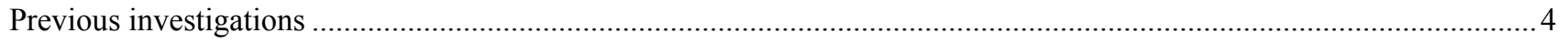

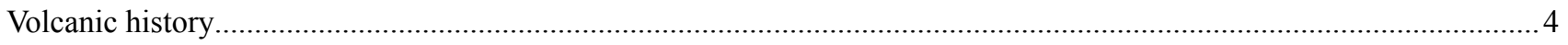

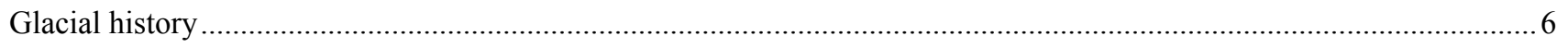

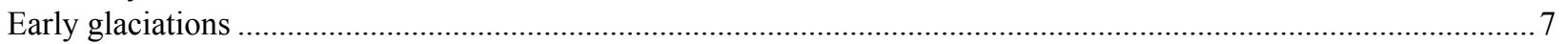

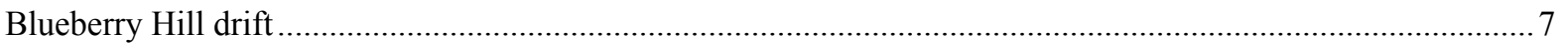

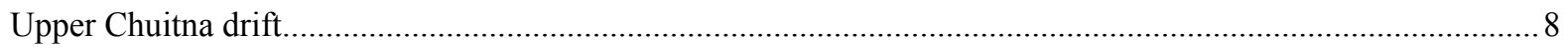

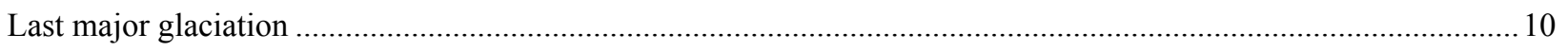

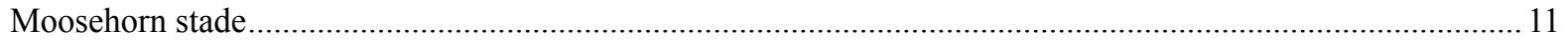

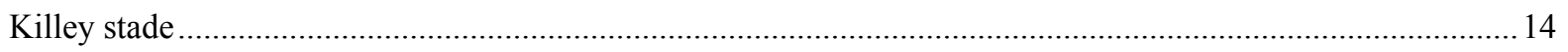

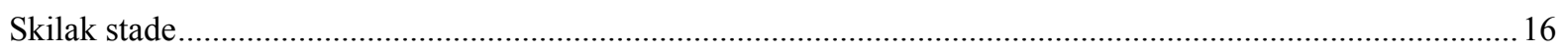

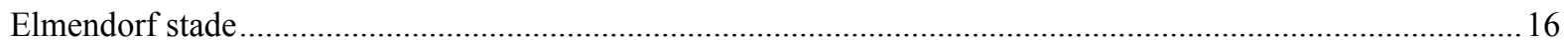

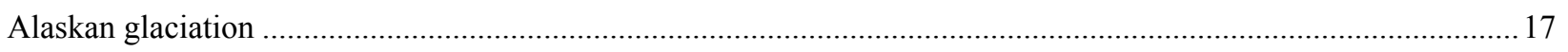

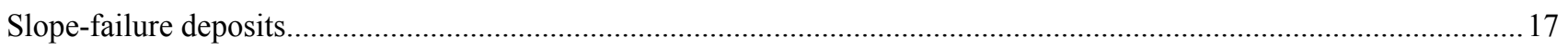

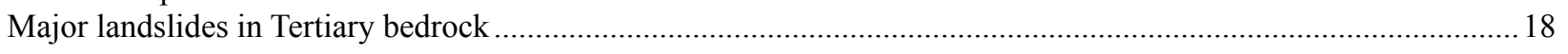

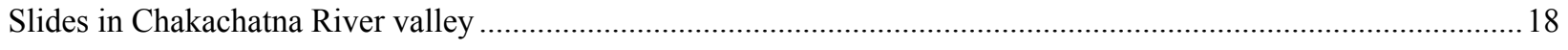

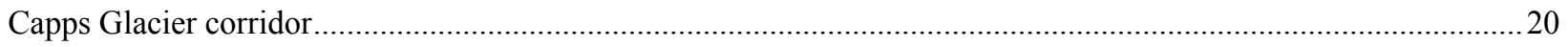

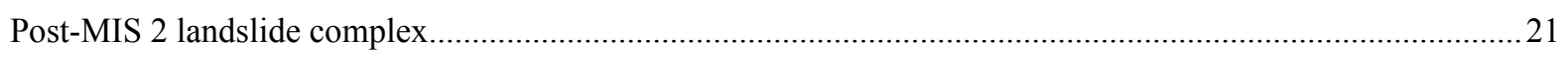

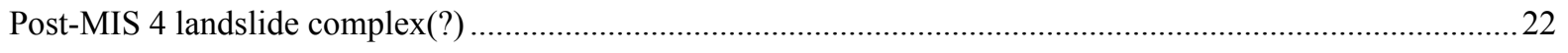

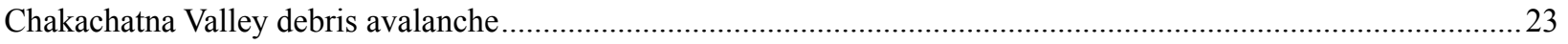

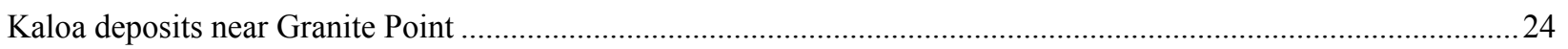

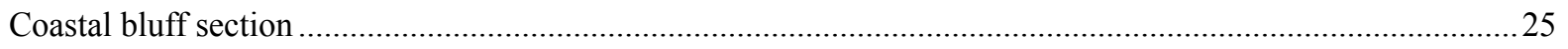

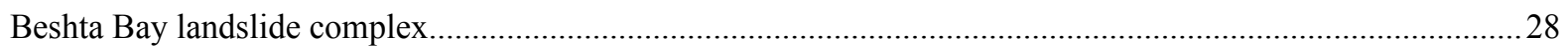

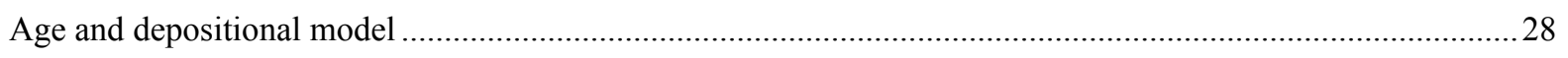

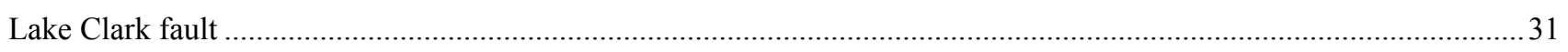

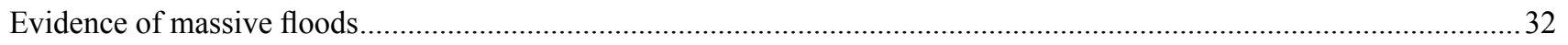

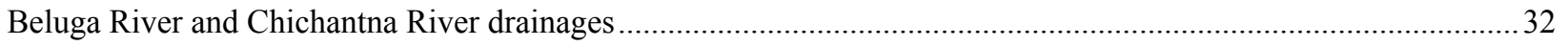



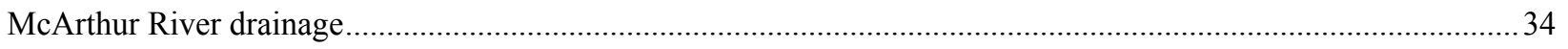

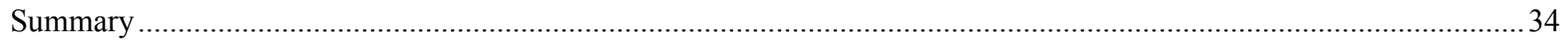

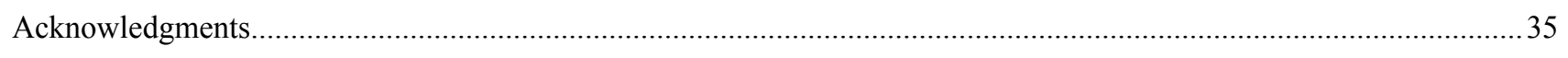

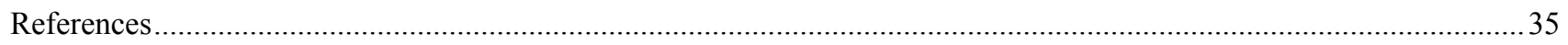




\section{FIGURES}

Figure 1. Location of Tyonek map area in northwestern Cook Inlet region, south-central Alaska...................................2

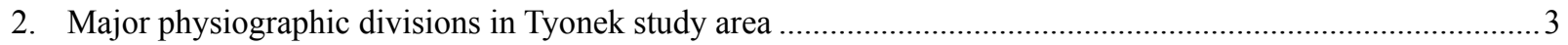

3. Principal physiographic features in study area, south-central Tyonek Quadrangle ...........................................5

4. Areas of surficial geology mapped by previous workers in the Tyonek study area........................................... 6

5. Springs eroding headward into base of volcaniclastic blanket and upper lahar deposits on northeastern

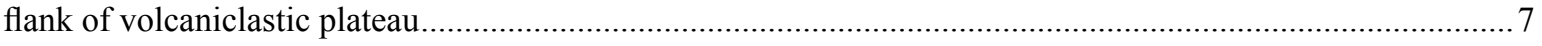

6. Large volcaniclastic erratic on Upper Chuitna drift northwest of Lone Ridge.................................................

7. Stratigraphic section exposed in test hole in Upper Chuitna drift northwest of Lone Ridge ............................ 10

8. Vertical false-color infrared aerial photograph of volcaniclastic plateau, showing locations of erratics

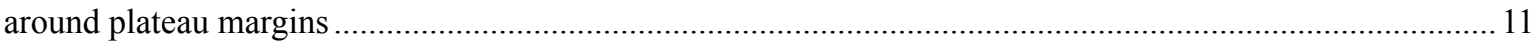

9. Large, unweathered granitic erratic in blanket of volcaniclastic sediments and erratics on northern flank of volcaniclastic plateau.

10. Scattered granitic and volcanic erratics on remnant of lateral moraine plastered against steep northeastern marginal scarp of volcaniclastic plateau .

11. Mix of weathered (rough-surfaced) granitic and unweathered (smooth-surfaced) volcanic erratics on lateral moraine along southwestern flank of volcaniclastic plateau.

12. View east of Beluga Plateau from eastern flank of volcaniclastic plateau, showing morphological contrast between high-relief lateral moraine of last major (MIS 2) glaciation and subdued ground moraine of penultimate (MIS 4) glaciation.

13. Pitted pebble conglomerate erratic of type found in both Nikolai and Nikiski moraines of Killey age.

14. Aerial view northeast of poorly drained, peat-blanketed Bootlegger Cove Platform inland from northwestern coast of Cook Inlet north of Tyonek.

15. Vertical false-color aerial photograph, showing features of complex mass displacements around volcaniclastic plateau in northwestern map area

16. Vertical false-color aerial photograph, showing two slide complexes on slope between Chichantna River and volcaniclastic plateau in north-central map area.

17. View south from southeastern flank of volcaniclastic plateau, showing granitic and volcanic erratics scattered in volcaniclastic sediments and active landslides in Tyonek Formation

18. Aerial view east-northeast of extensive area in post-MIS 4 slide complex(?) underlain by oxidized finegrained sedimentary rocks and clinkers thought to result from burning of thick Capps coal and underlying coal beds in Tyonek Formation......

19. Vertical false-color aerial photograph, showing location of Kaloa section, locations of text figures, and petroleum infrastructure in Granite Point area.

20. View northwest of coastal bluff near Granite Point, showing lines of dropstone lags formed by scouring inlet-bottom currents between rainout diamictons in glacioestuarine sediments ...........................................26

21. Sketch of section exposed northeast of pipeline in coastal bluff at Granite Point.

22. Prominent allochthonous coal bed exposed in coastal bluff $\sim 150-230$ m northeast of pipeline .28

23. Principal stratigraphic units exposed in coastal bluff $\sim 263 \mathrm{~m}$ northeast of pipeline, partially obscured by slope colluvium.

24. About $355 \mathrm{~m}$ northeast of pipeline, a 30 -cm-thick, fine-to-medium tan sand containing clasts of siderite overlies a tan-gray, complexly bedded pebbly sand, silt, and dropstone diamicton sandwiched between massive, medium-gray, dropstone-rich, rainout diamictons .

25. Complexly deformed autochthonous diamictons interlayered with sand beds in coastal bluff at southwestern end of Beshta Bay. 
26. Model showing environment beneath fluctuating tidewater glaciers and ice shelves during subinlet deposition of Kaloa sediments on western flank of growing Granite Point anticline in Granite PointBeshta Bay area.

27. Aerial view northwest of $\sim 20$-m-high Lone Ridge granitic escarpment, showing trend of Lake Clark fault between arrows.

28. Exposure of deltaic sands dipping downstream in mid-Holocene flood channel of Scarp Creek, northeastern map area

\section{TABLES}

Table 1. Relation of Cook Inlet glacial chronology and marine-isotope stages to local moraines and deposits in Tyonek map area and northwestern Kenai Peninsula.

2. Compositions of pebbles $(n=144)$ collected from test pit in Upper Chuitna till northwest of Lone Ridge..... 10

3. Summary of chronologically significant radiocarbon dates associated with late Quaternary deposits in Tyonek area

4. Total stratigraphic thicknesses and lithologic contents in four boreholes in Tyonek Formation, Capps and Chuitna coal fields (modified from Odum and others, 1986) (sheet 1) 



\title{
SURFICIAL GEOLOGY OF THE TYONEK AREA, SOUTH-CENTRAL TYONEK QUADRANGLE, ALASKA
}

\author{
Richard D. Reger ${ }^{1}$, De Anne S.P. Stevens ${ }^{2}$, and Rich D. Koehler ${ }^{2}$
}

\begin{abstract}
Glaciers invaded the Tyonek area several times during the Quaternary Period. Subdued Blueberry Hill drift (MIS 6?) is locally preserved near Lone Ridge, outside the limits of the Upper Chuitna moraine (MIS 4). Lack of glacial erratics on the high-level volcaniclastic plateau between Tyonek and Mount Spurr volcano and the discontinuous ring of granitic and volcanic erratics along the plateau edge that are related to the penultimate glaciation demonstrate that the volcaniclastic plateau has not been glaciated during the late Pleistocene. Below the level of the penultimate (MIS 4) glaciation, high-relief moraines of the last major (MIS 2) glaciation document ice expansions from the Capps Glacier trough, the southern Susitna Lowland, and the Chakachatna-McArthur Embayment. Comparison of till-pebble compositions supports correlation of MIS 2 moraines in the Tyonek map area with moraines of the Naptowne glaciation near Nikiski on the northwestern Kenai Peninsula. Small moraines close to modern glacier margins document minor Neoglacial and Little Ice Age glacier advances during the Holocene.

Major landslides in the West Foreland (middle Eocene) and Tyonek (early Oligocene-middle Miocene) Formations are encroaching on the southwestern, northeastern, and eastern margins of the high-level volcaniclastic plateau. Physiographic relations indicate that currently active landsliding began after the last major glaciation and an older generation of landslides probably postdates the penultimate glaciation. An incipient, north-striking trellis drainage system on the volcaniclastic plateau could be evidence that the plateau is spreading. A large, mid-Holocene volcanic-debris avalanche resulted from collapse of the southern flank of the Mt. Spurr edifice. Reinterpretation of the Granite Point bluff section demonstrates that the Kaloa deposits there record subestuarine landslides and debris flows late in the last major glaciation, not evidence of multiple Miocene glaciations as previously proposed.

Physiographic evidence demonstrates that the Lake Clark fault has not produced surface ruptures for at least $30 \mathrm{ka}$, probably for at least $60 \mathrm{ka}$, and possibly not for $130 \mathrm{ka}$.

Physiographic and stratigraphic evidence indicates that collossal outburst flooding periodically occurred in the Beluga River during the past $\sim 17$ ka, when glacier-impounded lakes suddenly drained; massive jökulhlaups continue to episodically inundate that drainage. Temporary damming of the Chakachatna River valley by the massive mid-Holocene volcanic-debris avalanche from the southern flank of the Mt. Spurr massif ultimately produced a massive outburst flood in that drainage. In the near future it is unlikely that another sector collapse or thickening and advance of glaciers on the southern flank of the Mt. Spurr massif will occur to dam the eastern end of Lake Chakachamna and again produce outburst flooding down the Chakachatna River.
\end{abstract}

\section{INTRODUCTION}

The Tyonek area in the northwestern Cook Inlet trough (fig. 1) is rich in petroleum, coal, geothermal, aggregate, and timber resources, but the detailed geologic mapping necessary for planning future resource development exists only in part of the area. The purpose of our surficial-geology mapping is to provide important detailed information for the area to supplement cooperative bedrock investigations by the Alaska Division of Geological \& Geophysical Surveys (DGGS), the U.S. Geological Survey (USGS), and university geologists. Our studies began with a brief reconnaissance of the controversial Kaloa section at Granite Point in late August 2007 (Reger, 2009). That local study was followed by field investigations in the map area during the late summers of 2008-2010.

\section{PHYSIOGRAPHY}

The study area straddles the boundary between two major physiographic provinces in south-central Alaska: the Southern Alaska Range and the Cook Inlet-Susitna Lowland (Wahrhaftig, 1965).

\section{SOUTHERN ALASKA RANGE}

Rugged, mountain topography is characteristic of the southern Alaska Range, where alpine glaciation has reduced uplands and carved deep valleys, many still containing active glaciers, in crystalline batholithic and associated metasedimentary and metavolcanic bedrock (Magoon and others, 1976; Reed and others, 1983). Three mountain clusters are part of the southern Alaska Range in the map area. The Neacola and Chigmit mountains, which reach peak elevations

\footnotetext{
${ }^{1}$ Reger's Geologic Consulting, PO Box 3326, Soldtona, AK 99669, rdreger@acsalaska.net

${ }^{2}$ Alaska Division of Geological \& Geophysical Surveys, 3354 College Road, Fairbanks, AK 99709-3707
} 
from 2,800 to $5,500 \mathrm{ft}$ ( 848 to $1,667 \mathrm{~m}$ ), are represented by the rugged high granitic terrane in the southwestern corner of the study area (fig. 2). Basement bedrock there comprises granitic intrusive rocks of Cretaceous and Tertiary ages (Magoon and others, 1976). The Tordrillo Mountains occupy the northwestern corner of the Tyonek study area. That complex highland terrane is composed of glacially scoured granitic batholiths of Cretaceous and Tertiary ages with associated Juro-Cretaceous metasedimentary and metavolcanic rocks. Built on this basement assemblage is the Mount Spurr volcanic complex of late Cenozoic age. Mount Spurr volcano, at $11,070 \mathrm{ft}(3,355 \mathrm{~m})$ elevation, is $\sim 4.8 \mathrm{~km}$ south-southwest of the northwest corner of the study area (fig. 1). Geologic studies indicate that Mount Spurr was active during the Quaternary Period, depositing volcaniclastic and tephra deposits in the map area (Riehle, 1985; Waythomas and Nye, 2002; Herriott and others, 2014). The Crater Peak satellite vent most recently erupted in 1953 and 1992 (Juhle and Coulter, 1955; Keith, 1995).

\section{COOK INLET-SUSITNA LOWLAND}

The Cook Inlet-Susitna Lowland physiographic province, a large northeast-trending trough between the Kenai-Chugach and Talkeetna mountains and the Southern Alaska Range (Wahrhaftig, 1965), contains a thick fill of economically important petroliferous and coal-bearing clastic sedimentary rocks of Tertiary age (Magoon and others, 1976). These weakly to well-consolidated rocks are overlain by a thin, discontinuous cover of Quaternary glacial and associated sediments. Most of the map area is in the Cook Inlet-Susitna Lowland, which is roughly divided in half by the Beluga Plateau and the Chakachatna-McArthur Embayment, and the Bootlegger Cove Platform is represented by two small areas adjacent to the Cook Inlet coast (fig. 2).

\section{Beluga Plateau}

The Beluga Plateau slopes generally eastward from $\sim 3,000 \mathrm{ft}(915 \mathrm{~m})$ elevation near the eastern margin of the Tordrillo Mountains to Cook Inlet and is bounded on the

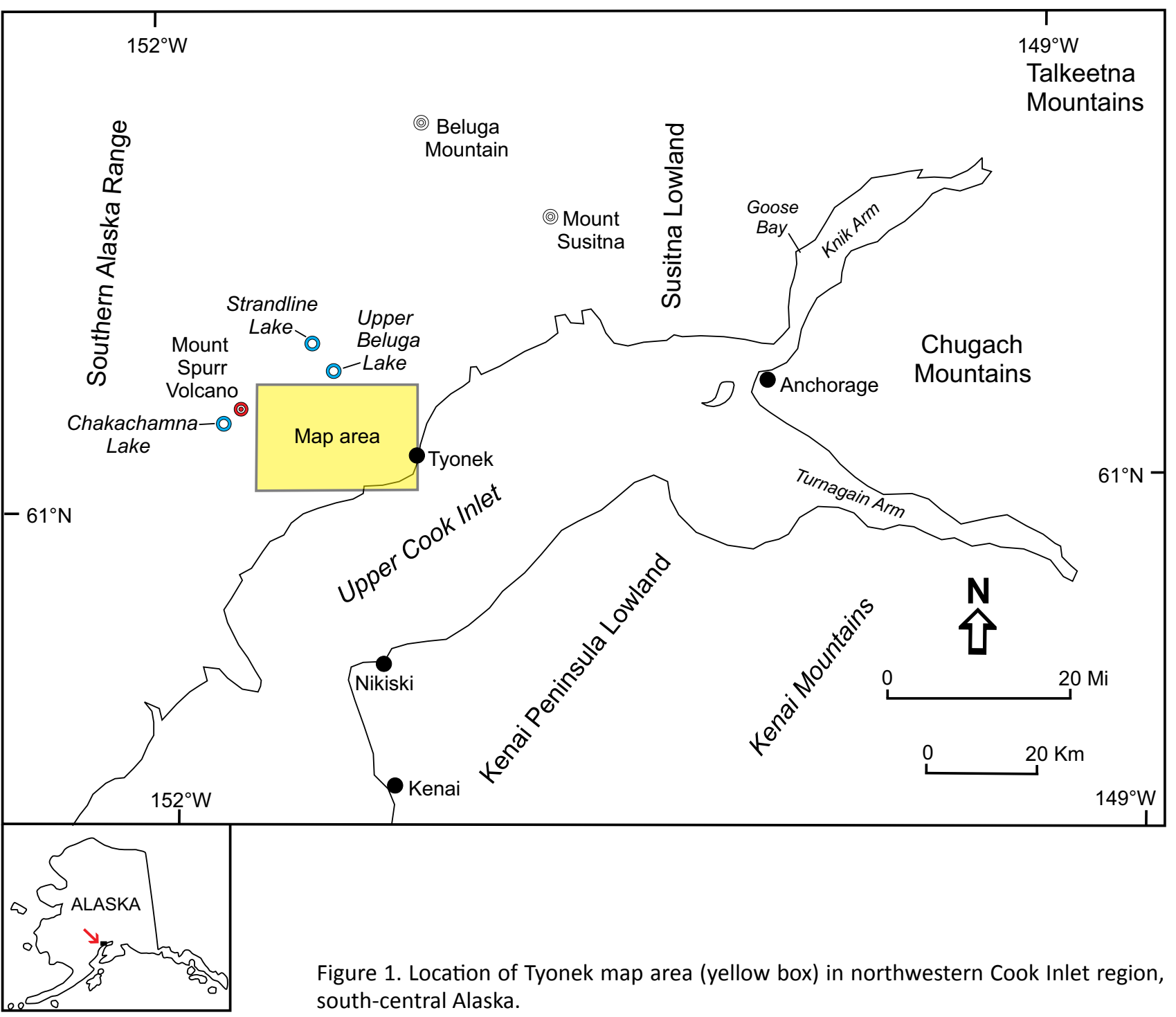

south-central Alaska. 


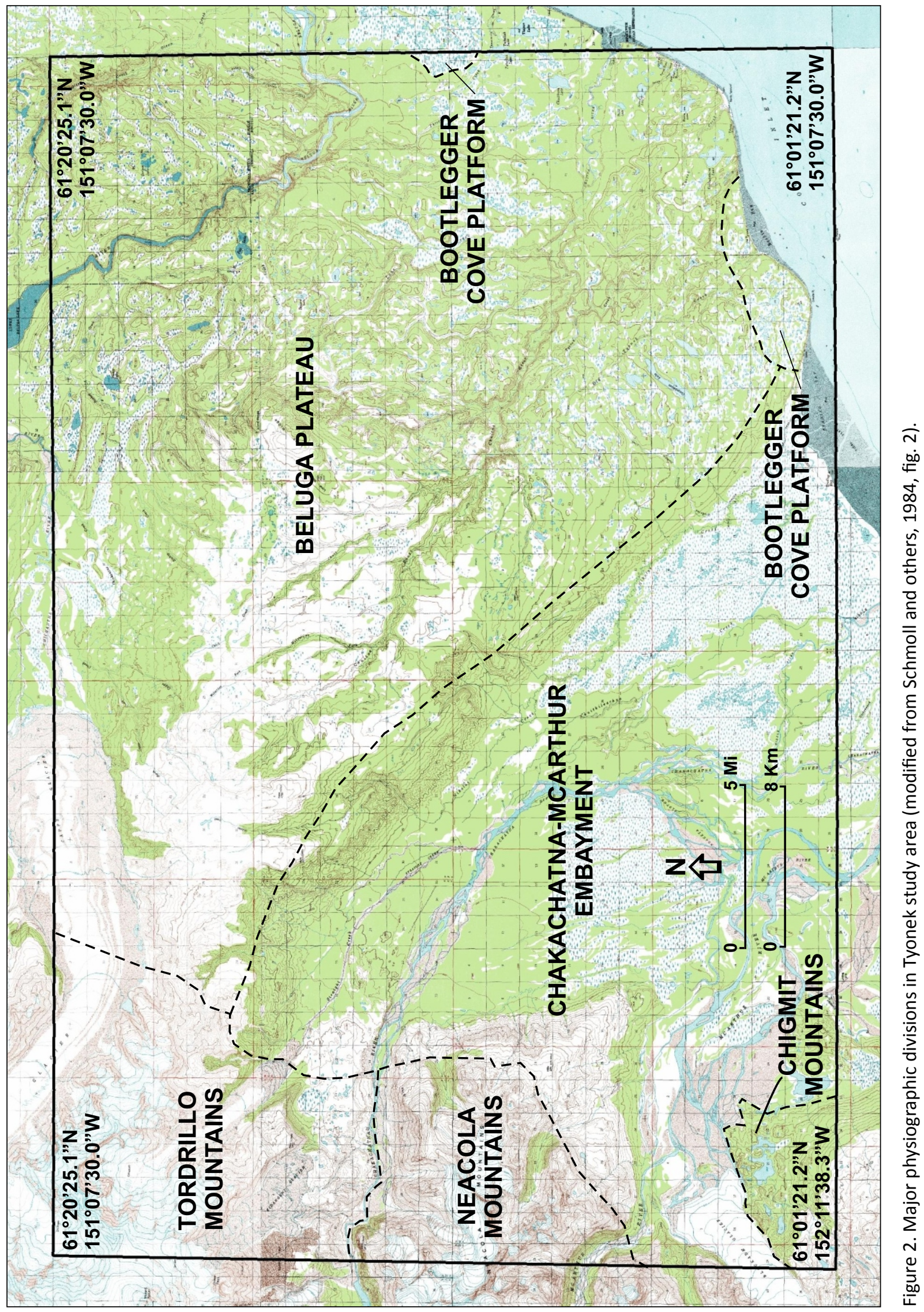


southeast by the Chakachatna-McArthur Embayment, which was a major corridor for ice spreading into the Cook Inlet lowland from the Chakachatna and McArthur river valleys (figs. 2, 3). The Beluga Plateau is underlain by a complex wedge of petroleum- and coal-bearing clastic sedimentary rocks of Tertiary age that generally thicken eastward (Magoon and others, 1976) ${ }^{3}$. In the western Beluga Plateau a thick sequence of volcaniclastic deposits laid down by middle to late Pleistocene eruptions of Mount Spurr forms a conspicuous high-level volcaniclastic plateau capping the Tertiary sedimentary section (Herriott and others, 2011, 2014) (fig. 3). This volcaniclastic plateau is an isolated remnant that was cut off from the main Mount Spurr volcanic complex by erosion (Herriott and others, 2014). The northeastern quarter of the volcaniclastic plateau displays an incipient network of trellis drainages, and the area of the plateau is being reduced along its northeastern, eastern, and southwestern margins by extensive landslides founded in the underlying slide-prone Tertiary bedrock (fig. 3). Most of the Beluga Plateau is covered by a complex of glacial moraines related to ice streams emanating from both the Chakachatna-McArthur Embayment and the Capps Glacier corridor during the last major and penultimate glaciations. The morainal complex is displaced by extensive ancient and active landslides (Schmoll and others, 1981). The northern Beluga Plateau is drained by the Beluga River, a large glacial-meltwater stream with a history of outburst flooding (Post and Mayo, 1971).

\section{Chakachatna-McArthur Embayment}

The Chakachatna-McArthur Embayment is separated from the Beluga Plateau by a steep escarpment scoured into landslide-prone Tertiary sedimentary rocks by a compound glacial lobe that formerly occupied the Chakachatna and McArthur river valleys (fig. 3). The embayment contains a complex sediment fill. Holocene moraines were built by Blockade Glacier and by glacier ice draining the southeastern flank of Mount Spurr (fig. 3, sheet 1); glaciofluvial sediments related to these ice advances and periodic floods released by failures of volcanic-debris dams near the outlet of Lake Chakachamna (Waythomas, 2001) form most of the large Chakachatna alluvial fan complex below $\sim 500 \mathrm{ft}(\sim 150 \mathrm{~m})$ elevation. The distal fringe of the broad alluvial-fan complex includes fine-grained deltaic sediments of the prograding fan (Riehle and Emmel, 1980). A series of short beach ridges in the eastern corner of the alluvial fan west of Granite Point likely documents gradual uplift by isostatic rebound or tectonism (fig. 3).

\section{Bootlegger Cove Platform}

Two areas of the Bootlegger Cove Platform are recognized along the eastern margin of the Beluga Plateau, where there are glacioestuarine and estuarine deposits attributed to the Bootlegger Cove Formation of late Quaternary age
(Schmoll and Yehle, 1983, 1986; Reger, 2009) (fig. 2). North of lower Threemile Creek, a broad peaty wetland forms the coastal plain. Numerous discontinuous, linear beach ridges, now heavily vegetated and barely recognizable, trend across this coastal plain parallel to the modern coast on the Bootlegger Cove Platform north of Tyonek.

\section{METHODS}

Surficial geology in the $2,220 \mathrm{~km}^{2}$ study area was initially mapped by interpreting 1:65,000-scale false-color infrared aerial photographs taken in August 1978 and plotting unit boundaries on acetate overlays. Pertinent information from previous geologic reports was incorporated throughout our investigations. Verification or modification of photo mapping was accomplished during the 2007-2010 field seasons, when exposures were examined, map units were described, and samples collected for analyses. Following orthorectification of the aerial photographs and attached acetate overlays, unit boundaries were digitized onscreen using ArcGIS, glacier ice extents were updated using 1999-2003 Landsat satellite imagery, and the surficial geology map was prepared (sheet 1).

\section{PREVIOUS INVESTIGATIONS}

In parts of the Tyonek study area where mining of the Beluga coal field and related resource-development activities are anticipated, late Quaternary deposits were previously mapped at scales of $1: 31,680$ and $1: 63,360$ by the interpretation of 1952, 1953, and 1957 black-and-white aerial photographs (Schmoll, Yehle and Gardner, 1981; Yehle and others, 1983a, b; Schmoll and Yehle, 1987) (fig. 4). Because those authors preferred to define their glacial map units using informal local moraine names (Schmoll and others, 1984; Schmoll and Yehle, 1986, 1987) rather than the regional terminology proposed by Karlstrom (1964) for the Cook Inlet glacial chronology ${ }^{4}$, questions remained about the relations of surficial deposits in the study area to surficial deposits elsewhere in the Cook Inlet region.

\section{VOLCANIC HISTORY}

In the volcaniclastic plateau in the northwestern Tyonek study area, the middle Pleistocene history of ancestral Mount Spurr is documented by unconsolidated to well-indurated lahar deposits composed of sediments laid down by hyperconcentrated flows and debris flows. Interbedded with the fine-grained lahar deposits are fluvial sandstones and conglomerates that crop out in the walls of gullies and marginal slopes of the volcaniclastic plateau between Capps Glacier and Straight Creek (fig. 3). The volcaniclastic sequence is estimated to be as thick as $275 \mathrm{~m}$ and unconformably overlies the West Foreland and Tyonek Formations of Tertiary age

\footnotetext{
${ }^{3}$ An exception is Lone Ridge, a local highland composed of a small granitic intrusion of Cretaceous and Tertiary age, which stands conspicuously above the plateau surface (Magoon and others, 1976).

${ }^{4}$ Correlations of glacial deposits in the Cook Inlet region (particularly for older glaciations) are complicated by the long distances involved, lack of intervening stratigraphic evidence, postglacial destruction of physiographic and stratigraphic evidence, tectonic and isostatic displacements, and few reliable constraining dates (Reger and Updike, 1983; Schmoll and others, 1999).
} 


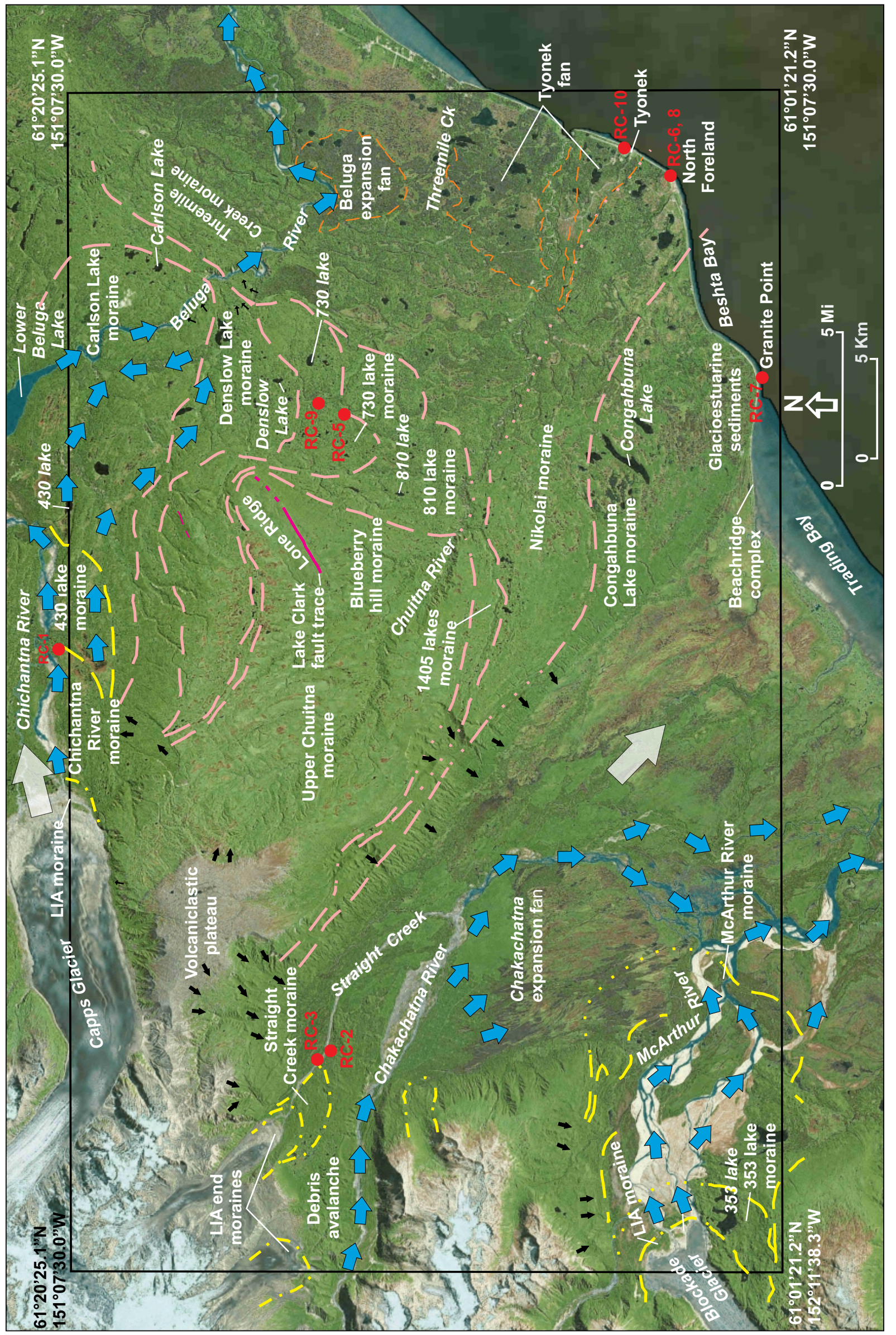

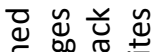
등 웅 $\frac{0}{9}$ 둥 들 政 茄额 列 政 3 중 은

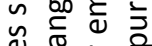
空 준.

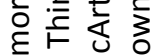
व $\sum_{0} \frac{0}{n}$

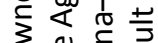
응 品

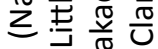
든 든

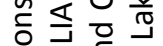
品 उ茪 흥 步 $4.5 \dot{0}$ 응 है

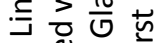

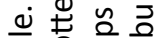
응 응 응 늫

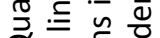
월 을 둥 (3)

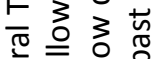
눙 षे

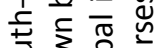
完 刃ำ 它. 政的 흘 흥 फे $\varepsilon$. 0 에 政 우워 造 온

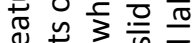
닐 兄寻 흥 客元 bo d v 눈

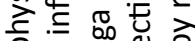
은 흥 ब。 उ웡 항 i

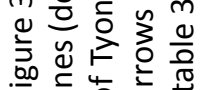


(Herriott and others, 2011, 2014). Bedding in the sequence is generally subhorizontal, but beds locally dip as steeply as vertical, and vertical to low-angle faults are present. The incipient trellis drainage pattern on the northeastern volcanic plateau is probably controlled by parallel vertical joints and small-displacement, vertical faults in the volcaniclastic bedrock. Although Yehle and others (1983a) speculated that some of the beds in the volcaniclastic sequence could be of glacial origin, we found no evidence of interstratified glacial drift. Capping this thick sequence are 1-6 m of medium-gray sand and granules thought to be derived from the underlying lahar deposits. These are being reworked by fluvial, eolian, and slope processes, spring sapping, and nivation (fig. 5). A 1-2-m-thick layer of loess, composed primarily of finegrained Holocene tephras, blankets the volcaniclastic plateau.

Holocene activity of the Spurr volcanic complex is manifested in the western map area by proximal lahar deposits on lower slopes of the complex and by a large debris-avalanche deposit that temporarily dammed the Chakachatna River valley during a mid-Holocene massive sector collapse of the Mount Spurr edifice (Waythomas, 2007) (sheet 1). A large expansion fan was built downvalley from the debrisavalanche deposit during several cycles of flooding released by failures of temporary volcanic-debris dams that periodically blocked the Chakachatna River valley near the outlet of Lake Chakachamna during Holocene eruptions of the Spurr volcanic complex (Meyer and Trabant, 1995; Waythomas, 2001) (fig. 3). Elsewhere in the study area, numerous thin tephras in the loess cover document periodic eruptions of Mount Spurr, including most recently the Crater Peak satellite vent (Riehle, 1985; Waythomas and Nye, 2002).

\section{GLACIAL HISTORY}

Schmoll and Yehle (1987) identified three main sources for glaciers that invaded the Tyonek area during past glaciations. Erratics in glacial deposits derived from northern and northwestern sources, including the Tordrillo Mountains, the Susitna highland west of Beluga Mountain, and the Beluga Lake-Capps Glacier corridor are composed of granitic and metasedimentary lithologies of Mesozoic age and granitic, volcanic, and sedimentary rocks of Tertiary and Quaternary ages. Glaciers from the northeast transported granitic rocks of Cretaceous and Tertiary ages from intrusive bodies in the Mount Susitna area as well as metasedimentary rocks of Mesozoic age and sedimentary rocks of Tertiary age from the Susitna Lowland. Glaciers from the Chakachatna-McArthur Embayment west and southwest of the map area carried volcanic rocks from the southern flank of the Mount Spurr complex and granitic rocks of Mesozoic and Tertiary ages from the Chigmit and Neacola mountains and the Alaska Range to the west.

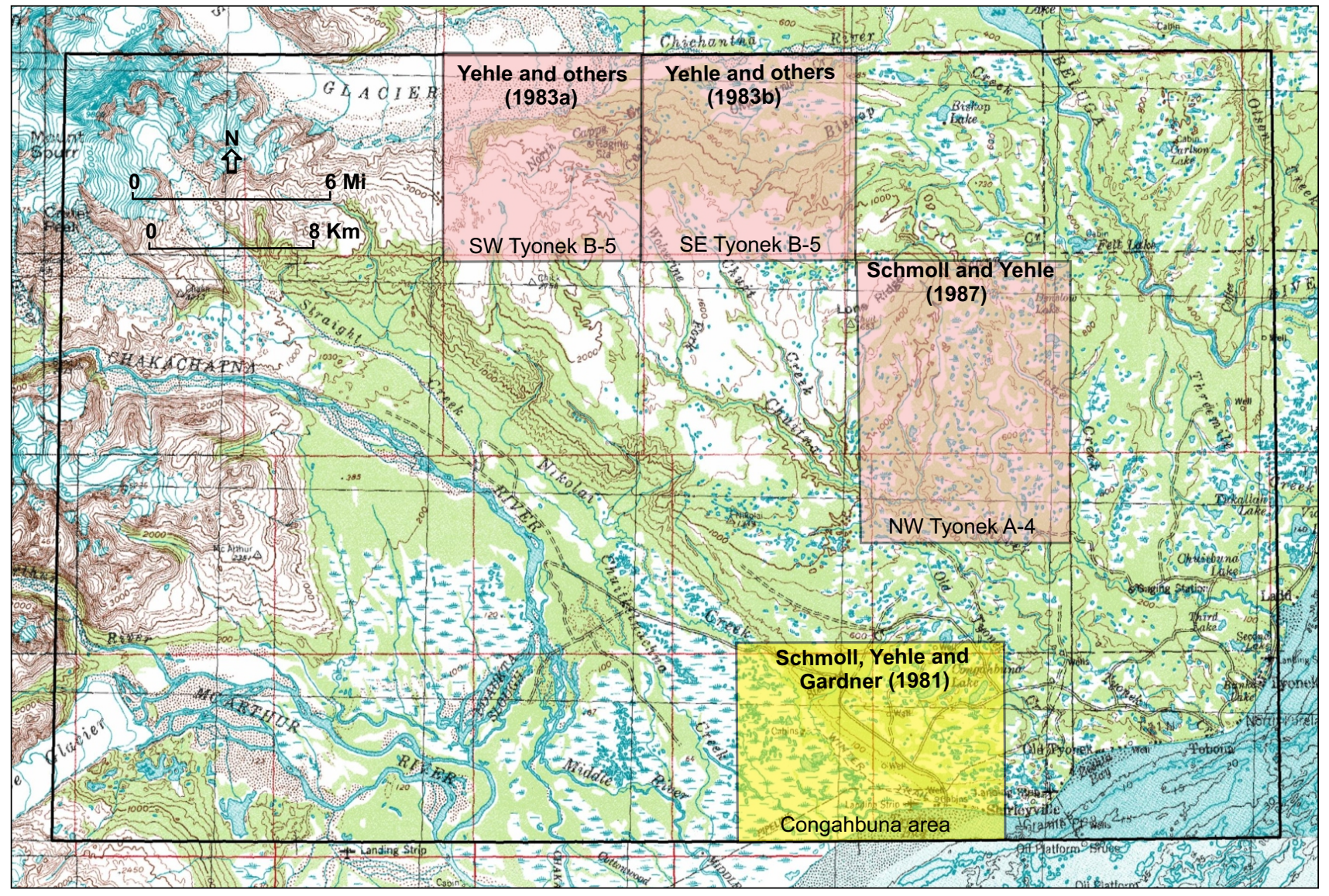

Figure 4. Areas of surficial geology mapped by previous workers in the Tyonek study area. Pink indicates maps published at 1:31,680 scale; yellow indicates map published at 1:63,360 scale. 
During the last major glaciation the map area was invaded by the massive Cordilleran ice sheet, which spread eastward and southward into the Cook Inlet trough from sources in the Alaska Range to the west and north, respectively. Following the climax of this glaciation 23 cal kya, the glacier complex thinned and ice from individual lobes fluctuated on the Beluga Plateau, in the Chakachatna-McArthur Embayment, and on the Bootlegger Cove Platform (Schmoll and Yehle, 1983, 1986, 1987; Reger, 2009). Most glacial, glacioestuarine, and estuarine deposits preserved in the coastal lowland near northwestern Cook Inlet date from late glacial events and the Holocene (Reger, 2009).

Based on their interpretations of geomorphic relations and available radiocarbon evidence, Schmoll and others (1984) and Schmoll and Yehle $(1986,1987)$ proposed a morainal chronology for the map area (table 1). Our investigations provide evidence for a similar, although slightly different, glacial chronology. Except for substituting the Carlson Lake moraine for the inner part of the Denslow Lake moraine and adding the Congahbuna Lake moraine, in this report we generally adopt the informal morainal terminology developed by Schmoll and Yehle for the map area (table 1). The Upper Chuitna, Denslow Lake, Carlson Lake, Congahbuna Lake, and Threemile Creek moraines are named after local features (fig. 3). However, names of most other moraines are based on the elevations (in feet) of lakes on the particular moraines. An exception is the Blueberry Hill moraine, named after a local airstrip used by bush pilots (Schmoll and Yehle, 1987).

\section{EARLY GLACIATIONS}

Deposits left by glaciations older than the last ice age are considerably modified by surface processes, including solifluction, frost creep, eolian deposition, and stream erosion. In the case of the oldest recognized glaciation, the morphology of moraines is modified to a degree that their glacial origin is difficult to recognize. Elsewhere, in slightly younger moraines, morainal ridges and drumlin-like features are recognizable but subdued. Kettles are rounded and partially filled with slopewash, eolian sediments, and peat. Surface lags contain fresh to slightly weathered erratics. Headward erosion by streams has considerably dissected lowland deposits of these oldest glaciations. On lower sideslopes, moraine margins and sideglacial drainage channels are locally obliterated by encroaching slope deposits.

\section{Blueberry Hill drift}

In the vicinity of Lone Ridge on the Beluga Plateau between the Beluga and Chuitna rivers, Schmoll and others



Figure 5. Springs eroding headward into base of volcaniclastic blanket and upper lahar deposits on northeastern flank of volcaniclastic plateau (N61¹7'00.7', W15152'57.6”'). Geologist provides scale. Photograph taken 08/10/2009 by R.D. Reger. 
Table 1. Relation of Cook Inlet glacial chronology and marine-isotope stages to local moraines and deposits in Tyonek map area and northwestern Kenai Peninsula.

\begin{tabular}{|c|c|c|c|c|c|c|}
\hline \multirow[t]{2}{*}{ Glaciation } & \multirow[t]{2}{*}{$\begin{array}{l}\text { Marine } \\
\text { isotope } \\
\text { stage }\end{array}$} & \multicolumn{2}{|c|}{$\begin{array}{l}\text { Cook Inlet } \\
\text { glacial chronology }\end{array}$} & \multirow{2}{*}{$\begin{array}{l}\begin{array}{c}\text { Northwestern } \\
\text { Kenai } \\
\text { Peninsula }\end{array} \\
\text { Reger and } \\
\text { others } \\
\text { (2007) }\end{array}$} & \multicolumn{2}{|c|}{ Tyonek map area } \\
\hline & & $\begin{array}{l}\text { Karlstrom } \\
(1964)\end{array}$ & $\begin{array}{c}\text { Reger and } \\
\text { Pinney (1996, } \\
\text { 1997); Reger } \\
\text { and others } \\
\text { (2007) }\end{array}$ & & $\begin{array}{l}\text { Schmoll and } \\
\text { others (1984); } \\
\text { Schmoll and } \\
\text { Yehle (1986) }\end{array}$ & Reger (2009); this study \\
\hline Alaskan & MIS 1 & Alaskan & Alaskan & - & - & $\begin{array}{l}430 \text { lake, Chichantna } \\
\text { River, } 353 \text { lake, and } \\
\text { Straight Creek moraines }\end{array}$ \\
\hline \multirow{4}{*}{ Naptowne } & \multirow{4}{*}{ MIS 2} & $\begin{array}{l}\text { Tanya } \\
\text { stade }\end{array}$ & $\begin{array}{l}\text { Elmendorf } \\
\text { stade }\end{array}$ & $\begin{array}{l}\text { Coastal bluff } \\
\text { recession }\end{array}$ & $\begin{array}{l}\text { Inner Denslow } \\
\text { Lake moraine }\end{array}$ & $\begin{array}{l}\text { Carlson Lake moraine; } \\
\text { Koala glacioestuarine and } \\
\text { estuarine deposits }\end{array}$ \\
\hline & & $\begin{array}{l}\text { Skilak } \\
\text { stade }\end{array}$ & Skilak stade & $\begin{array}{l}15 \text { m coastal } \\
\text { terrace }\end{array}$ & $\begin{array}{l}\text { Denslow Lake } \\
\text { moraine }\end{array}$ & $\begin{array}{l}\text { Denslow Lake and } \\
\text { Congahbuna Lake } \\
\text { moraines }\end{array}$ \\
\hline & & Killey stade & Killey stade & $\begin{array}{l}\text { Nikiski end } \\
\text { moraines and } \\
\text { braidplain }\end{array}$ & $\begin{array}{l}730 \text { lake, Nikolai, } \\
\text { and } 810 \text { lake } \\
\text { moraines }\end{array}$ & $\begin{array}{l}\text { Beluga expansion fan; } 730 \\
\text { lake and Threemile Creek } \\
\text { moraines; Tyonek } \\
\text { outwash fan; Nikolai } \\
\text { moraine }\end{array}$ \\
\hline & & $\begin{array}{l}\text { Moosehor } \\
\text { n stade }\end{array}$ & $\begin{array}{l}\text { Moosehorn } \\
\text { stade }\end{array}$ & $\begin{array}{l}\text { Glaciomarine } \\
\text { deposits at } \\
\text { Kenai }\end{array}$ & $\begin{array}{l}1405 \text { lakes and } \\
\text { Threemile Creek } \\
\text { moraines }\end{array}$ & $\begin{array}{l}810 \text { lake and } 1405 \text { lakes } \\
\text { moraines }\end{array}$ \\
\hline $\begin{array}{l}\text { Pre- } \\
\text { Naptowne } \\
\text { glaciations }\end{array}$ & $\begin{array}{l}\text { MIS } 4 \\
\text { and } 6\end{array}$ & $\begin{array}{l}\text { Pre- } \\
\text { Naptowne } \\
\text { glaciations }\end{array}$ & $\begin{array}{l}\text { Pre- } \\
\text { Naptowne } \\
\text { glaciations }\end{array}$ & - & $\begin{array}{l}\text { Blueberry hill } \\
\text { moraine from } \\
\text { north; Upper } \\
\text { Chuitna moraine } \\
\text { from northwest }\end{array}$ & $\begin{array}{l}\text { Upper Chuitna moraine } \\
\text { (high-level erratics) (MIS } \\
\text { 4); Blueberry hill moraine } \\
\text { (MIS 6?) }\end{array}$ \\
\hline
\end{tabular}

(1984) and Schmoll and Yehle (1986) recognized two moraines dating older than the last major glaciation and suggested that the Upper Chuitna moraine could predate their Blueberry Hill moraine (table 1). Because the Blueberry Hill moraine is preserved on or south of Lone Ridge, they reasoned that it was likely deposited by ice flowing southward from sources east and west of Mount Susitna, northeast of our study area (fig. 1). Our mapping indicates that a small patch of featureless Blueberry Hill moraine is preserved on and southeast of Lone Ridge and is crosscut by a subtle lateral moraine of the Upper Chuitna glaciation, and so could be older (sheet 1). However, another viable option is that both moraines were deposited during the same glaciation and the cross-cutting relation results from nonsynchronous lobe fluctuations. We tentatively assign drift of the Blueberry Hill moraine to MIS 6 of the marine-isotope time scale (table 1).

\section{Upper Chuitna drift}

The lowland between Lone Ridge and the volcaniclastic plateau is surrounded by high-relief lateral moraines composed of drift of the latest major glaciation and is underlain by drift of the Upper Chuitna moraine, which Schmoll and others (1984) suggested is derived from the Tordrillo Mountains.
Evidence that at least part of the drift sheet is derived from the western Beluga Plateau is provided by a large, conspicuous, volcaniclastic erratic perched on the northeastern flank of a low drumlin-like ridge northwest of Lone Ridge (sheet 1), the only exceptionally large erratic we found on the Upper Chuitna moraine during an extensive helicopter survey of the lowland.

The large erratic stands $5 \mathrm{~m}$ above the surrounding ground surface and has a very rough surface consisting of pebbles, cobbles, and blocks of andesitic composition with a medium sand matrix (fig. 6). The material is clast supported, and we estimate that the dominant clast size is $5-10 \mathrm{~cm}$. Several clasts were loose on the surface of the feature or were strewn on the surrounding ground surface, and a low ring of debris derived from the erratic had been built around the base of the feature. We dug a 1-m-deep pit into this small ring and encountered scattered, rounded to subrounded pebbles and cobbles of crystal-rich, vesicular to nonvesicular andesite in a matrix of medium-dark brown, reworked loamy loess with interbeds of tephra ${ }^{5}$. The volcanic clasts have thin weathering rinds and still retain their integrity. Based on the composition of the erratic and the weak postglacial weathering, we suggest that the erratic was plucked from a block flow on the

\footnotetext{
${ }^{5}$ We suggest that the silty matrix of the low ring was washed from the surface of the large erratic.
} 


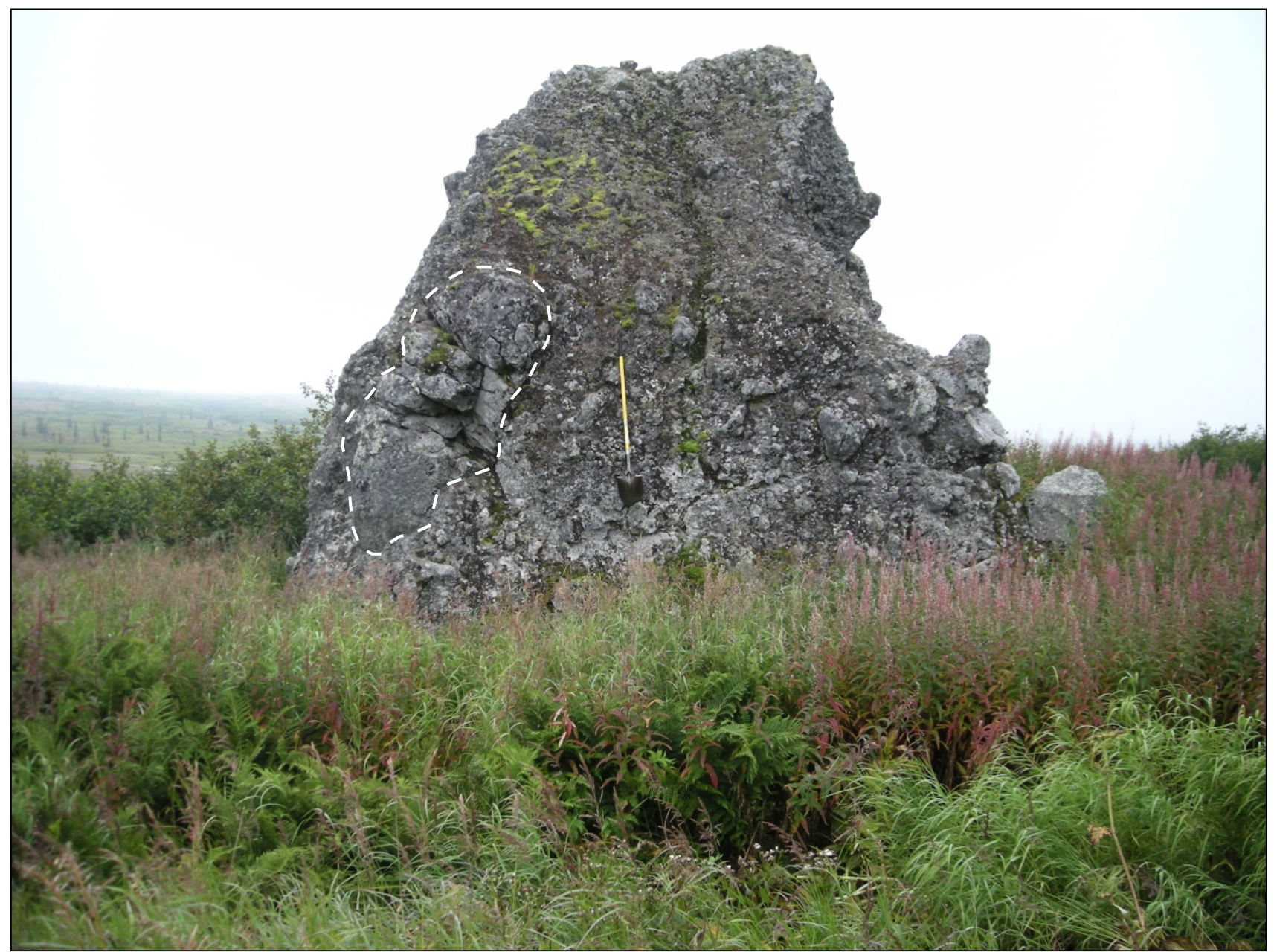

Figure 6 . Large volcaniclastic erratic on upper Chuitna drift northwest of Lone Ridge (N61 $14^{\prime} 28.1^{\prime \prime}$, W151 $30^{\prime} 28.0^{\prime \prime}$ ) (sheet 1). Large, broken andesite block outlined by dashed line to left of shovel measures up to $1.9 \mathrm{~m}$ across. Yellow shovel handle is $1 \mathrm{~m}$ long. Photograph taken 08/19/2009 by R.D. Reger.

flank of Mount Spurr or a block flow on the volcaniclastic plateau to the west during the penultimate (MIS 4) glaciation of the area ${ }^{6}$.

We also dug a test pit into the crest of the drumlin-like ridge near the large erratic (sheet 1). Our pit exposed $95 \mathrm{~cm}$ of frost-stirred, mottled, tephra-rich, sandy loess blanketing the Upper Chuitna till (fig. 7). In a collection of 144 pebbles recovered from the till there, volcanic + granitic + metasediment clasts make up 62.5 percent of the total (table 2), providing corroborative evidence that the sources of the till are the volcaniclastic plateau and the Tordrillo Mountains west of the test pit. Rounded to subrounded quartz + black chert pebbles in the collection are likely derived from the Hemlock Conglomerate and the Tyonek Formation beneath the Beluga Plateau to the west (D. LePain, February 14, 2011, oral commun.).
Tracing the highest volcanic and exotic granitic and metasedimentary erratics related to the Upper Chuitna moraine around the margins of the volcaniclastic plateau from $3,000 \mathrm{ft}(915 \mathrm{~m})$ down to $2,500 \mathrm{ft}(762 \mathrm{~m})$ elevation, well above the level of ice during the last major glaciation, demonstrates that most of the volcaniclastic plateau stood above and beyond glacial limits in the late Pleistocene and that ice scouring was limited to the plateau margins (fig. 8). The northeastern and eastern plateau escarpments were scoured by ice from the Capps Glacier corridor, and the southwestern flank was scoured by ice from the Chakachatna River valley (figs. 3 and 8, sheet 1).

Evidence for the penultimate (MIS 4) glaciation includes (1) consistent topographic positions of the highest erratics $\sim 1,485 \mathrm{ft}(\sim 450 \mathrm{~m})$ above the level of the last major glaciation and (2) the presence of generally unweathered erratics

\footnotetext{
${ }^{6}$ Karlstrom (1964) named the penultimate glaciation in the Cook Inlet region after the Knik till, which is exposed only during very low tides on the northern shore of Goose Bay in Knik Arm near Anchorage (fig. 1). An ${ }^{40} \mathrm{Ar} /{ }^{39} \mathrm{Ar}$ age of 378 kya for the Goose Bay tephra in the Goose Bay peat, which is higher in the Goose Bay section than the Knik till, demonstrates that the type Knik till is older than 378 kya (Reger and others, 1996). Therefore, the Knik glaciation at the type locality considerably predates the penultimate glaciation, which cosmogenic-exposure ages indicate culminated during MIS 4 time (Briner and others, 2005; Briner and Kaufman, 2008; Matmon and others, 2010). Consequently, we have avoided using the term "Knik glaciation" for the penultimate glaciation in the Cook Inlet region and prefer to use marine-isotope stage nomenclature.
} 
in thin drift and remnants of Upper Chuitna lateral moraines on the northern and eastern flanks of the volcaniclastic plateau (figs. 9 and 10). We found no evidence for an older glaciation there or in the interior of the plateau. In contrast, granitic erratics in subdued lateral moraines along the southwestern edge of the volcaniclastic plateau are moderately weathered with significant surface modifications, although associated volcanic erratics appear unweathered ${ }^{7}$ (fig. 11). The moderately weathered (rough-surfaced) granitic erratics there imply a pre-penultimate (MIS 6) glaciation, but the intermixed unweathered (smooth-surfaced) volcanic erratics and the lack of evidence for a MIS 6 glaciation elsewhere on the volcaniclastic plateau imply a MIS 4 glaciation. Evidence

Table 2. Compositions of pebbles $(n=144)$ collected from test pit in Upper Chuitna till northwest of Lone Ridge (N61 $\left.14^{\prime} 27.7^{\prime \prime}, \mathrm{W} 151^{\circ} 30^{\prime} 31.8^{\prime \prime}\right)$ (sheet 1).

\begin{tabular}{|l|c|c|}
\hline \multicolumn{1}{|c|}{ Lithology } & $\begin{array}{c}\text { Number of } \\
\text { pebbles } \mathbf{( n )}\end{array}$ & Percent \\
\hline Volcanics & 60 & 41.7 \\
\hline Quartz & 43 & 29.9 \\
\hline Metasediments & 17 & 11.8 \\
\hline Granitics & 13 & 9.0 \\
\hline Cherts & 11 & 7.6 \\
\hline Total & $\mathbf{1 4 4}$ & $\mathbf{1 0 0 . 0}$ \\
\hline
\end{tabular}

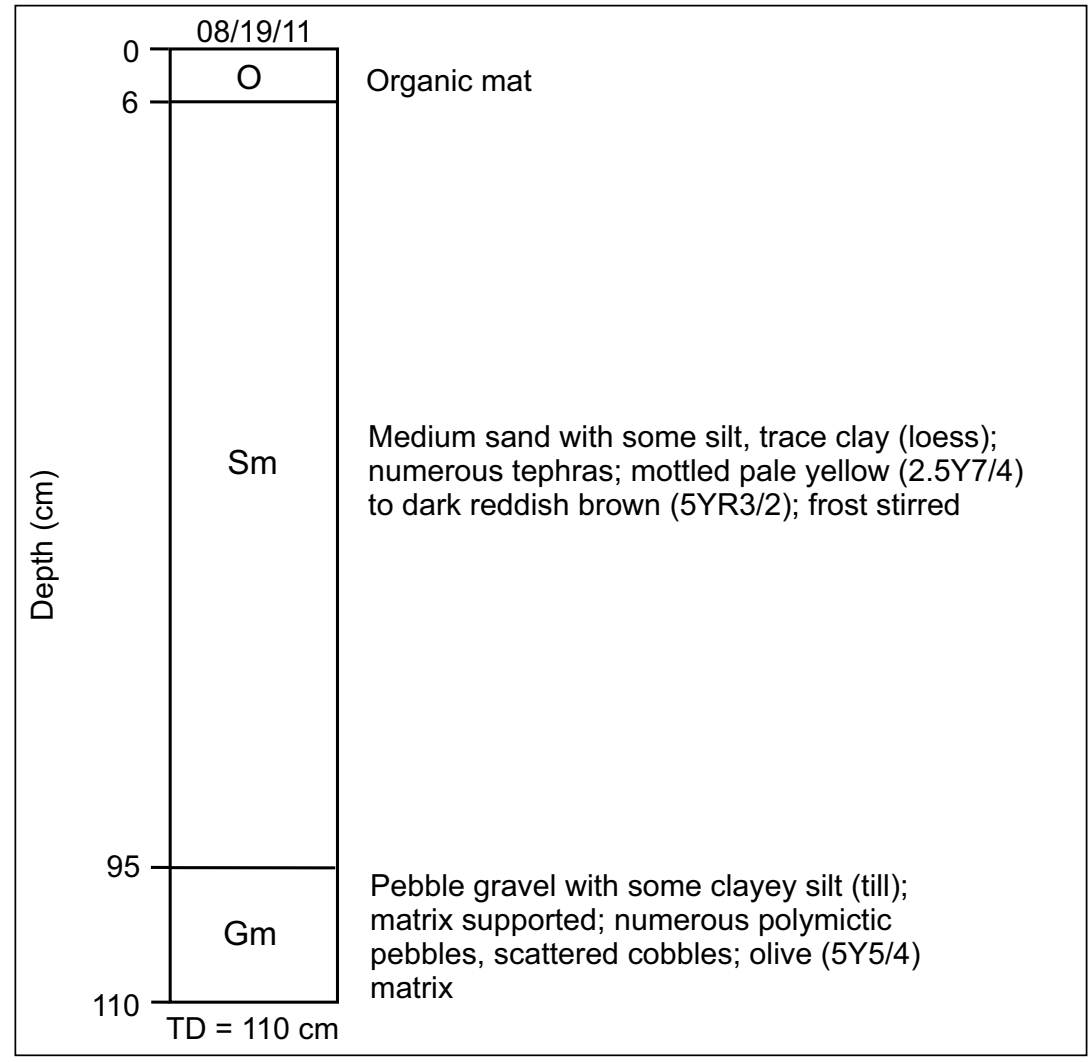

Figure 7. Stratigraphic section exposed in test hole in upper Chuitna drift north-

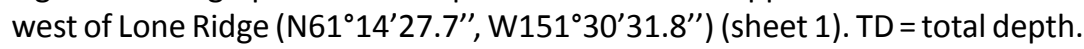

that possibly resolves this paradox was found at two sites at $\sim 4,000 \mathrm{ft}(\sim 1,219 \mathrm{~m})$ and $\sim 3,500 \mathrm{ft}(\sim 1,067 \mathrm{~m})$ elevation on the lower southern flank of the Mount Spurr edifice, where USGS geologists Andrew Calvert and Michelle Coombs dated palagonitized and complex columnar lava flows from Mount Spurr at 51 kya (A. Calvert, August 9, 2010, personal commun.), indicating that the lava flows advanced against glacial ice there late in the MIS 4 glaciation. A reconstructed MIS 4 paleo-ice gradient projected between those two localities is consistent with the level of weathered granitic erratics along the southwestern flank of the volcaniclastic plateau, perhaps supporting a MIS 4 age for those erratics also. Because the two sets of granitic erratics around the margins of the volcanic plateau were derived from different sources, we suggest that granitic erratics derived from the Chakachatna River valley weathered faster than granitic erratics derived from the Capps Glacier valley and both sets of erratics were likely deposited during the MIS 4 glaciation.

\section{LAST MAJOR GLACIATION}

The Naptowne glaciation was named by Karlstrom (1964) for deposits left by the last major glaciation along and near the Sterling Highway in the vicinity of the settlement of Naptowne (now called Sterling) in the eastern Kenai Peninsula lowland (Reger and others, 2007). Karlstrom initially proposed four stades in the Naptowne glaciation and identified type moraines for each. Later workers encountered difficulties reconciling Karlstrom's maps and glacial history with the field evidence, forcing reassessment of his model. Subsequent investigations in the type area (Reger and Pinney, 1996, 1997) accepted the concept and name of the Naptowne glaciation, which occurred during MIS 2, but suggested changing the name of the youngest stade to reflect better documentation of late-Naptowne events in the Anchorage area. The youngest stade is now known as the Elmendorf stade, and the type moraine is the Elmendorf terminal moraine north of Anchorage (Reger and others, 1995) (table 1).

Between $\sim 28$ and 32 cal. kya, glaciers in the Aleutian and Alaska ranges and in the Talkeetna, Chugach, and Kenai mountains began to thicken and spread into nearby lowlands (Mann and Peteet, 1994; Reger and others, 2007, fig. 6). The southern entrance of the Cook Inlet trough was apparently initially dammed when ice from the southern Kenai Mountains joined ice from Fourpeaked Mountain-Mount Douglas and Iliamna volcano accumulation centers, and a regional-scale meltwater lake was impounded in the Cook Inlet basin. The Cook Inlet ice sheet thickened and spread

\footnotetext{
${ }^{7}$ Moderately weathered granitic erratics generally "thunked" when struck with a hammer. In contrast, unweathered granitic and volcanic erratics generally rang when struck with a hammer.
} 


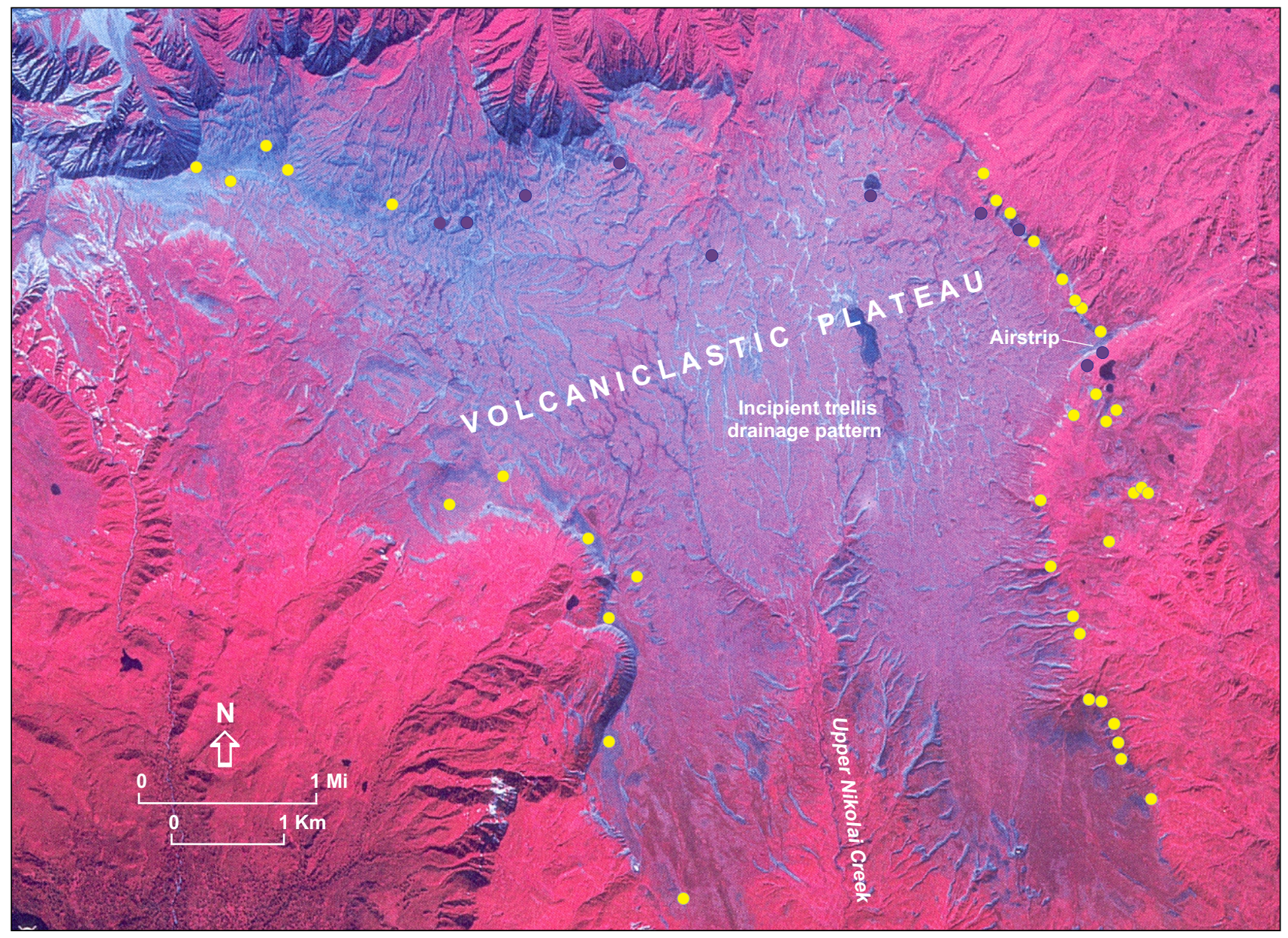

Figure 8. Vertical false-color infrared aerial photograph of volcaniclastic plateau, showing locations of erratics around plateau margins. Yellow dots denote localities where granitic erratics were found with erratics of volcanic and metasedimentary lithologies. Only volcanic clasts were identified on plateau interior at localities indicated by purple dots. Note parallel alignment of upper Nikolai Creek and incipient trellis drainage with prominent north trend on northwestern plateau (Alaska High Altitude Photograph ALK 60 CIR 6401 taken August 1978).

relatively rapidly across the basin floor to join locally with ice flowing less rapidly northwestward from the western Kenai Mountains at the maximum glacial extent $\sim 23$ kya during the Moosehorn stade, the earliest and longest stade recognized (Reger and others, 2007). A lengthy interval of thinning and recession, interrupted by brief stadial readvances, followed the climax of the last major glaciation, and the Naptowne glaciation ended $\sim 11$ cal. kya.

Moraines of the MIS 2 glaciation are fresh looking with high relief relative to older moraines (fig. 12), and relations between moraines and associated drainage features are obvious. Morainal margins are generally sharply defined, and minor topographic features such as small, sharp morainal ridges are well preserved. Kettles and kettle lakes are common and generally irregular, with fairly steep sides and rocky floors or thin fills. Erratics are generally unweathered, and loess covers are thin compared to older moraines.

\section{Moosehorn stade}

We place the maximum limit of the last major glaciation between $\sim 1,000$ and $\sim 1,500 \mathrm{ft}(\sim 305$ and $455 \mathrm{~m})$ elevation on the Beluga Plateau at the outer limits of the 1405 lakes and 810 lake lateral and terminal moraines of Schmoll and others (1984) and Schmoll and Yehle (1986), which physiographic evidence indicates are contemporary (fig. 3, table 1, sheet 1). Both lateral moraines lap onto the older Upper Chuitna drift. The 1405 lakes lateral moraine was built by the Chakachatna-McArthur Embayment lobe, and the 810 lake terminal moraine was deposited by ice that came from the Capps Glacier corridor to the west-northwest and wrapped around the northeastern end of Lone Ridge. Based on the freshness of these moraines and their positions outside the next younger moraines, which we confidently correlate with moraines of Killey age on the northwestern Kenai Peninsula Lowland, we assign the 1405 lakes and 810 lake moraines to the earliest stade of the Naptowne glaciation (table 1).

Radiocarbon dating of calcareous barnacle plates in sandy distal submarine fan deposits beneath a glaciomarine rainout diamicton in the bluff at Kenai indicates that ice shelves pushed into the Kenai area from the northwest $\sim 16.5{ }^{14} \mathrm{C}$ kya (Reger and others, 2007, fig. 60) (table 1). This implies that glaciers of late Moosehorn age were still advancing into ancestral Cook Inlet in the Tyonek area at that time. 


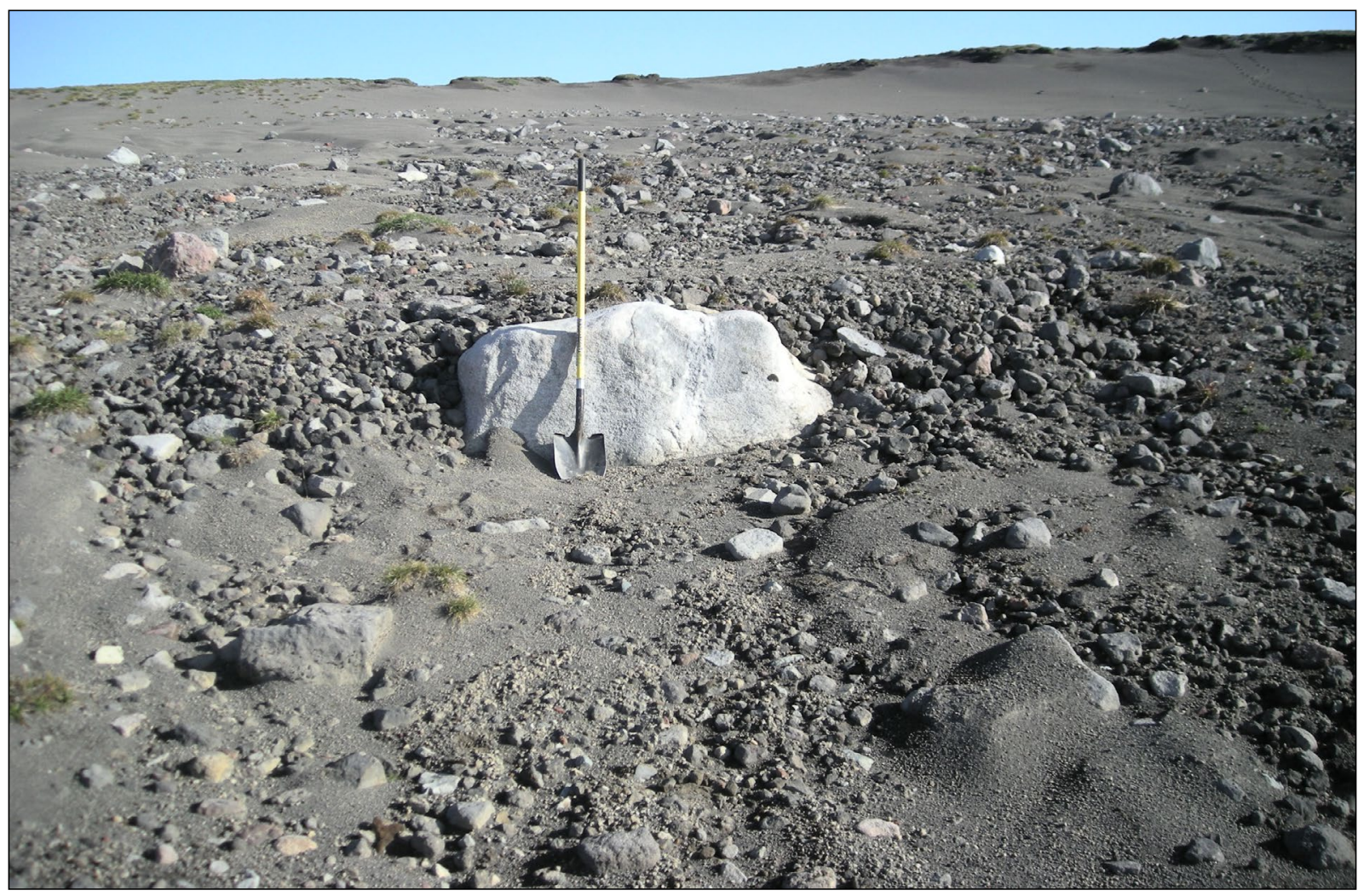

Figure 9. Large, unweathered granitic erratic in blanket of volcaniclastic sediments and erratics on northern flank of volcaniclastic plateau (N61 $\left.17^{\prime} 11.4^{\prime \prime}, \mathrm{W} 151^{\circ} 54^{\prime} 59.7^{\prime \prime}\right)$. Yellow shovel handle is $1 \mathrm{~m}$ long. Photograph taken $08 / 10 / 2009$ by R.D. Reger.

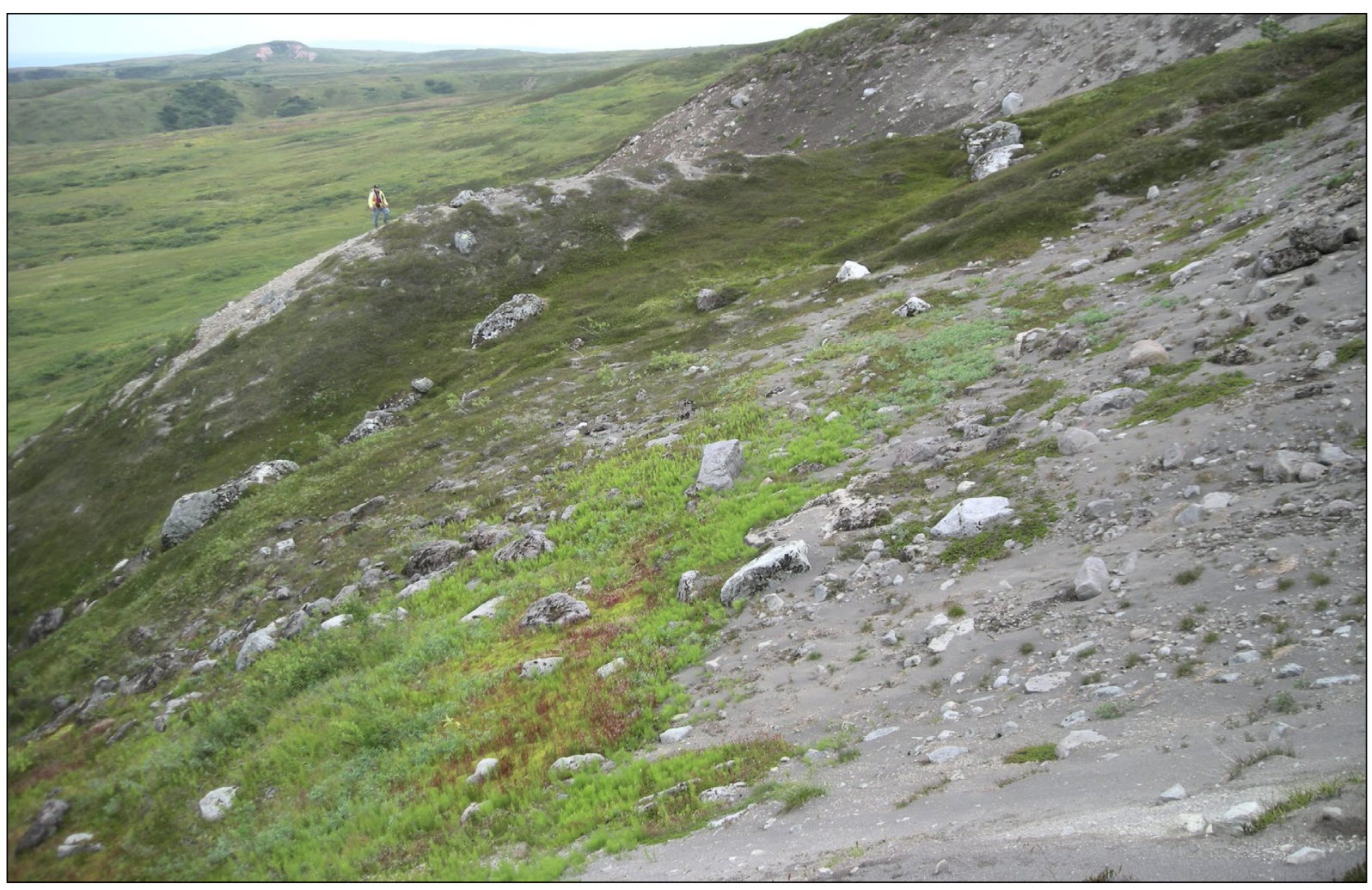

Figure 10. Scattered granitic and volcanic erratics on remnant of lateral moraine plastered against steep northeastern marginal scarp of volcaniclastic plateau (N61 ${ }^{\circ} 17^{\prime} 03.7^{\prime \prime}$, W151 $\left.41^{\circ} 46.2^{\prime \prime}\right)$. Geologist provides scale. Photograph taken 08/12/2009 by R.D. Reger. 




Figure 11. Mix of weathered (rough-surfaced) granitic and unweathered (smooth-surfaced) volcanic erratics on lateral

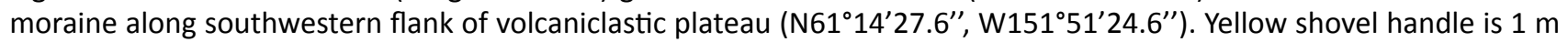
long. Photograph taken $08 / 17 / 2009$ by D.S.P. Stevens.

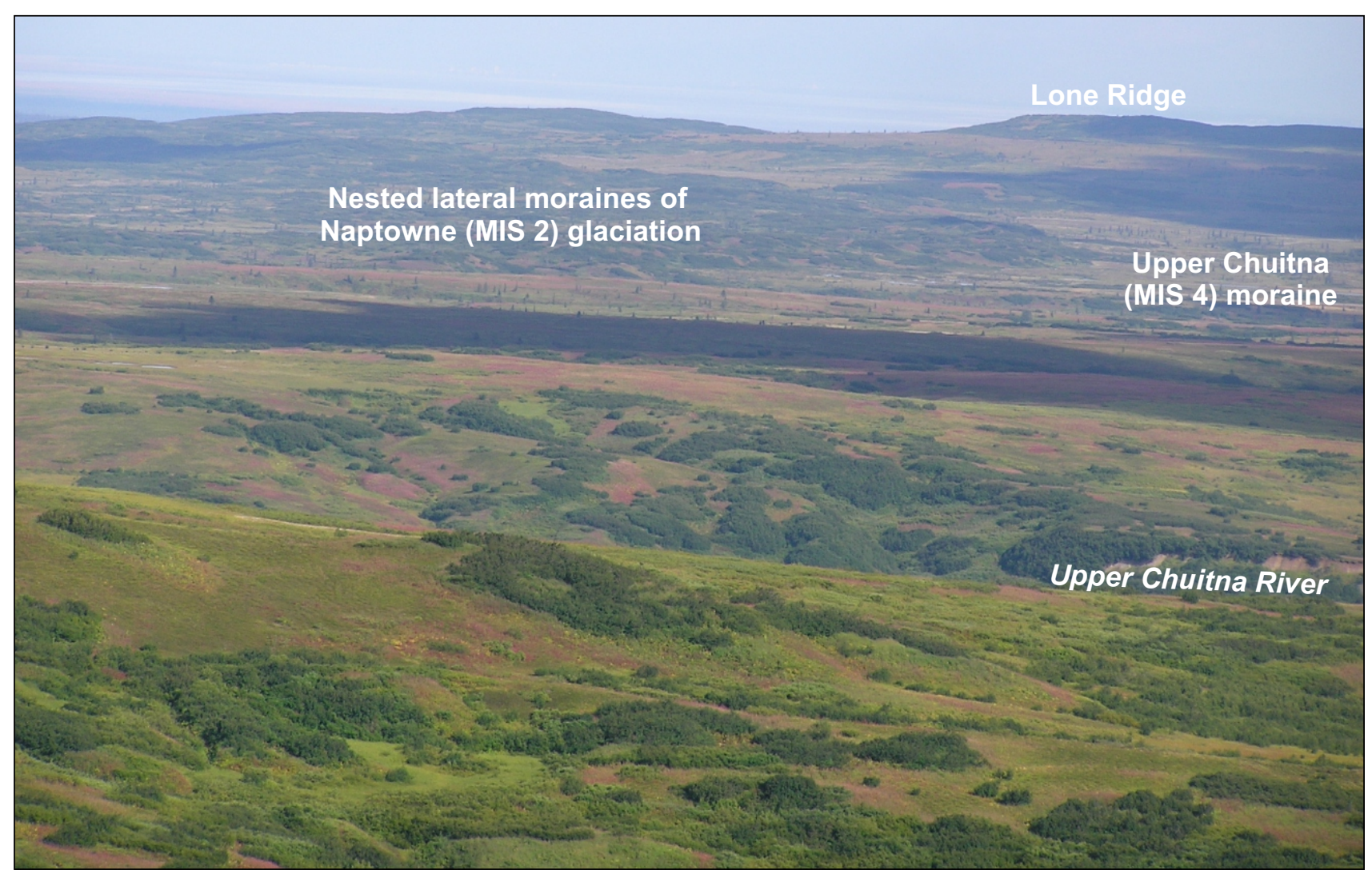

Figure 12. View east of Beluga Plateau from eastern flank of volcaniclastic plateau (N61 $\left.{ }^{\circ} 15^{\prime} 09.2^{\prime \prime}, W^{\prime} 151^{\circ} 47^{\prime} 07.8^{\prime \prime}\right)$, showing morphological contrast between high-relief lateral moraines of Naptowne (MIS 2) glaciation and subdued ground moraine of Upper Chuitna (MIS 4) glaciation. Photograph taken 08/19/2009 by D.S.P. Stevens. 


\section{Killey stade}

Our mapping of the 730 lake and Threemile Creek moraines of Schmoll and others (1984) and Schmoll and Yehle (1986) indicates that ice from the Capps Glacier corridor flowed eastward through the northeastern study area and joined with ice flowing southwestward from the southern Susitna Lowland after the climax of the Moosehorn stade (fig. 3 , sheet 1). Because the 730 lake terminal moraine is inset in the 810 lake moraine (fig. 3), we interpret the 730 lake moraine to be younger and tentatively assign the 730 lake and Threemile Creek moraines to the Killey stade (table 1). A distant minimum-limiting age for the 730 lake moraine is $10,140 \pm 150{ }^{14} \mathrm{C}$ yr BP (fig. 3 and table $3, \mathrm{RC}-5$ ), based on the dating of basal peat in swamp deposits sectioned in a coalexploration pit in the 730 lake terminal moraine (sheet 1).

We accept the contention by Schmoll and Yehle (1987) that the Nikolai moraine cuts across the Threemile Creek moraine in the vicinity of the lower Chuitna River, demonstrating that a slightly younger Killey advance occurred in the Chakachatna-McArthur Embayment. However, we found no prominent cross-cutting moraine along the junction of the two lobes, probably because of later incision by the Chuitna River or because the large, pitted Tyonek outwash fan was deposited there by the ancestral Chuitna River when it flowed beside the ice lobe from the Chakachatna-McArthur Embayment. Both the Nikolai moraine and fan gravels contain significant percentages of volcanic clasts. Pitting of the Tyonek fan is clear evidence that stagnant glacial ice existed in the Tyonek area north of the Nikolai moraine during the Killey stade (fig. 3, sheet 1).

Deposits that are exposed in the coastal bluff near the northern limit of the Nikolai moraine indicate the presence, during the Killey stade, of glacial ice in contact with a body of standing water, probably glaciolacustrine, to the northeast ${ }^{8}$. There, two diamictons overlie or are sandwiched between 0.9-1.5-m-thick layers of massive to medium-bedded, locally rippled sands that were deposited on the floor of the former water body. The upper diamicton is $4-5 \mathrm{~m}$ thick and contains scattered striated, angular to subangular cobble and boulder erratics of granitic and volcanic rock types as well as chunks of detrital coal. The lower diamicton is 5-6 $\mathrm{m}$ thick and is composed of matrix-supported sandy pebble gravel with numerous cobbles. Sharp planar contacts between the diamictons and the underlying undeformed sands argue against contact of glacial ice with the bottom of the former water body. However, the presence of scattered, small, angular to subangular dropstone boulders in the sand indicate that calving glacial ice was nearby. Both diamictons likely represent reworked till (flowtills) that flowed and slid off the nearby glacial ice into standing water. Dips in the sand layers indicate that the sandy floor of the former water body sloped gently eastward.
Ice from the Chakachatna-McArthur Embayment, called the Trading Bay lobe by Karlstrom (1964), extended across the Cook Inlet trough during the Killey stade and impinged on the northwestern Kenai Peninsula near Nikiski, where it partially floated in glacioestuarine waters of ancestral Cook Inlet and built a braidplain toward Kenai (Reger and others, 2007, fig. 9) (table 1). On the basis of key erratic compositions in both moraines, we can for the first time confidently correlate the Nikolai moraine with end moraines of Killey age east of Cook Inlet on the northwestern Kenai Peninsula ${ }^{9}$. In addition to numerous granitic and volcanic erratics, both moraines contain erratics of a distinctive pebble conglomerate with numerous striking spheroidal-to-oblate surface pits the size of pebbles (fig. 13). The pits were produced when acidic groundwaters dissolved or partially dissolved pebbles of light-gray to tannish-gray micritic limestone in the conglomerate. Relatively insoluble pebbles of mediumto dark-gray and black chert were unaffected by the acidic waters. Although conglomerates containing both gray and black chert and limestone pebbles have not been mapped in the Chakachatna River drainage, we suggest that the bedrock source of the chert clasts and unique micritic limestone pebbles could be related to thinly bedded Paleozoic chertargillite basinal rocks and shallow platform carbonates of the White Mountain sequence, which is exposed southeast of the Denali-Farewell fault in the western Lime Hills Quadrangle west of the Tyonek Quadrangle (Decker and others, 1994). This suggestion is reinforced by the presence of scattered erratics of thinly interbedded cherts and argillites in Nikiski moraines. We postulate that a shift in the Naptowne ice divide westward into the Lime Hills Quadrangle would

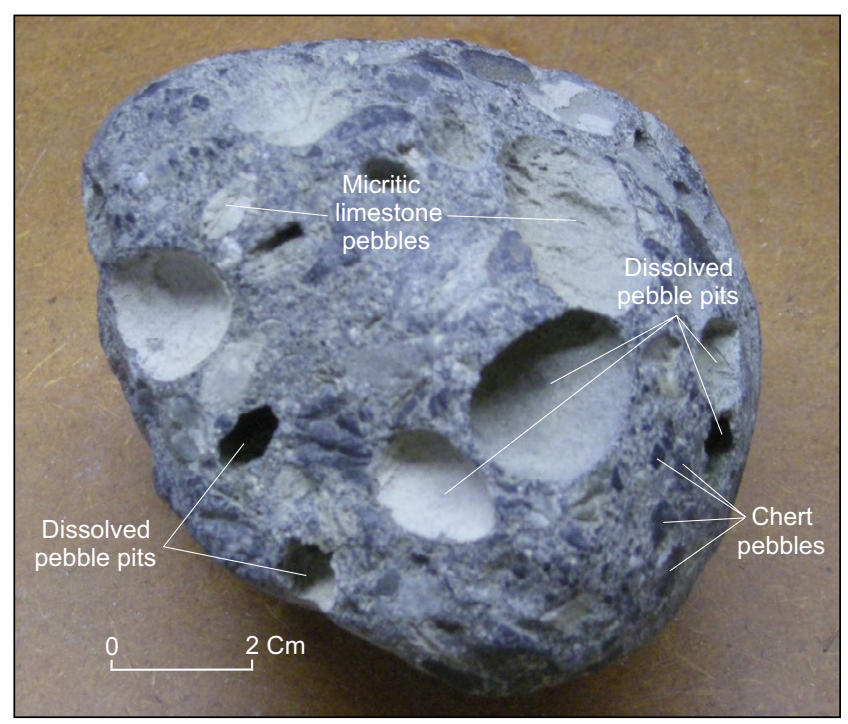

Figure 13. Pitted pebble conglomerate erratic of type found in both Nikolai and Nikiski moraines of Killey age. Photograph taken $01 / 31 / 2011$ by R.D. Reger.

\footnotetext{
${ }^{8}$ The extent of this former water body is unknown, but it has the same relation to the Nikolai moraine as a former ice-marginal lake has to Killey end moraines northeast of Nikiski on the northwestern Kenai Peninsula (Reger and others, 2007, fig. 9).

${ }^{9}$ Previously, Karlstrom (1964), Reger and Pinney (1996, 1997), and Reger and others (2007) recognized that the Nikiski moraines were deposited by ice from the west side of Cook Inlet because of the presence of numerous granitic, metamorphic, and volcanic erratics in the moraines there and projected the Trading Bay lobe to the Nikiski end moraines.
} 


\begin{tabular}{|c|c|c|c|c|c|c|c|c|c|c|c|c|c|}
\hline 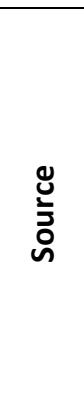 & 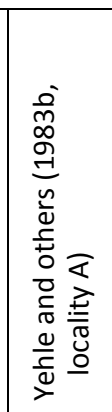 & 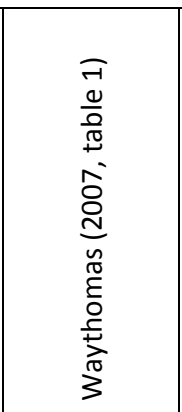 & 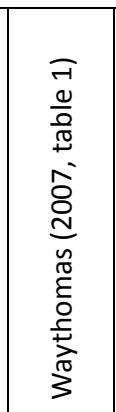 & 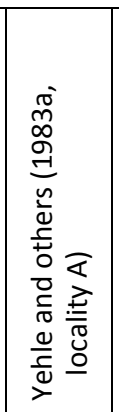 & 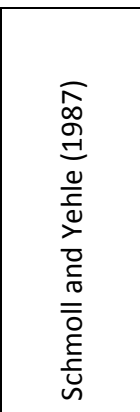 &  & 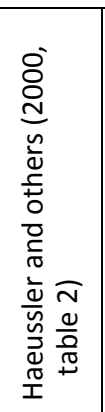 & 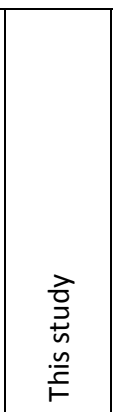 & 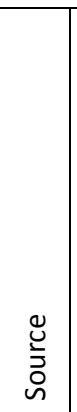 & 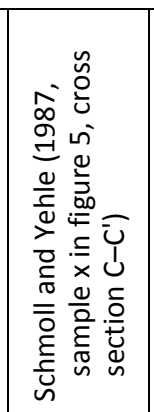 & 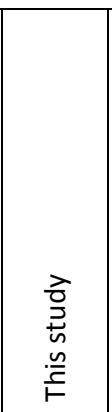 & 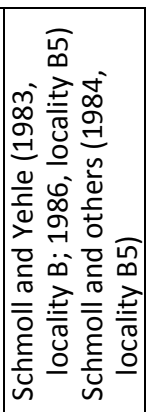 & \\
\hline 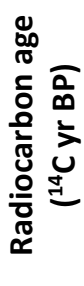 & $\begin{array}{l}0 \\
0 \\
+1 \\
0 \\
0 \\
m \\
m\end{array}$ & 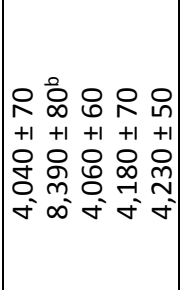 & 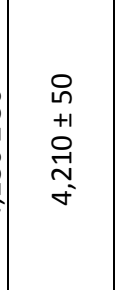 & 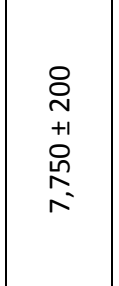 & 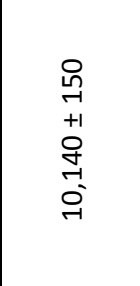 & 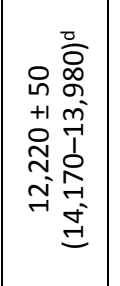 & 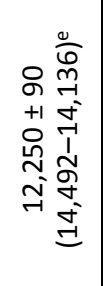 & 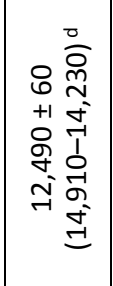 & 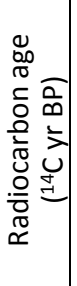 & $\begin{array}{l}\stackrel{0}{1} \\
+ \\
+1 \\
\stackrel{1}{1} \\
\infty \\
0 \\
\\
-1\end{array}$ & 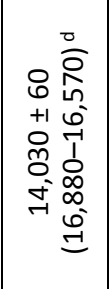 & 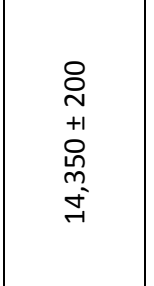 & \\
\hline 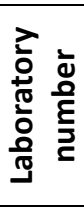 & 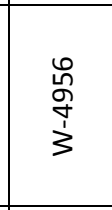 & 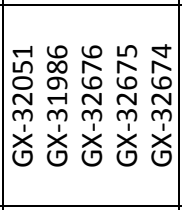 &  & $\begin{array}{l}0 \\
\text { ֻ̊ } \\
\text { + } \\
3\end{array}$ & $\begin{array}{l}\stackrel{0}{2} \\
\hat{n} \\
\stackrel{y}{1} \\
\underline{I}\end{array}$ & 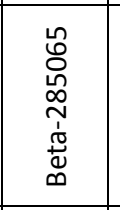 & 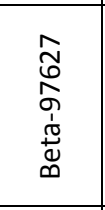 & 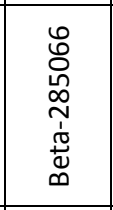 & 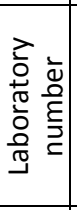 & 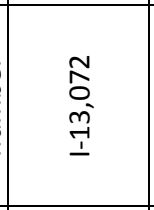 & 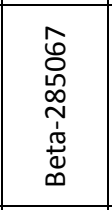 & \begin{tabular}{l} 
ָे \\
\multirow{Y}{*}{} \\
\multirow{3}{*}{}
\end{tabular} & \\
\hline 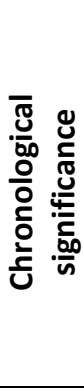 & 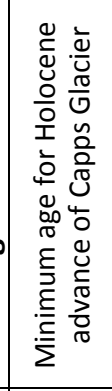 & 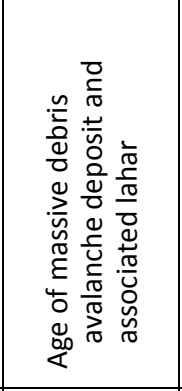 & 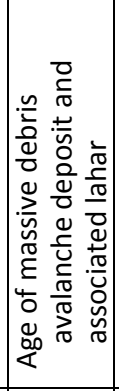 & 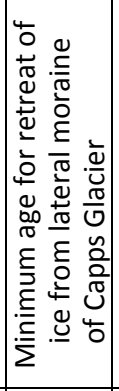 & 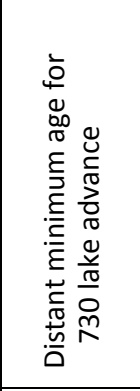 & 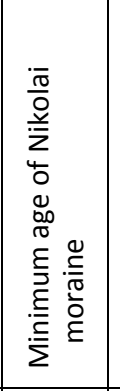 & 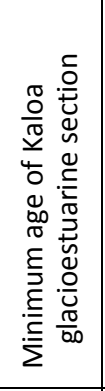 &  & 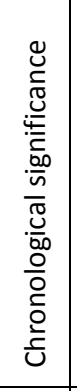 & 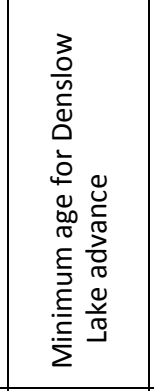 & 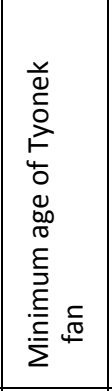 & 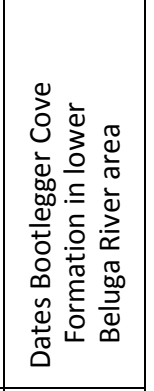 &  \\
\hline 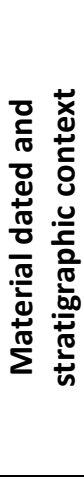 & 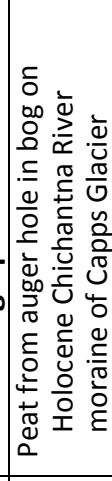 & 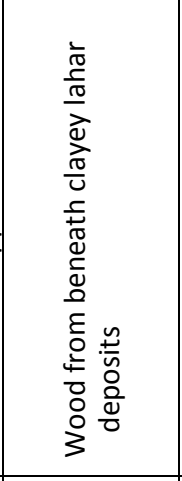 & 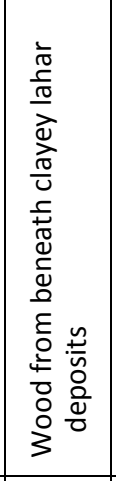 &  & 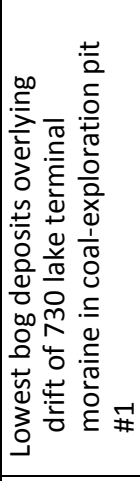 & 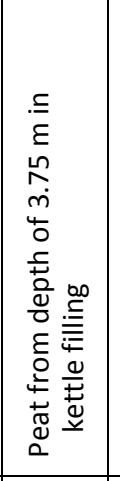 &  &  & 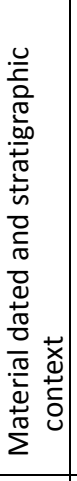 & 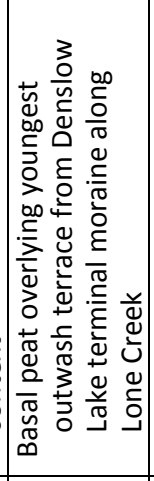 & 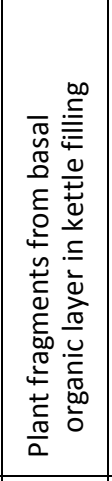 &  & 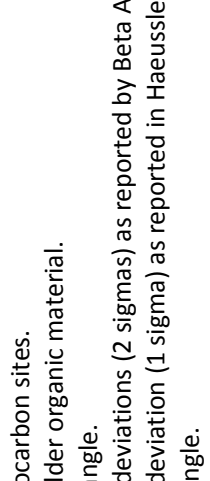 \\
\hline 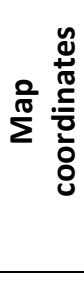 & 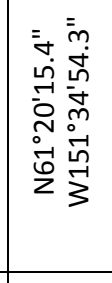 & 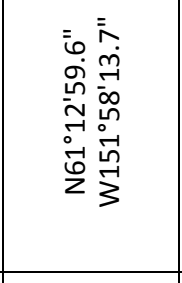 & 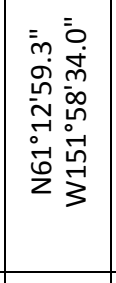 & 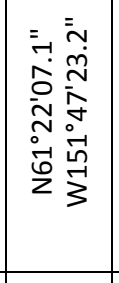 & 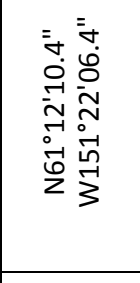 & 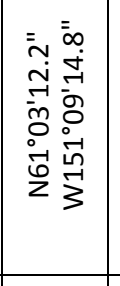 & 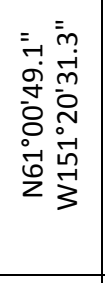 & 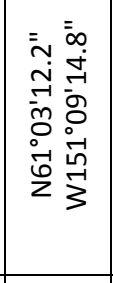 & 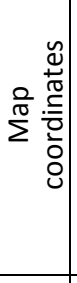 & 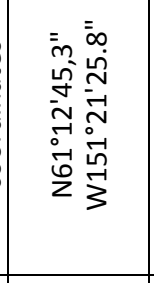 & 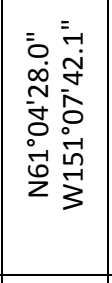 & 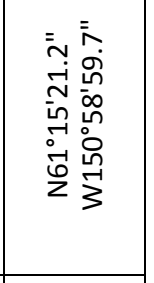 & 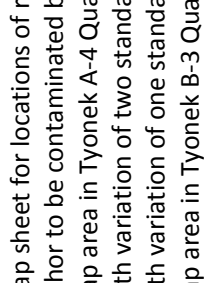 \\
\hline 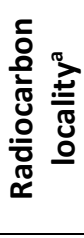 & 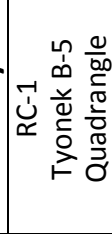 & 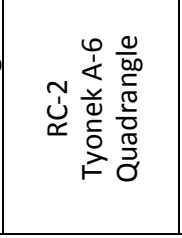 & 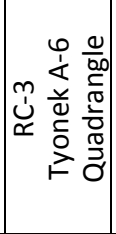 & 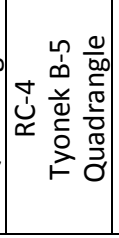 & 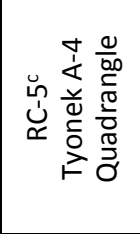 & 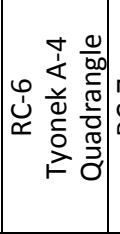 & 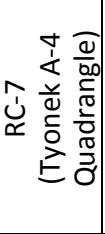 & 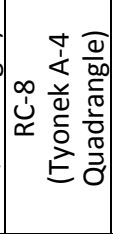 & 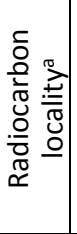 & 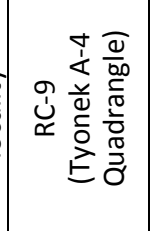 & 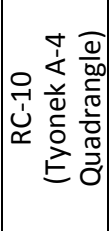 & 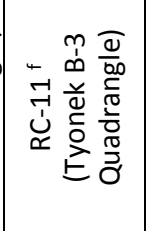 & 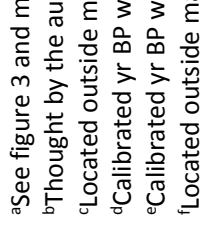 \\
\hline
\end{tabular}


provide glacier flow necessary to transport erratics from the Lime Hills Quadrangle eastward through the Chakachatna River valley into the Cook Inlet trough. We acknowledge the presence of conglomerates in the lower Cantwell Formation in the western Healy Quadrangle that contain both chert and micritic limestone pebbles (Csejtey and others, 1992) and that possible source rocks are described in the adjacent McKinley Quadrangle (Reed, 1961), but we conclude that those potential sources for the distinctive pebble conglomerate are well outside the source area of the glacier that carried conglomerate clasts through the Chakachatna River valley.

A glacial link between the Tyonek and Nikiski areas during the Killey stade is also demonstrated by scattered, rare chalcedony pebbles in the Nikolai moraine, in the Tyonek alluvial fan, in Nikiski end moraines, in subinlet pebble fan gravels in the Nikiski area, and in Tyonek and Nikiski beach gravels (Reger and others, 2007). Significant numbers of volcanic pebbles and cobbles associated with the chalcedony pebbles indicate that chalcedony was probably scoured from Quaternary volcanic rocks of the Mount Spurr edifice during the passage of ice down the Chakachatna River corridor ${ }^{10}$. The surfaces of many chalcedony pebbles retain the rough cortex that replicates the walls of gas cavities in lava flows. Although no chalcedony is mentioned in descriptions of post-Naptowne volcanic rocks in the Mount Spurr edifice, extensive alteration of the Holocene volcanic complex is demonstrated by the presence of hydrothermal clays and widespread, pervasive discoloration (Nye and Turner, 1990; Waythomas, 2001, 2007; Gillis and others, 2009). Probably most of the waters causing near-surface chemical and physical alteration came from the melting of snow and ice during and after Holocene eruptions. Waters containing sufficient silica to form chalcedony deposits in the volcanic pile chemically altered deeper zones that were subsequently eroded by thick glaciers flowing down the Chakachatna River valley during the MIS 2 glaciation. Likely conduits for those deepsourced acidic hydrothermal waters are the Capps Glacier and parallel faults, which apparently pass under the southern slope of the Mount Spurr volcanic complex (Waythomas, 2001, 2007; Gillis and others, 2009; Garchar and Wendlandt, 2012). Evidence indicates that chalcedony clasts entrained by glacial ice were initially deposited in the Nikolai moraine and then eroded by the ice-marginal Chuitna River to be carried downstream to the Tyonek alluvial fan. Ultimately, erosion by the Chuitna River and the waves of Cook Inlet freed the chalcedony pebbles from both the Nikolai moraine and the Tyonek outwash fan and scattered them in the beach gravels.

Radiocarbon evidence establishes minimum-limiting ages for the Nikolai moraine and the Tyonek fan in the study area. A sample of peat from the bottom of a 4.4-m-thick kettle filling, which includes interlayered thin tephras, diatomaceous earth, clean medium-to-coarse sand, organic silt, and thin peats exposed in the coastal bluff in the Nikolai moraine south of Tyonek, dates $12,490 \pm 60{ }^{14} \mathrm{C}$ yr BP (fig. 3 and table $3, \mathrm{RC}-8)^{11}$. A second peat sample collected in the same filling $65 \mathrm{~cm}$ above the basal sample dates $12,220 \pm 50{ }^{14} \mathrm{C}$ yr BP (fig. 3 and table 3, RC-6). Neither result is likely to be a close minimum-limiting age. An older, but still distant, minimum-limiting radiocarbon age of $14,030 \pm 60{ }^{14} \mathrm{C} \mathrm{yr}$ $\mathrm{BP}$ was provided by moss fragments in the basal organic-silt layer in a 4.7-m-thick kettle filling, which includes interlayered peat, organic silt, thin tephras, lake sediments, and loess, on the Tyonek fan that was exposed in the coastal bluff just north of Tyonek (fig. 3 and table 3, RC10).

On the east side of Cook Inlet on correlative braidplain deposits of Killey age north of Kenai, basal peat samples provided minimum-limiting ages of $12,900 \pm 300{ }^{14} \mathrm{C}$ yr BP (W416) and $13,500 \pm 400{ }^{14} \mathrm{C}$ yr BP (W-748), similar to the Tyonek area (Reger and others, 1996, table 2). The Killey age of that braidplain is confirmed by the presence of the Lethe tephra, which was deposited during late Killey time (Reger and others, 2007, fig. 53; Riehle and others, 2008).

\section{Skilak stade}

We interpret the Denslow Lake moraine, which was deposited on the northeastern Beluga Plateau by ice from the Capps Glacier corridor (fig. 3), to postdate the Threemile Creek moraine of Killey age and tentatively assign it to the Skilak stade (table 1). A distant minimum-limiting radiocarbon date for the Denslow Lake moraine is 13,820 \pm 170 ${ }^{14} \mathrm{C}$ yr BP (fig. 3 and table 3, RC-9) for basal peat and bog deposits overlying the youngest outwash alluvium related to the Denslow Lake moraine along Lone Creek (Schmoll and Yehle, 1987) (sheet 1).

Although not well constrained, the maximum extent of the Trading Bay lobe during the Skilak stade was likely located at or near the Middle Ground Shoal in Cook Inlet (Reger and others, 2007). No terminal moraine of Skilak age is recognized in the Chakachatna-McArthur Embayment in the map area, so we tentatively assign the Congahbuna Lake moraine, which clearly postdates the Killey-age Nikolai moraine, to the Skilak stade (fig. 3).

\section{Elmendorf stade}

Because it is located inside the Denslow Lake moraine, we tentatively assign the Carlson Lake moraine, which was deposited by ice flowing eastward in the Capps Glacier corridor, to the Elmendorf stade (fig. 3, table 1).

Late in the Naptowne glaciation, glacial ice from the Chakachatna-McArthur Embayment floated in ancestral Cook Inlet in the Granite Point-Beshta Bay area and rained onto the inlet floor a complex of glacioestuarine diamictons with varying contents of volcanic, granitic, and coal dropstones, informally named the Kaloa deposits by Schmoll and others (1984) and Schmoll and Yehle (1986) (sheet 1). During

\footnotetext{
${ }^{10}$ Beach gravels generally lacking chalcedony pebbles are dominated by flysch-related graywacke sandstone and slate/phyllite clasts and by granitic clasts. ${ }^{11}$ A collection of 22 pollen samples was taken at $10 \mathrm{~cm}$ intervals along a vertical profile through this kettle filling. USGS palynologist Tom Ager has completed preliminary scans of pollen slides from the lower $160 \mathrm{~cm}$ of the kettle filling and determined that a sufficient amount of pollen is preserved to develop a meaningful pollen profile. He has differentiated four pollen zones and determined that the oldest postglacial floral zone documented in this kettle fill is herbaceous tundra that was present at the site between $\sim 12.5$ and $\sim 12.2{ }^{14} \mathrm{C}$ kya (T. Ager, January 14 , 2011, written commun.)
} 
deposition of most of the Kaloa deposits, the inlet bottom remained isostatically depressed and ancestral Cook Inlet was too deep in the Granite Point area for grounding of glacial or shelf ice (Reger, 2009). Stratigraphic evidence in the upper coastal bluff at Granite Point indicates that the inlet floor had isostatically rebounded enough that inlet waters there were shallow late in the deposition of the section (Reger, 2009), and the lack of dropstones in the upper part of the section indicates that neither glacial ice nor ice shelves were present. A radiocarbon age of $12,250 \pm 90{ }^{14} \mathrm{C} \mathrm{yr} \mathrm{BP} \mathrm{(table} \mathrm{3,} \mathrm{RC7)} \mathrm{for}$ basal freshwater peat blanketing the Kaloa deposits provides a minimum-limiting age for those estuarine deposits.

A radiocarbon age of $14,350 \pm 200{ }^{14} \mathrm{C}$ yr BP (tables 1 and 3, RC-11) was obtained by Schmoll and Yehle (1983, 1986) for shells in silt and clay of the Bootlegger Cove Formation exposed in a low bluff along the lower Beluga River on the Bootlegger Cove Platform in the Tyonek B-3 Quadrangle $\sim 8 \mathrm{~km}$ east of the study area. Fine-grained sediments in bluffs along the lower Beluga River (fig. 2) and poor surface drainage on the Bootlegger Cove Platform north of Tyonek (fig. 14) indicate that the Bootlegger Cove Formation underlies the coastal plain there.

Based on similar compositions and radiocarbon ages, we tentatively correlate the glacioestuarine and estuarine Kaloa deposits in the Granite Point section with the fossiliferous Bootlegger Cove Formation along the lower Beluga River and consider both deposits to be equivalent to younger facies of the time-transgressive Bootlegger Cove Formation in the upper Cook Inlet region (Reger and others, 1995, 1996, 2007) (table 1).

\section{ALASKAN GLACIATION}

Arcuate morainal belts, informally named the 430 lake and Chichantna River moraines (fig. 3), and associated outwash alluvium were deposited during Holocene advances of Capps Glacier in the north-central study area. (fig. 3, sheet 1). Basal peats overlying lateral and end moraines of the Chichantna River moraine assemblage are dated 7,750 \pm 200 ${ }^{14} \mathrm{C}$ yr BP (table 3, RC-4) and 3,540 $\pm 60{ }^{14} \mathrm{C}$ yr B.P. (table 3, RC-1), respectively, by Yehle and others (1983a, b), providing minimum-limiting ages for those Neoglacial advances of Capps Glacier. Undated 353 lake moraine and Straight Creek moraine indicate that Neoglacial advances also occurred in those drainages in the southwestern map area (fig. 3, sheet 1). Fresh-looking Little Ice Age (LIA) end moraines, some still ice cored, between Neoglacial end moraines and modern glacial snouts record minor glacial expansions or stillstands during the past several centuries (fig. 3).

\section{SLOPE-FAILURE DEPOSITS}

Geologic studies have identified two classes of major subaerial slope failures in the map area: (1) extensive landslides in the Tertiary bedrock (Barnes, 1966; Schmoll and others, 1981; Yehle and others, 1983a, b) and (2) a massive volcanic-debris avalanche in the Chakachatna River valley

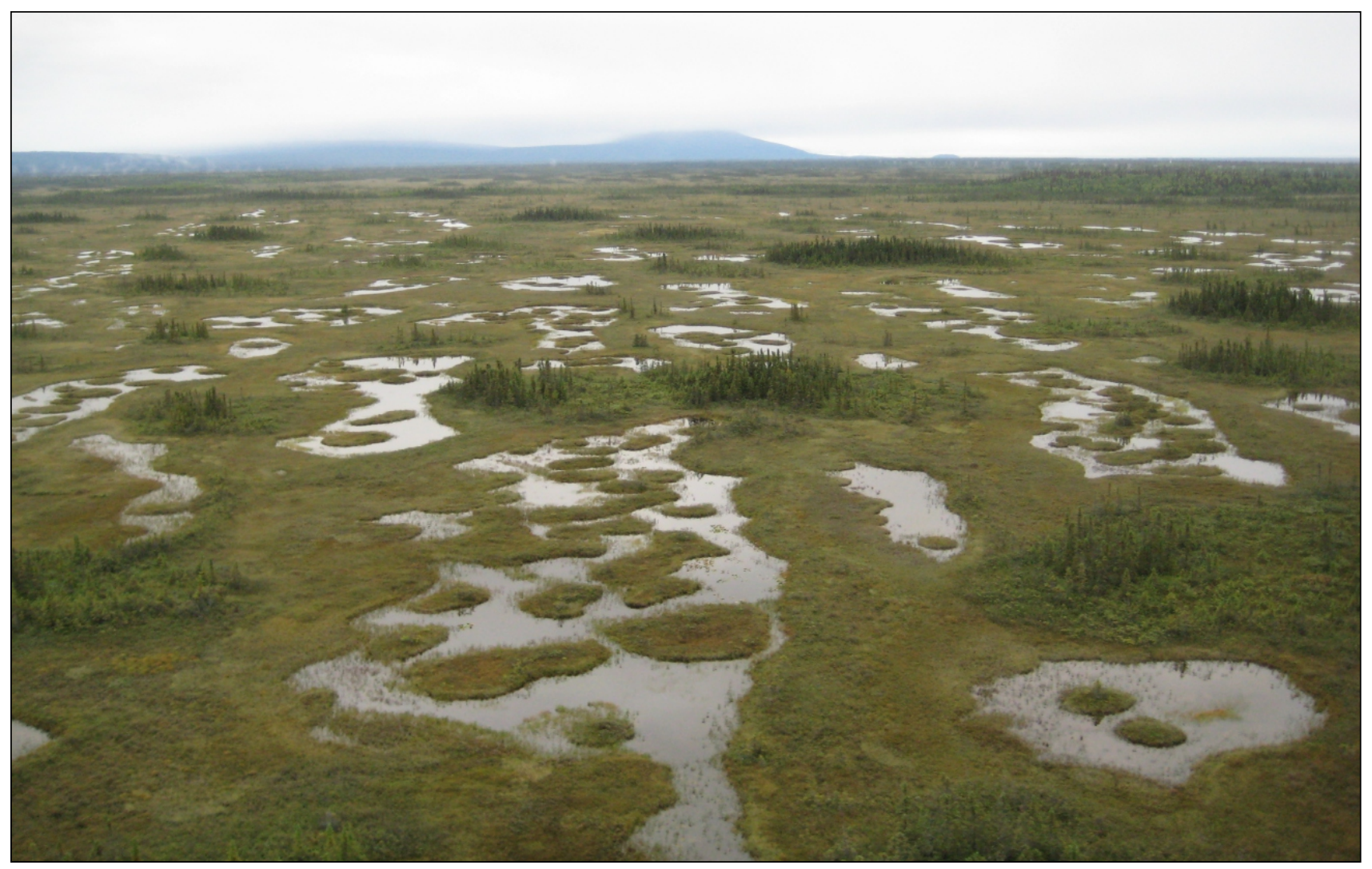

Figure 14. Aerial view northeast of poorly drained, peat-blanketed Bootlegger Cove Platform inland from northwestern coast of Cook Inlet, north of Tyonek. Photograph taken 08/15/2010 by R.D. Koehler. 
(Waythomas, 2007). Reinterpretation of the section at Granite Point attributes allochthonous blocks of disrupted coal and sandstone exposed in the succession of glacioestuarine diamictons there to subinlet slope failures during the late Naptowne glaciation (Reger, 2009).

\section{MAJOR LANDSLIDES IN TERTIARY BEDROCK}

The volcaniclastic plateau in the northwestern map area is gradually being dismantled by complex landslides, particularly along the southwestern margin but also along the northeastern and eastern margins (sheet 1). An incipient trellis drainage system, developed along generally north-striking linear ground fissures on the plateau, could be evidence of gravitational spreading to the east and west. The closelyspaced joints and short-displacement vertical faults on the plateau, which likely promote the headward growth of massive landslides, could also be the result of gradual drying of the volcaniclastic sequence. Directions of mass displacements away from the plateau edges are indicated by: (1) orientations of headwalls and lateral scarps; (2) truncations of lateral moraines; (3) orientations of rotated slide blocks; (4) transverse wrinkle ridges, scarps, and swales, some with sag ponds and small lakes; (5) longitudinal grooves and ridges; and (6) terminal bulges and ridges (figs. 15 and 16).

\section{SLIDES IN CHAKACHATNA RIVER VALLEY}

Southwest of the volcaniclastic plateau, landslides on the glacially steepened northeastern wall of the Chakachatna River valley have relatively steep surface gradients (sheet 1 ). One prominent failure has an average longitudinal gradient of $\sim 120 \mathrm{~m} / \mathrm{km}$. These complex slope failures form a chaotic terrain of rotated blocks and slide blocks that is deeply incised by small drainages (fig. 15). Headwall scarps stand up to $\sim 90$ $\mathrm{m}$ high, indicating that the slides are deep seated. The local bedrock is the West Foreland Formation of middle Eocene age and the Tyonek Formation of early Oligocene through middle Miocene age (fig. 17) (Magoon and others, 1976).

Southeast of the Lake Clark fault along the glacially steepened northeastern wall of the Chakachatna River valley, a large, deep-seated, complex rotational slope failure truncates the Congahbuna Lake moraine of Skilak age (fig. 3,

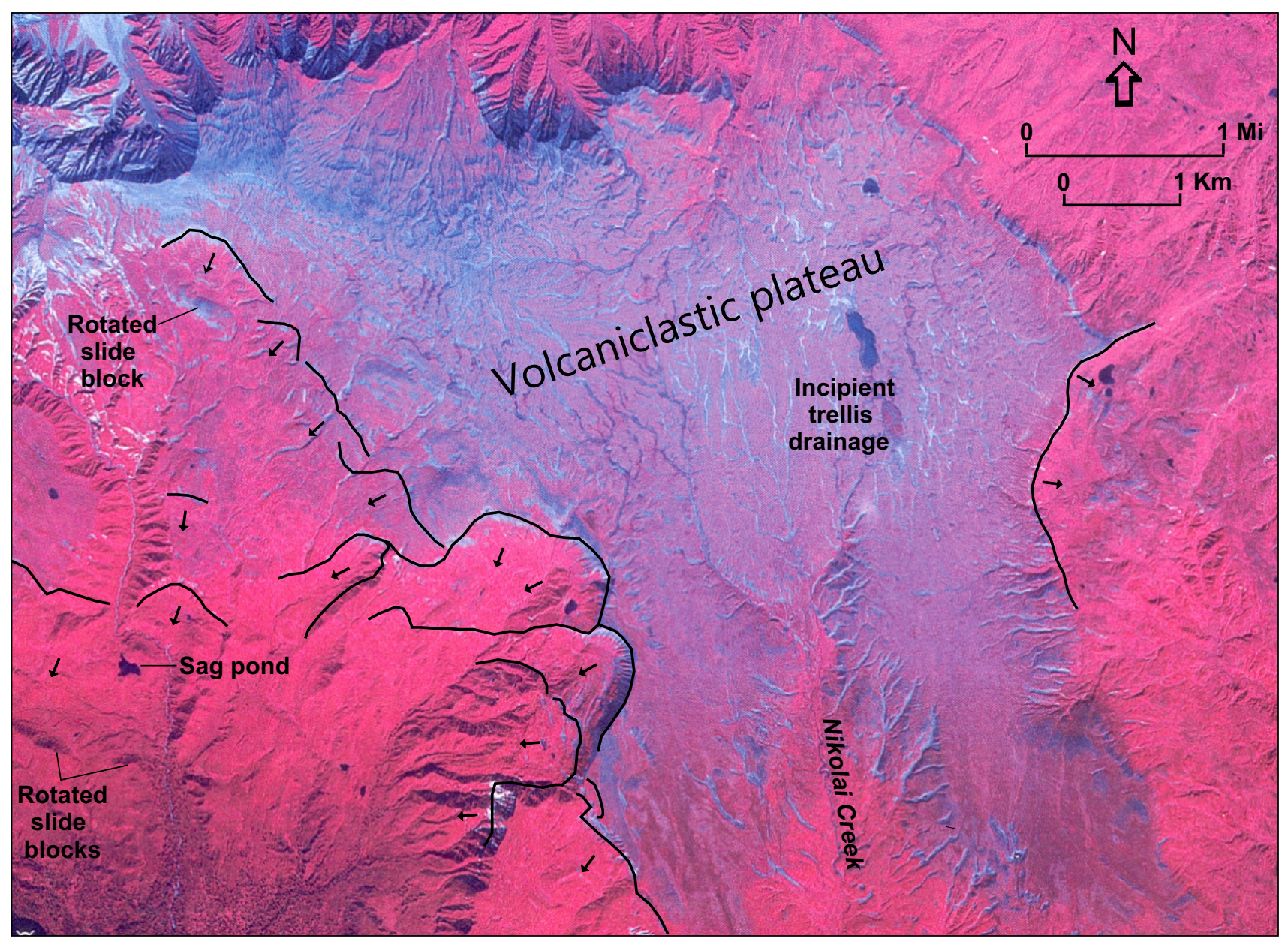

Figure 15. Vertical false-color infrared aerial photograph, showing features of complex mass displacements around volcaniclastic plateau in northwestern map area. Solid lines indicate landslide headwalls. Arrows indicate directions of mass movements. Incipient trellis drainage is developed along north-trending bedrock joints and vertical fractures (Alaska High Altitude Photograph ALK 60 CIR 6401 taken August 1978). 


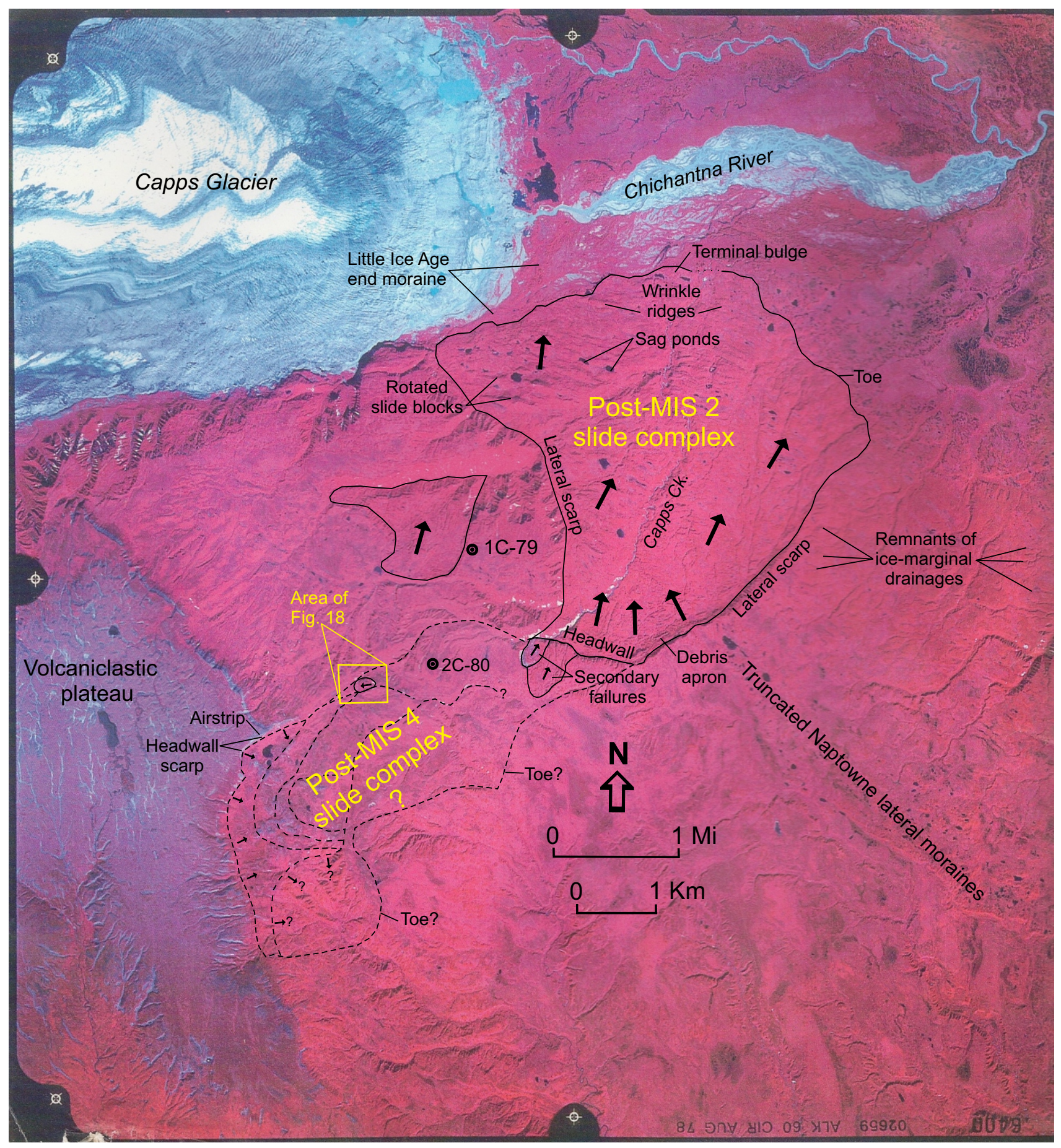

Figure 16. Vertical false-color infrared aerial photograph, showing two slide complexes on slope between Chichantna River and volcaniclastic plateau in north-central map area. Solid lines indicate limits of post-MIS 2 slide complex. Dashed lines indicate limits in post-MIS 4 slide complex(?). Arrows indicate directions of mass movements. Locally, surface runoff preferentially follows small, discontinuous ice-marginal channels of last major glaciation. Symbols $1 \mathrm{C}-79$ and $2 \mathrm{C}-80$ locate USGS bedrock boreholes (Odum and others, 1986) (Alaska High Altitude Photograph ALK 60 CIR 6400 taken August 1978). 
sheet 1). Headward erosion by a small tributary stream has partially dissected the body of the failure parallel to the headwall, indicating that more than one failure surface is present. This failure of the Tyonek Formation measures $7 \mathrm{~km}$ wide by $2 \mathrm{~km}$ long and has a steep average surface gradient of $\sim 130 \mathrm{~m} / \mathrm{km}$. The terminal zone of this failure is buried by the large alluvial fan of the Chakachatna and McArthur rivers. Boreholes CW 81-2 and CE 821 were drilled into the lower Tyonek Formation by the USGS $\sim 4.9 \mathrm{~km}$ and $9.7 \mathrm{~km}$ northeast of this large failure, respectively (Odum, 1986; Odum and others, 1986) (sheet 1). Those borings indicate that the dominant lithologies of the bedrock in this part of the Chuitna coal field are sandstones and siltstones (table 4) and the thickness of glacial drift at the drill sites is $1.8 \mathrm{~m}$ and 3.1 $\mathrm{m}$ (Odum and others, 1986, fig. 5C and D). Between zones of disturbance near faults in the Chuitna River valley, Barnes (1966) measured bedding-plane dips between horizontal and 10 degrees and described numerous coal beds varying in thickness from $\sim 1 \mathrm{~cm}$ to $\sim 15.5 \mathrm{~m}$.

The ultimate cause of the landsliding on the northeastern wall of the Chakachatna River valley is probably oversteepening of the valley wall by glacial erosion during the MIS 2 glaciation followed by debuttressing of the steep valley slope when the supporting glacier receded. Rather than failing catastrophically and producing rock avalanches in that area of fairly low relief, the Tertiary sedimentary rocks there failed as complexes of deep-seated slides, including rotational slumps.
Contributing factors likely include (1) thick, unwelded tuffs and tuffaceous sediments in the upper West Foreland Formation (Magoon and others, 1976) and (2) structurally weak layers of sandstone (particularly where weakly lithified), siltstone, and claystone that have fairly low unconfined compressive strengths in the Tyonek Formation (Odum and others, 1986). Losses of weakly lithified sandstones in the four USGS boreholes drilled in the Tyonek Formation ranged from 62.5 to 76.0 percent of the sandstones cored, indicating that these layers are particularly susceptible to failure. Among the clay minerals present, kaolinite and illite are the most abundant, typically comprising $40-60$ percent of the clay fraction, and montmorillonite exceeded 10 percent only in three samples from borehole CW 81-2 (Odum and others, 1986, table 5). Moisture contents were consistently less than saturation and less than plastic Atterberg limits, except for a few thin zones of perched water (Odum, 1986; Odum and others, 1986). Neither permafrost nor ground ice was encountered in any of the boreholes.

\section{CAPPS GLACIER CORRIDOR}

On the glaciated, fairly gentle slope east and northeast of the volcaniclastic plateau and southeast of Capps Glacier, adjoining landslide complexes of two different ages form a belt between the margin of the volcaniclastic plateau and the floodplain of the Chichantna River (sheet 1, fig. 16).

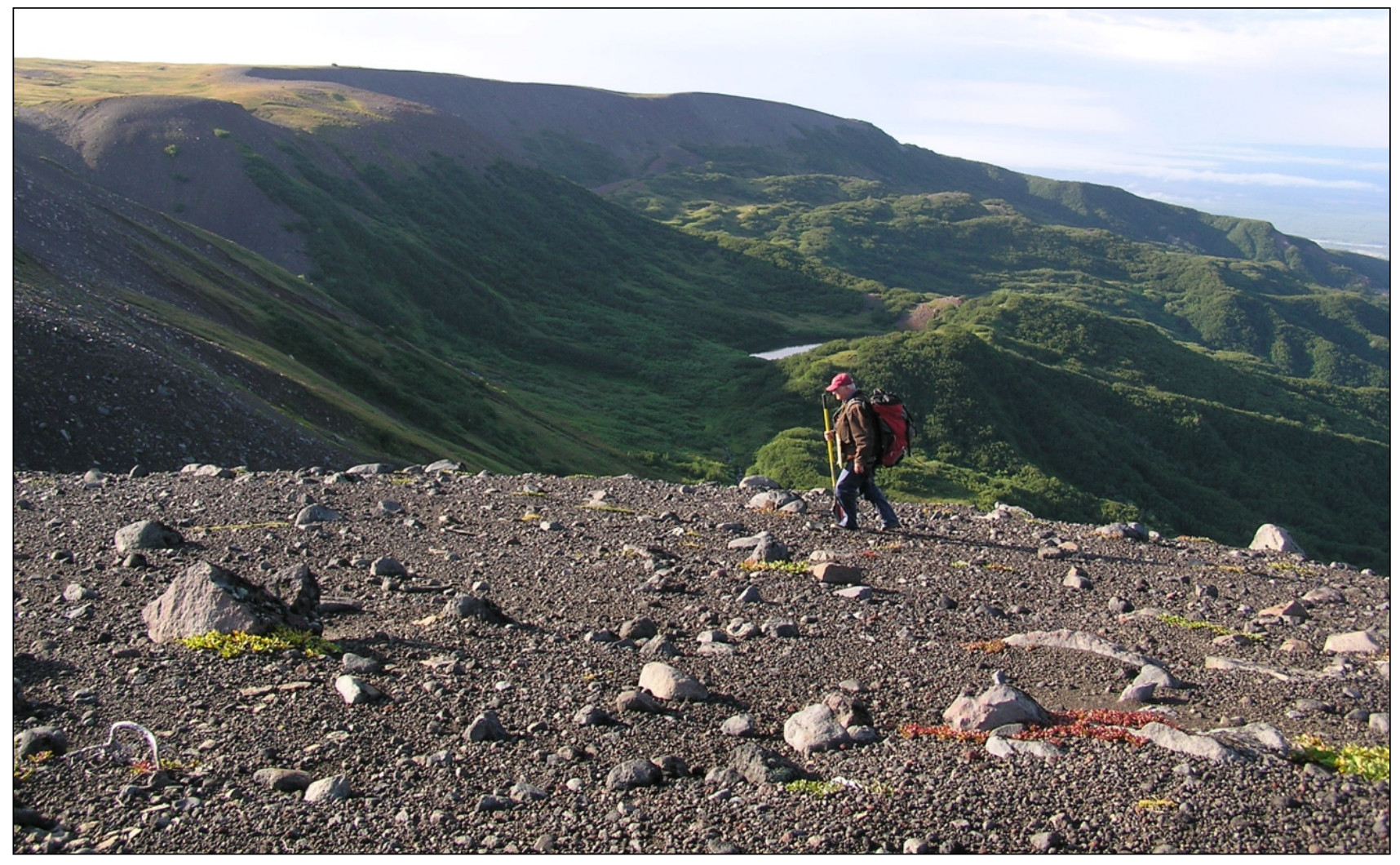

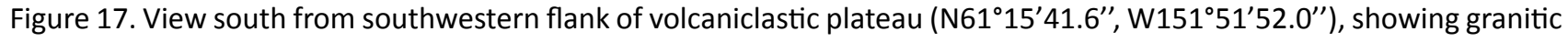
and volcanic erratics scattered in volcaniclastic sediments in foreground and active landslides in Tyonek Formation in middleground. Geologist provides scale. Photograph taken 08/17/2009 by D.S.P. Stevens. 


\section{Post-MIS 2 landslide complex}

The post-MIS 2 landslide complex, which is bisected by Capps Creek, has a surface area of $\sim 16.4 \mathrm{~km}^{2}$ and a relatively shallow average longitudinal gradient of $\sim 70 \mathrm{~m} / \mathrm{km}$ (sheet 1 , fig. 16). Obvious slide-related surface features include several sag ponds, numerous prominent wrinkle ridges and rotated slump blocks, and a sharp, multi-lobed terminal margin (toe) associated with discontinuous terminal bulges against the Little Ice Age end moraine of Capps Glacier and along the southern margin of the Chichantna River floodplain. The short but fairly straight west-northwest-trending headwall of this feature, which is supported by the exceptionally thick Capps coal bed (Barnes, 1966, pl. 5, loc. 78), is near vertical and $\sim 50 \mathrm{~m}$ high. Secondary failures at the top of the headwall, with surface areas of 0.2 and $0.1 \mathrm{~km}^{2}$, have expanded headward in a southwest direction into the older, adjoining slide complex. Lateral scarps are steep to vertical, are linear or have linear segments, and stand 30-150 m high (Barnes, 1966, p. C23). A debris apron is present along the base of the headwall and the southeastern lateral scarp. The segmented western lateral scarp is dissected by short gullies that terminate at the margin of the slide. The southeastern lateral scarp cuts off the prominent Naptowne (MIS 2) lateral moraine (fig. 16), establishing the age of the landslide complex as younger than the last major glaciation. Remnants of former ice-marginal drainage channels on the drift-covered, gentle slope southeast of the slide complex also terminate at the slide margin (fig. 16).

The body of the slide consists of many large blocks of coal-bearing siltstones of the Tyonek Formation with divergent attitudes, attesting to displacements by mass movement (Barnes, 1966). As indicated by the logs of boreholes 1C-79 and $2 \mathrm{C}-80$ (fig. 16), the near-surface Tyonek Formation in that part of the Capps coal field is dominantly sandstones, siltstones, and claystones with interbedded coal beds, including the exceptionally thick Capps and Waterfall coal beds, which are structurally stronger than the noncalcareous clastic sedimentary rocks above and below them (Odum and others, 1986, figs. 5A and B).

The log of USGS borehole 1C-79 also demonstrates that the thickness of glacial deposits at the drill site near the headwall of this slide complex is $9.5 \mathrm{~m}$ (Odum and others, 1986, fig. 5A). The presence of numerous gullies in the upland drift $\sim 1.2 \mathrm{~km}$ to the east along the western lateral scarp is evidence that the drift sheet is thicker there than along the headwall and the southeastern lateral scarp, where no gullies exist and shallow bedrock supports vertical, linear scarps.

Until sections through the landslides associated with the Capps coal field are exposed and examined in detail, our concepts of the evolution of these features are, to a certain extent, speculative. However, available surface and nearsurface evidence allows some deductions about the processes involved.

Headward and lateral expansions of the post-Naptowne slide complex involve processes active at the headwall and lateral scarps, which are supported by relatively high-strength coal beds. Recession of these scarps requires that bedrock be removed from the scarp faces, and examination of those scarps indicates that large slabs are initially detached and fall onto the debris apron along the base of the scarps (fig. 16). The widths of the slabs and their extents are likely controlled by the spacing and extents of bedrock joints. Once incorporated into the debris apron, weathering processes such as frost splitting and oxidation of coals operate to reduce the integrity and size of the slabs, and mass-movement processes shift the slabs and their weathering products downslope, away from the scarp faces, incorporating them into the body of the slide.

Numerous fresh-looking wrinkle ridges, rotated bedrock blocks oriented perpendicular to displacement directions, and terminal bulges in the body of the post-Naptowne slide complex imply that mass movements involved a complicated interplay of sliding bedrock blocks and deforming glacial drift. Laboratory tests indicate that the siltstones and claystones in the Tyonek Formation have the consistency

Table 4. Total stratigraphic thicknesses and lithologic contents in four boreholes in Tyonek Formation, Capps and Chuitna coal fields (modified from Odum and others, 1986) (sheet 1).

A. Capps coal field

\begin{tabular}{|c|c|c|c|c|c|}
\hline \multirow{2}{*}{$\begin{array}{c}\text { USGS } \\
\text { borehole }\end{array}$} & \multicolumn{5}{|c|}{ Lithologic content (total core thickness in meters and percent) } \\
\cline { 2 - 6 } & Sandstone & Siltstone & $\begin{array}{c}\text { Claystone and } \\
\text { carbonaceous } \\
\text { claystone }\end{array}$ & Coal & Total \\
\hline 1 C-79 & $55.2(74.3 \%)$ & $1.6(2.2 \%)$ & $9.9(13.3 \%)$ & $7.6(10.2 \%)$ & $74.3(100.0 \%)$ \\
\hline 2C-80 & $11.8(35.5 \%)$ & $14.0(42.1 \%)$ & $3.1(9.4 \%)$ & $4.3(13.0 \%)$ & $33.2(100.0 \%)$ \\
\hline
\end{tabular}

B. Chuitna coal field

\begin{tabular}{|c|c|c|c|c|c|}
\hline \multirow{2}{*}{$\begin{array}{c}\text { USGS } \\
\text { borehole }\end{array}$} & \multicolumn{5}{|c|}{ Lithologic content (total core thickness in meters and percent) } \\
\cline { 2 - 6 } & Sandstone & Siltstone & $\begin{array}{c}\text { Claystone and } \\
\text { carbonaceous } \\
\text { claystone }\end{array}$ & Coal & Total \\
\hline CW 81-2 & $11.8(35.5 \%)$ & $14.0(42.2 \%)$ & $3.1(9.3 \%)$ & $4.3(13.0 \%)$ & $33.2(100.0 \%)$ \\
\hline CE 82-1 & $16.1(38.6 \%)$ & $10.7(25.7 \%)$ & $4.1(9.8 \%)$ & $10.8(25.9 \%)$ & $41.7(100.0 \%)$ \\
\hline
\end{tabular}


of firm soil to hard rock (Odum and others, 1986, fig. 11), which implies that softer bedrock units in the section would deform preferentially when stressed and that harder units would maintain their integrity and slide or rotate during mass movement. Sliding of a complex blanket of bedrock blocks and unconsolidated glacial drift implies (1) that the deforming material is saturated or has considerable water content and (2) that the shear strength of the deforming sediment is reduced enough to allow sliding, perhaps during dynamic loading caused by seismic shaking. Several sag ponds provide evidence that the water table is shallow in the post-MIS 2 slide complex (fig. 16). A shallow water table is favored by a shallow, planar bedrock surface that would inhibit ground-water infiltration. Mapping by Barnes (1966, pl. 5) and Wolfe and others (1966, pl. 2) indicates that the Tyonek Formation in the vicinity of the post-MIS 2 slide complex dips shallowly northward toward Capps Glacier. The shallowly sloping boundary between the base of the landslide and the bedrock surface likely has served as the failure plane for this blanket slide.

The presence of numerous small lobes along the arcuate toe of the MIS 2 complex and discontinuous terminal bulges indicates that the slide advances by rolling over the surface in front of it. The small lobes imply that the slide front advances amoeba-like as sediments in different sectors become saturated, porewater pressures increase, shear strengths decrease, and deformation occurs.

\section{Post-MIS 4 landslide complex(?)}

We tentatively map a relatively old landslide complex, labeled "post-MIS 4 slide complex?" in figure 16, that extends from the eastern scarp of the volcaniclastic plateau northeastward to the head of the younger, post-MIS 2 slide complex (sheet 1, fig. 16). Upper Capps Creek flows along the northern edge of the complex. Topographically, the slide complex has the general appearance of a thin blanket of MIS 4 glacial drift covering a jumble of circular-to-arcuate bedrock blocks that possibly slid or shifted short distances, probably before but also locally after the MIS 4 glaciation. Definitive evidence that mass movements have occurred in the complex is the arcuate headwall south of the airstrip on the volcaniclastic plateau. There the first slide ridge below the scarp at the margin of the volcaniclastic plateau south of the airstrip lacks MIS 4 granitic erratics, which are scattered on ridges farther away from the scarp (compare figs. 8 and 16). Clearly, the first ridge below the scarp must have dropped into place after the glaciation that deposited the erratics farther away from the scarp, or erratics would have been left on that ridge when the plateau margin was glaciated. Additional definitive evidence is present near the airstrip, where the near-vertical, northeast-trending headwall of the post-MIS 4 slide complex is oriented perpendicular to the direction of MIS 4 ice flow around the northeastern flank of the volcaniclastic plateau (fig. 16). Any scarps that formerly existed there were almost certainly greatly modified or eliminated by glacial erosion.

The positions of bedrock blocks in the complex are vaguely defined by aligned, discontinuous arcuate and linear gullies and tributary stream valleys (fig. 16). Measurements by Barnes (1966, pl. 5) in surface exposures indicate that bedding planes consistently dip very shallowly, and in the northwestern part of the complex dominantly dip shallowly northeastward. His sections in the southern part of the slide complex demonstrate that near-surface bedrock there consists of thin coal beds interlayered with claystones and siltstones. The log of USGS borehole 2C-80 (fig. 16) also shows that the thickness of glacial drift at the drill site within the limits of the slide complex is $1.8 \mathrm{~m}$ (Odum and others, 1986, fig. 5B). Exposures of burned coal beds in the Tyonek Formation in the headwall of a recent landslide $0.8 \mathrm{~km}$ west-southwest of the borehole location and in nearby surface exposures (fig. 18) also demonstrate that bedrock is fairly shallow in that area. Typically those zones are identified by the presence of yellow to brick-red or purple clinkers, and the former coal bed is converted by combustion to a soft yellow ash near the base of the burned zone (Barnes, 1966, p. C25). The small hill with the recent landslide in the middleground of figure 18 was thought by Barnes (1966, p. C25) to have formed by differential erosion of a resistant baked shale and clinker complex formed by the burning of the Capps or closely underlying coals.

Recession of the marginal scarp around the northeastern and eastern flanks of the volcaniclastic plateau is likely the result of oversteepening during scouring of the plateau margins by the MIS 4 glaciation. Closely spaced, parallel, vertical and near-vertical joints and small-offset fractures facilitate separation of blocks of volcaniclastic deposits from marginal scarps. On steep slopes below the edge of the plateau, mass-movement processes such as solifluction, frost creep, and debris flows transport erratics and volcaniclastic blocks downslope.

Factors causing development of the vaguely defined older slide complex are difficult to identify because (1) the surface morphology of the complex has apparently been significantly modified by glaciation, (2) an obvious free face no longer exists toward which the slides could move, and (3) the lower limits of the slide complex are not well defined (fig. 16). We speculate that drift of the MIS 4 glaciation probably covers the former slide terminus and fills the former lowland at the head of the Chuitna River toward which the complex moved prior to the penultimate glaciation.

The presence of a burned coal bed exposed in the headwall of a recent landslide in the Tyonek Formation (figs. 16 and 18) and the general concentric pattern of block limits in the slide complex could hint at a possible cause of the massive failure. The log of borehole 2C-80 (Odum and others, 1986, fig. 5B) demonstrates that the top of the 9.2-m-thick Capps coal bed is $19.4 \mathrm{~m}$ deep in the northwestern slide complex, and the Capps coal bed is separated from an underlying 3.1-m-thick coal bed by $0.8 \mathrm{~m}$ of carbonaceous claystone. If both of those thick coal beds burned in the subsurface as suggested by Barnes (1966, p. C25) (fig. 16), up to 12.3 $\mathrm{m}$ of surface subsidence could occur above the zone of combustion, logically providing room for nearby unburned bedrock blocks to slide into the former void. The concentric arrangement of the slide blocks could indicate that bedrock blocks shifted only short distances toward the former void. 


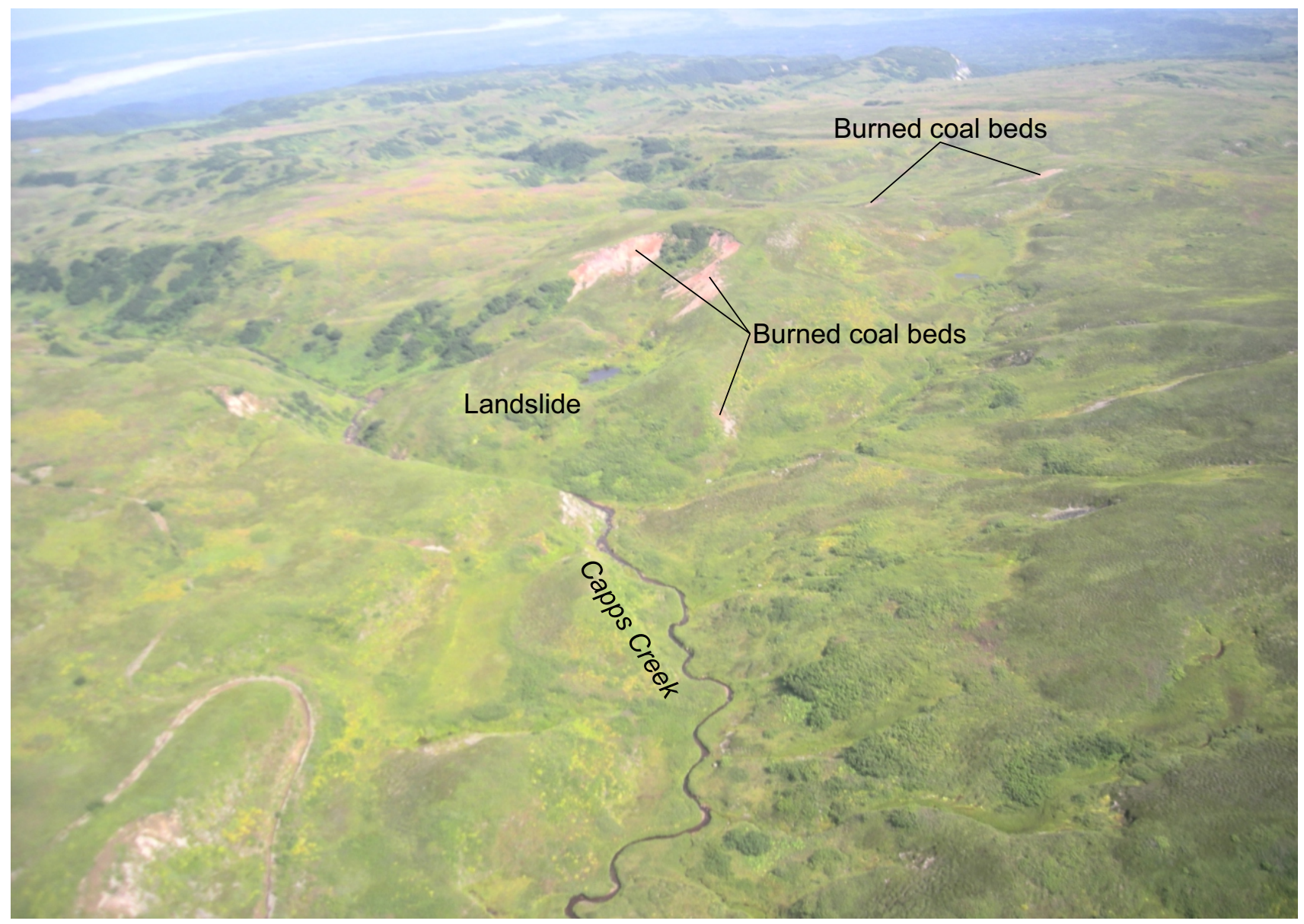

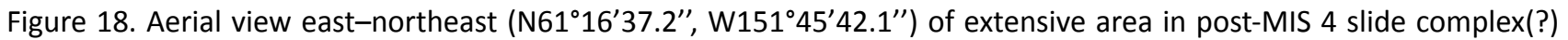
underlain by oxidized fine-grained sedimentary rocks and clinkers thought to result from burning of thick Capps coal and underlying coal beds in Tyonek Formation (Barnes, 1966, p. C25). Area located in Figure 16. Photograph taken 08/09/2011 by R.D. Reger.

\section{CHAKACHATNA VALLEY DEBRIS AVALANCHE}

Riehle (1985) first recognized the massive debris-avalanche deposits along the Chakachatna River (sheet 1) as well as the prominent southeastern breach in the Mount Spurr edifice. Nye and Turner (1990) initially tied the formation of the ancestral caldera, in which the Spurr volcanic complex later accumulated, and the debris avalanche to a massive collapse of the volcanic edifice. Subsequently Waythomas $(2001,2007)$ examined the debris avalanche and associated sediments, recognized that the debris avalanche deposits and associated clay-rich lahar sediments are genetically related, and proposed a mid-Holocene age for caldera formation and emplacement of the debris avalanche and lahar sediments.

The debris avalanche deposit extends $\sim 22 \mathrm{~km}$ from the lower end of the $\sim 5$-km-wide breach in the southern flank of the Mount Spurr edifice southeastward down the Chakachatna River valley to the western margin of the ChakachatnaMcArthur Embayment, where it terminates at the head of the broad alluvial fan that occupies the embayment (sheet 1)
(Waythomas, 2001, 2007; Waythomas and Nye, 2002). The present maximum proximal width of the avalanche tongue after post-emplacement erosion by the Chakachatna River is $\sim 3.2 \mathrm{~km}$. The deposit varies from $\sim 150 \mathrm{~m}$ to $\sim 300 \mathrm{~m}$ thick, covers $\sim 62 \mathrm{~km}^{2}$, and the volume is estimated to have been $\sim 4.60-4.65 \mathrm{~km}^{3}$ (Waythomas, 2001; Waythomas and Nye, 2002). The surface of the debris tongue is hummocky with local relief up to $\sim 30 \mathrm{~m}$; many of the hummocks are cored by huge andesite blocks. Waythomas (2007) recognized four facies in the debris-avalanche deposits: (1) blocks, rubble schlieren ${ }^{12}$, and coarse, angular avalanche debris; (2) altered blocks with little intervening matrix and outcrop-scale block-against-block texture; (3) a mixed facies of blockcored hummocks surrounded by granular matrix sediment; and (4) poorly sorted, granular, matrix-supported volcanic debris, sand, silt, and clay that grade downvalley into a clayrich lahar deposit.

Numerous exceptionally large andesite blocks measure up to several hundred meters across, and many are geochemically related to ancestral Mount Spurr lavas (Waythomas, 2007, fig. 7). From 60 to 80 percent of the rock debris is 
hydrothermally modified to variable degrees, ranging from slightly altered andesite to intensely altered hydrothermal clays. Lahar deposits contain pods and lenses of hydrothermal clay and altered rock debris, clasts of andesite from Mount Spurr, and subrounded cobbles and pebbles of lightgray, slightly vesicular pumiceous material (Waythomas, 2007). Recognizing decollement structures and lenses of hydrothermally modified volcanic material in the avalanche deposit, Waythomas (2007) concluded that the lahar deposits evolved from the debris-avalanche deposit. Clearly, the avalanche matrix must have been wet during emplacement. He dated wood buried during deposition of the lahar sediments and thus indirectly dated the debris avalanche from which the lahars were derived at $4,040 \pm 70$ to $4,230 \pm 50{ }^{14} \mathrm{C} \mathrm{yr} \mathrm{BP}$ (table 3, RC-2 and RC-3). The validity of those radiocarbon ages is reinforced by the presence of the distinctive Hayes tephra overlying the lahar deposits along Straight Creek. This regionally important tephra complex was erupted from Hayes volcano, a deeply eroded, snow- and ice-covered vent on the upper north flank of Mount Gerdine $\sim 80 \mathrm{~km}$ north-northwest of Mount Spurr in the northern Tordrillo Mountains (sheet 1), and was deposited in a series of radiating lobes (Riehle and others, 1990; Riehle, 1994; Waythomas and Miller, 2002). The southern lobes, which were deposited in the vicinity of Mount Spurr, date from $\sim 3.3$ to $\sim 3.7{ }^{14} \mathrm{C}$ kya (Riehle, 1985; Riehle and others, 1990; Combellick and Pinney, 1995).

Our mapping identifies a Holocene moraine deposited by Straight Creek Glacier on the massive debris-avalanche deposit at the head of Straight Creek in the vicinity of two sites where Waythomas (2007) collected wood beneath the clayey lahar deposits (sheet 1). This advance of Straight Creek Glacier blocked a small basin to the west, where undated lake sediments accumulated. A reasonable interpretation of the section along Straight Creek is that wood beneath the clayey lahar deposits overlies outwash of an earlier glacial advance and provides a minimum age for an advance of Straight Creek Glacier prior to $\sim 4,000-4,200{ }^{14} \mathrm{C}$ yr ago, close to the minimum age of 3,540 $\pm 60{ }^{14} \mathrm{C}$ yr BP for the Chichantna River moraine of Capps Glacier (RC-1 in table 3 and sheet 1). This interpretation also implies that the clayey lahar sediments related to the massive debris avalanche event by Waythomas (2007) must postdate that event and could result from a different lahar episode.

Although the exact mechanism for the formation of the Mount Spurr avalanche caldera and the massive debris avalanche in the Chakachatna River valley remains conjectural (Waythomas, 2007), sudden failures of the flanks of volcanic edifices are known to produce breached calderas associated with massive debris avalanches (Crandell, 1989). Two models of edifice destabilization and collapse are believed primarily responsible for this catastrophic process: (1) shallow intrusion into the volcanic edifice by magma with consequent explosive releases of highly pressurized gases (Bezymianny model) and (2) gradual structural weakening and destabilization of the volcanic pile by long-term hydrothermal alteration (Bandai model) (Siebert, 1984). Examination of the Mount Spurr area has failed to locate widespread evidence of the long-term post-paroxysmal plinian eruption activity such as blankets of ashflow tuff typically associated with powerful Bezymianny-type eruptions (Siebert, 1984). However, the Mount Spurr volcanic dome and edifice resulted from magma expulsions after formation of the avalanche caldera, and some local thin, unwelded, or partially welded pyroclastic-flow deposits have been produced by Holocene eruptions of the Crater Peak satellite vent and overlie the debris-avalanche deposit (Riehle, 1985; Nye and Turner, 1990; Waythomas, 2007; Waythomas and Nye, 2002). There is also considerable evidence of hydrothermal alteration of the Mount Spurr lavas, and four other local conditions also support a Bandai model there (Waythomas, 2007). First, the Mount Spurr edifice is precariously perched on a steeply dipping surface of granitic basement rocks (Waythomas and Nye, 2002). Second, the southern flank of the edifice is not buttressed for structural support. Third, the lowest exposed lava flows in the Mount Spurr volcanic complex date 255 kya (Nye and Turner, 1990), providing a long time for alteration of the lavas by hydrothermal groundwaters. Fourth, the probable conduits for deep-sourced hydrothermal waters entering the Mount Spurr edifice are the Capps Glacier thrust fault and parallel subsurface faults, which likely pass under the southern flank of the edifice in the granitic basement complex (Waythomas, 2007; Gillis and others, 2009; Garchar and Wendlendt, 2012). Thus, the evidence indicates that the Bundai model is most appropriate for massive collapse of the Mount Spurr edifice and release of the associated massive debris avalanche.

The mid-Holocene age of the massive debris avalanche implies that deep scouring of the southern flank of the Mount Spurr edifice by ice flowing through the Chakachatna River valley during the last major glaciation and subsequent loss of lateral support when the ice retreated were significant contributing factors (Cossart and others, 2008). Another possible contributing influence could have been gravitational spreading of the Mount Spurr edifice, which eventually achieved an unstable configuration (Shirzaei and others, 2011). Ultimately, a strong local earthquake could have been the triggering event (Harp and others, 2003).

\section{KALOA DEPOSITS NEAR GRANITE POINT}

Although previous investigations of the origin and age of the Kaloa deposits exposed in the coastal bluffs in the vicinity of Granite Point in northwestern Cook Inlet (fig. 1) have reached different conclusions, the most recent investigation indicates that the Kaloa deposits represent a local, late facies of the Bootlegger Cove Formation (Reger, 2009). Schmoll and Yehle (1978, fig. 38) initially mapped deposits in the Granite Point area as older morainal deposits of Pleistocene age. Later, Schmoll and others (1984, p. 53-64) described and illustrated the 110-m-thick stratigraphic package of diamictons, coal, and sandstone exposed in the coastal bluff between Granite Point and Beshta Bay, stressed its unique character compared to other bluff exposures around Cook Inlet, and informally named the Kaloa deposits after a nearby well in the Albert Kaloa gas field to the northwest (Haeussler and Saltus, 2011). Because Miocene pollen is present in the coal in the coastal bluff, Schmoll and others (1984, p. 62) favored an autochthonous origin for the coal, correlated it 
with the nearby Beluga Formation, and chose a Tertiary age for the Kaloa deposits. They also suggested that the diamictons that dominate the bluff face could correlate with subsurface "tillites" identified by Boss and others (1976) in wells penetrating the Sterling and Beluga Formations in the northern Kenai Peninsula Lowland to the east and proposed that they could be evidence for multiple glaciations of late Tertiary age in the Cook Inlet basin.

Haeussler and others $(2000$, p. 1,421-1,422) favored an allochthonous origin for the prominent coal bed at Granite Point, emphasizing that the coal lacks depositional contacts, is sheared along its margins, and consists of internally disrupted and randomly oriented coal clasts. They further pointed out that the scattered coal clasts in the diamictons clearly indicate that the coal was lithified prior to its deposition in the diamictons, implying a considerable difference in age, and they concluded that the Kaloa deposits are Pleistocene in age.

Reger (2009) and his colleagues reassessed the Kaloa section, incorporated depositional models for diamictons that have proven appropriate elsewhere in the Cook Inlet basin, and correlated the Koala deposits with the Bootlegger Cove Formation of late Pleistocene age elsewhere in the Cook Inlet region.

\section{Coastal bluff section}

The coastal bluff in which the Kaloa deposits are exposed stands $40-43 \mathrm{~m}$ above the beach from Granite Point northeastward for $\sim 1.5 \mathrm{~km}$ to Beshta Bay (fig. 19). The bluff section is divided in half by a prominent gully traversed by a petroleum pipeline that connects storage and pumping
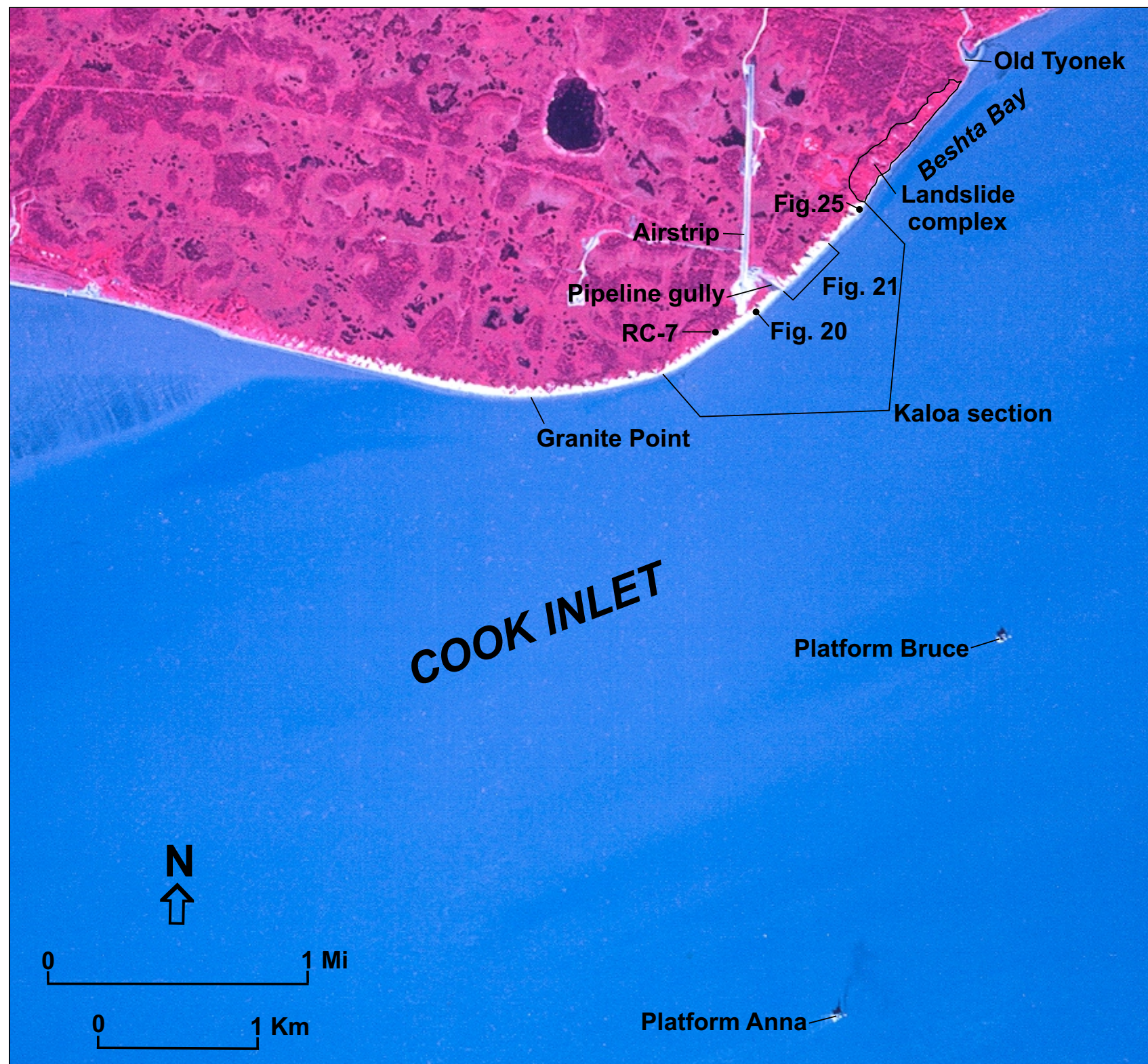

Figure 19. Vertical false-color infrared aerial photograph, showing location of Kaloa section, locations of text figures, and petroleum infrastructure in Granite Point area (fig. 3). RC-7 = radiocarbon locality collected by Haeussler and others (2000) (table 3) (Alaska High Altitude Photograph ALK 60 CIR 6479 taken August 1978). 
facilities on the west side of Cook Inlet with refineries at Nikiski (Magoon and others, 1976, pl. 1). Southwest of this gully, stratigraphy in the coastal bluff is fairly simple. A more complex section is exposed to the northeast. A fairly continuous colluvial apron along the bluff base obscures the lowermost strata, complicating mapping and interpretation. The Kaloa deposits are dominated by a succession of medium- to dark-gray autochthonous diamictons with variable dropstone contents. A younger, distinctive tan-gray to medium-gray diamicton of fairly uniform thickness in the uppermost 4-7 $\mathrm{m}$ of the bluff was identified as drift of the Nikolai moraine by Schmoll and others (1984, fig. 9A) and was considered to be either middle or middle late Wisconsinan in age (Schmoll and Yehle, 1986). The upper meter or so of this diamicton consists of rippled sands and tidal silts without dropstones, indicating shallow inlet conditions without the presence of glacial or shelf ice. Discontinuously capping the bluff is a 1-2-m-thick freshwater peat, which has a basal radiocarbon age of $12,250 \pm 90{ }^{14} \mathrm{C}$ yr BP (table 3, RC-7). The apparent dip of the Kaloa deposits in the plane of the bluff face is as shallow as $\sim 2-4$ degrees southwest in the southwestern half of the bluff and as much as $\sim 6-7$ degrees southwest in the northeastern half. Thus, older Kaloa units crop out close to Beshta Bay and progressively younger Kaloa units are exposed southwestward along the coast.

The southwestern coastal bluff consists almost entirely of medium-gray autochthonous diamictons associated with numerous lines of dropstones that mark the intersection of the bluff face with lags left on the former inlet floor by bottom-scouring currents that were probably active beneath floating glacial ice (Eyles and McCabe, 1989, fig. 7-4) (fig. 20). Dropstones, dominantly of volcanic and granitic lithologies derived from the Alaska Range to the northwest, vary in abundance and reach a maximum diameter of $\sim 2 \mathrm{~m}$. Numerous angular cobbles and boulders of clastic coal are present among dropstones scattered throughout the diamictons exposed in the bluff face.

The northeastern coastal bluff is dominated by mediumgray diamictons, which are mostly dropstone rich, but lines of dropstones are generally absent. The lower bluff is traversed by a conspicuous dark-gray layer of allochthonous coal that pinches out $\sim 265 \mathrm{~m}$ northeast of the pipeline centerline (fig. 21). Although the 1.5-2-m-thick coal looks like a coherent bed from a distance, its allochthonous origin is clearly



Figure 20. View northwest of coastal bluff near Granite Point (N61 $00^{\prime} 59.8^{\prime \prime}$, W151 $\left.11^{\prime} 43.2^{\prime \prime}\right)$, showing lines of dropstone lags formed by scouring inlet-bottom currents between rainout diamictons in glacioestuarine sediments. Note lack of dropstones in upper section. Geologist provides scale. Photograph taken 08/23/2007 by D.L. LePain. 
demonstrated by the intensely fractured nature of the bed, which is composed of angular, blocky to platy chunks of coal up to $30 \mathrm{~cm}$ in diameter, pieces of coherent sandstone (some with fragments of coalified fossil wood that are typical of channel fills in the Beluga Formation), and angular to irregular masses of pebble diamicton (fig. 22). These fragments are suspended in a matrix of crushed coal chaotically mixed with lenses and layers of fine- to medium-grained, structureless sand. The presence of crushed coal and structureless sand between chunks of coal and sandstone indicates that the two formed a slurry during emplacement of the coal bed. Typically, the disrupted coal is in abrupt contact with an overlying clay-silt diamicton with numerous dropstone pebbles. Abruptly underlying the coal bed is a distinctive, gray $(7.5 \mathrm{YR} 6 / 0)$, fine to medium sand with 1-2-mm-thick lenses of crushed coal. This sand bed is at least $1 \mathrm{~m}$ thick and dries white (10YR8/1). We suggest that the apparent coherent, bed-like character of the disrupted coal is a function of its mode of deposition as a discrete subestuarine slide, which probably slid on the underlying sand that was saturated and acted as a lubricating slurry. The presence of Miocene pollen in the coal fragments and the nearby exposures of coal beds in the Beluga Formation (Barnes, 1966, pls. 5 and 7, sections 166-177) indicate the source of the landslide.

Stratigraphically lower and separated from the disrupted coal and its associated underlying sand by a dropstone-rich diamicton is a distinctive, $\sim 2$-m-thick, light-colored, fairly massive, allochthonous sand probably formed by intensive fracturing and pulverizing of sandstone units in the nearby Beluga Formation (fig. 23). The sand is clearly not mixed with diamictons that enclose the deposit. Schmoll and others (1984, fig. 9A) mapped this deposit as sandstone, but the unit is clearly not lithified. In the vicinity of station $263 \mathrm{NE}$ (fig. 21) the sand is underlain by a series of silt-rich diamicton layers up to $12 \mathrm{~cm}$ thick that contain pebble-sized pieces of dark gray-brown claystone. This claystone is typically interlayered with sandstones in the Beluga Formation in this part of Cook Inlet basin ${ }^{13}$, indicating that both the sand and silt units represent reworked Beluga Formation. The lack of mixing of both units with surrounding diamictons indicates that the period of their emplacement was brief.

Supporting evidence for the Beluga Formation as the source of the allochthonous beds is found $\sim 45 \mathrm{~m}$ farther northeast, where pebbly sand contains small lenses of clay with some silt and sand and scattered small cobbles of siderite, which typically forms concretions in the Beluga Formation. The moist color of the sand there is light olivegray $(2.5 \mathrm{Y} 5 / 4)$ to yellowish-brown (10YR5/6), and the sand comprises the upper part of a series of 30-40-cm-thick beds that individually grade from pebble gravels upward into sands. The presence of siderite nodules in these sands and their graded character indicate that these units were derived from the Beluga Formation and were likely deposited on the inlet bottom by a series of subestuarine density flows.

Near station $355 \mathrm{NE}$ (fig. 21) a tan layer of fine- to medium-grained sand overlies a chaotically bedded, tan-gray mass of mixed pebbly sand, silt, and dropstone diamicton (fig. 24). The sand bed, which encloses a blocky siderite concretion, could represent a density flow deposit or a dike related to liquefaction after deposition of the lower diamicton, which is

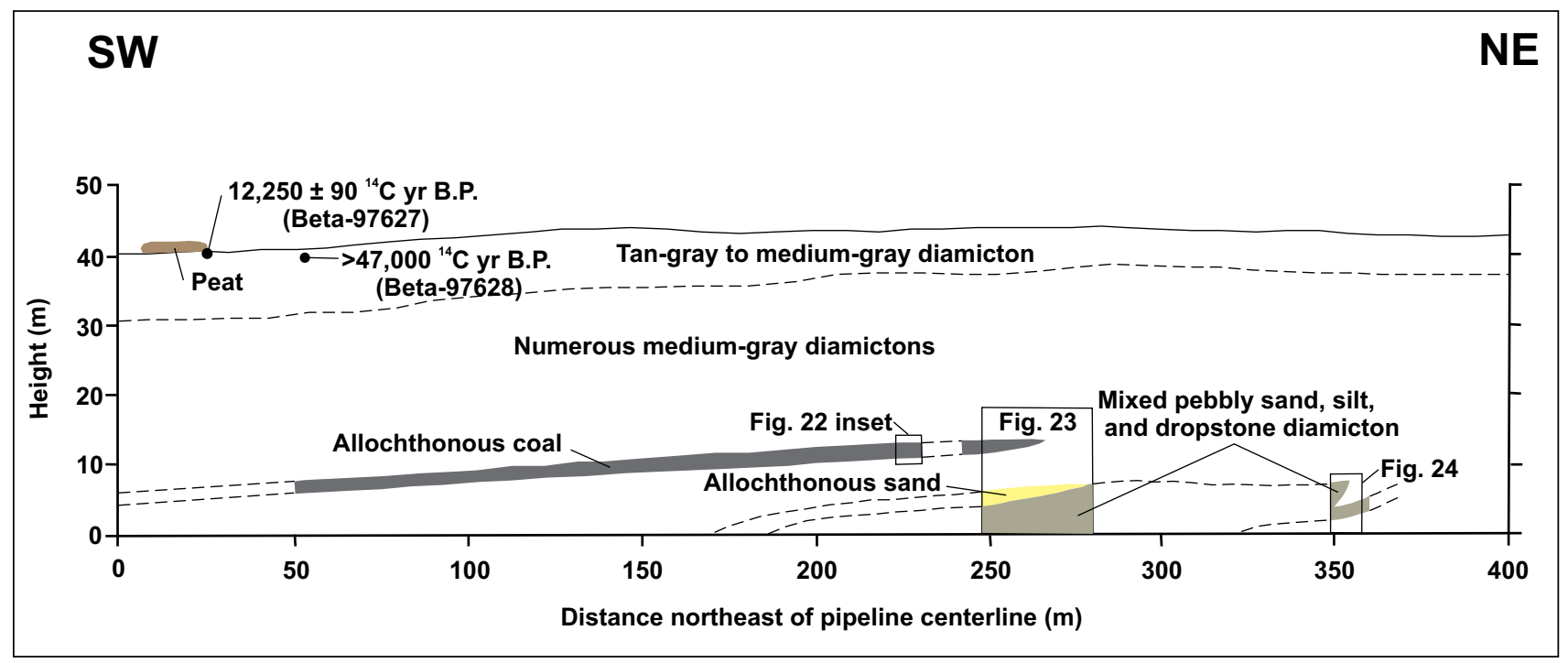

Figure 21. Sketch of section exposed northeast of pipeline in coastal bluff at Granite Point. Vertical exaggeration $=2$. Much of lower section is obscured by colluvial apron. Radiocarbon ages from Haeussler and others (2000) projected from southwestern section (fig. 19).

\footnotetext{
${ }^{13}$ The Sterling Formation of Pliocene age, which overlies the Beluga Formation elsewhere in the Cook Inlet basin, is not present in the Granite Point-Beshta Bay area and is probably not the source of the allochthonous beds (L. Silliphant, September 16, 2008, written commun.). The weakly lithified Sterling Formation was likely removed by intense glacial scouring in this area prior to deposition of the Kaloa beds.
} 
the stratigraphically lowest and oldest allochthonous deposit exposed in the bluff section.

Farther northeast, the section exposed in the high bluff at the southwestern limit of Beshta Bay displays numerous complex diamictons interlayered with planar sand beds (fig. 25). These autochthonous sediments document deposition of subestuarine flows, slides, and rainout diamictons on the former inlet floor prior to deposition of the younger, allochthonous Kaloa beds to the southwest. Thin sand beds were deposited by bottom currents between episodes of diamicton deposition when ice-proximal turbid plumes shifted locations, or glacial or shelf ice drifted away from the site. Apparent flowage of mass-movement units in the section indicates that the inlet bottom sloped southwest.

\section{Beshta Bay landslide complex}

In Beshta Bay a complex of large onshore landslides displaces and exposes the Beluga Formation and produced tilted blocks of fossiliferous sandstone, siltstone, and coal in the intertidal zone (fig. 19). Our brief examination of headwall scarps and deformed slide deposits close to and along the beach convinced us that their state of preservation is the same as translational and rotational slides that occurred in the
Anchorage area during the Great Alaska Earthquake of March 27, 1964 (Hansen, 1965). Schmoll and others (1981, p. 102) briefly mentioned active failures of the Beluga Formation along the shore of Beshta Bay in the southeastern corner of the map area (fig. 3), and Schmoll and others (1984, p. 60) suggested that radiocarbon ages $<200{ }^{14} \mathrm{C}$ yr BP and counts of growth rings in curved trees are evidence that landsliding continues. Although the 1964 Great Alaska Earthquake could have produced the large onshore landslide complex in the Beshta Bay area, alternative explanations include removal of underlying support by wave erosion and shaking originating along local seismic sources.

\section{Age and depositional model}

Clearly, the Granite Point-Beshta Bay bluff section is older than the $12,250 \pm 90{ }^{14} \mathrm{C}$ yr BP age of the basal peat at the top of the section. Early misinterpretation of the bluff section north of Kenai by Karlstrom (1964, pl. 6) was based on several infinite radiocarbon ages for reworked Tertiary wood in much younger glaciofluvial deposits (Reger and others, 2007, fig. 53). We believe that the single infinite radiocarbon age of $>47,000{ }^{14} \mathrm{C}$ yr BP (Haeussler and others, 2000, table 2, Beta-97628) for wood found $1.2 \mathrm{~m}$ below the top

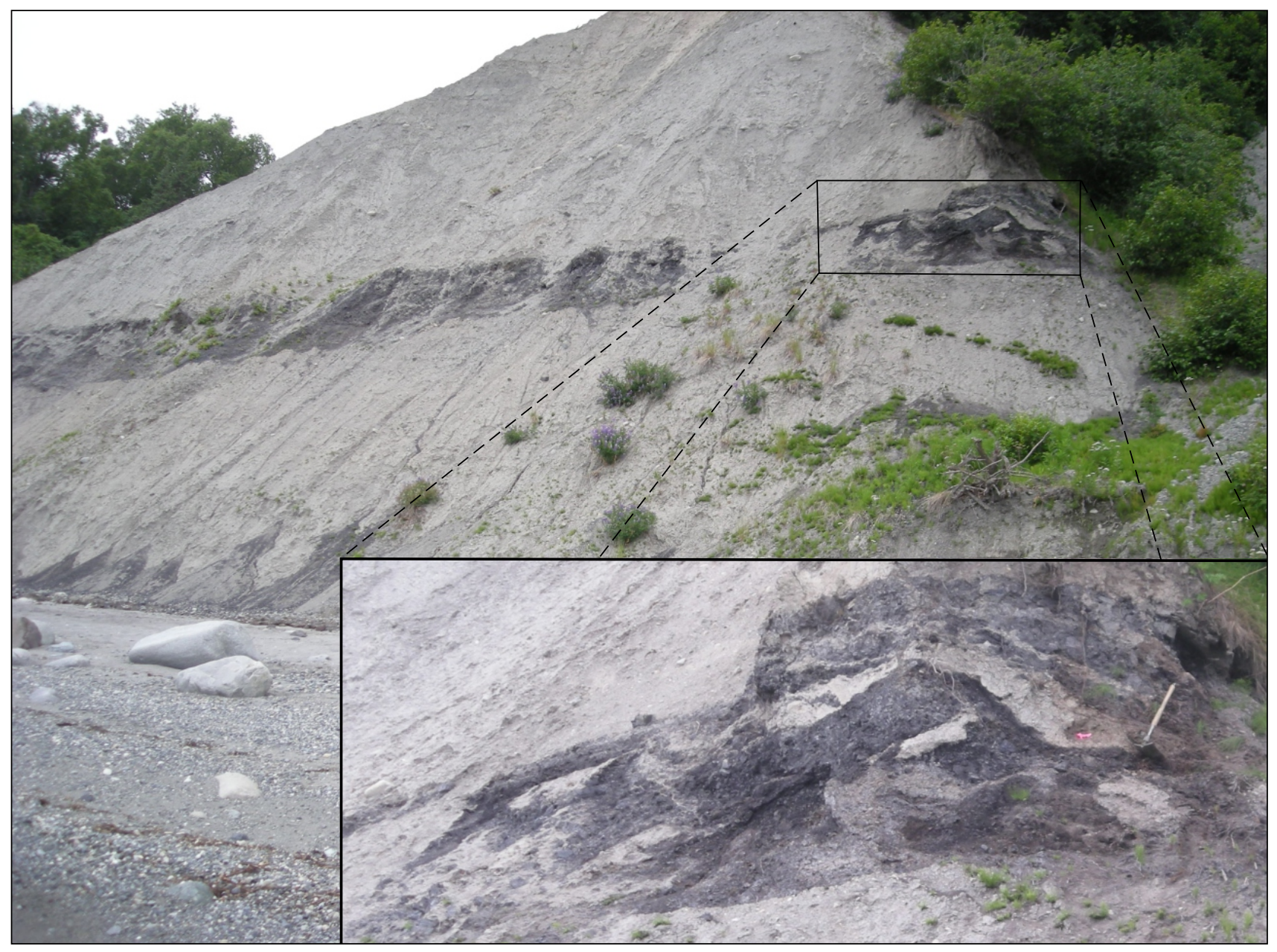

Figure 22. Prominent allochthonous coal bed exposed in coastal bluff 150-230 m northeast of pipeline (N61 $01^{\prime} 07.7^{\prime \prime}$, W151 $\left.19^{\prime} 25.6^{\prime \prime}\right)$. Inset shows intensely fractured, pulverized, and distorted coal mixed with pebble diamicton. Shovel handle is $0.5 \mathrm{~m}$ long. Photograph taken $07 / 15 / 2008$ by R.D. Reger. 


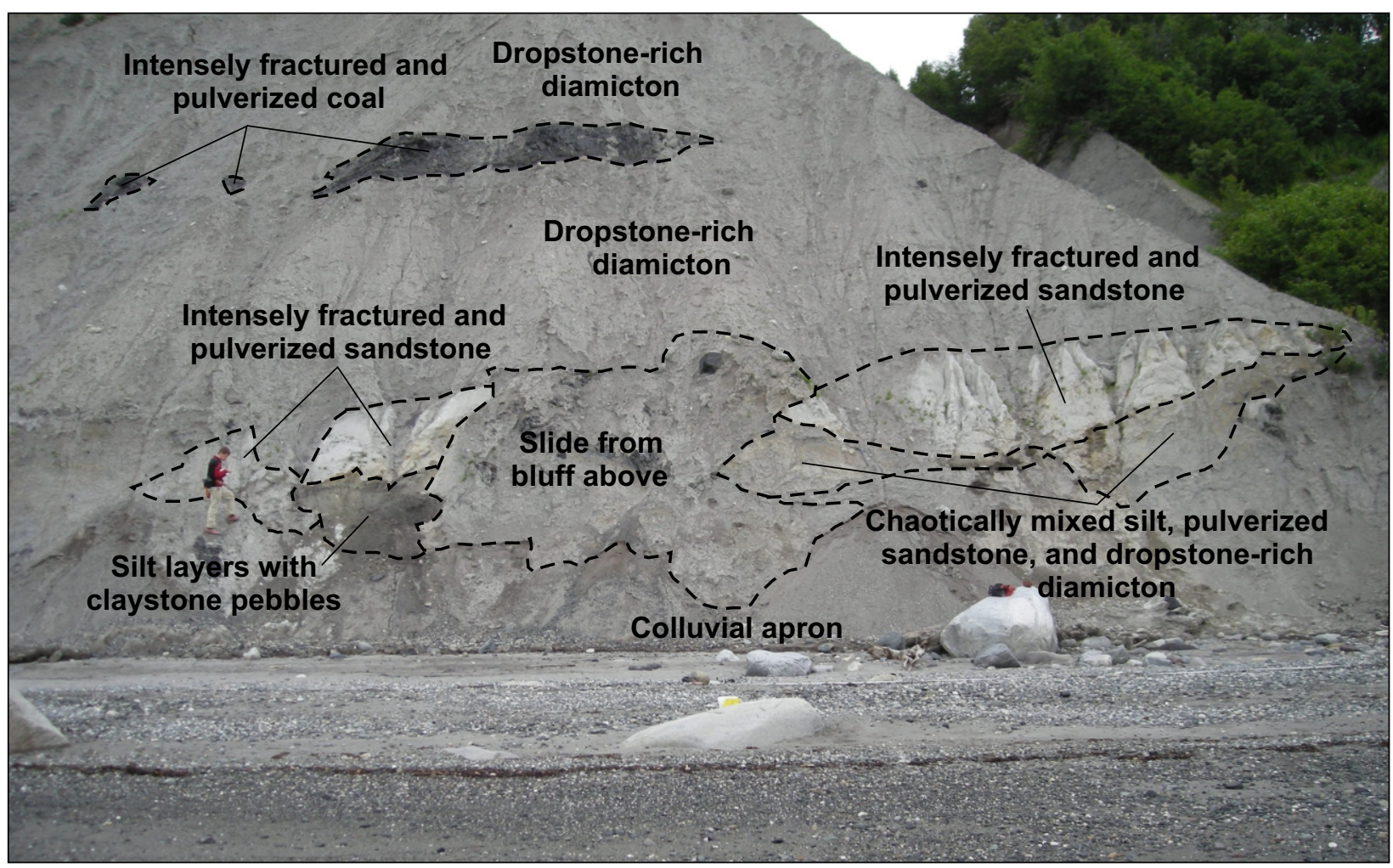

Figure 23. Principal stratigraphic units exposed in coastal bluff $263 \mathrm{~m}$ northeast of pipeline (N61 $01^{\prime} 12.2^{\prime \prime}$, W151 $19^{\prime} 20.2^{\prime \prime}$ ), partially obscured by slope colluvium. Geologist provides scale. Photograph taken $07 / 16 / 2008$ by R.D. Reger.

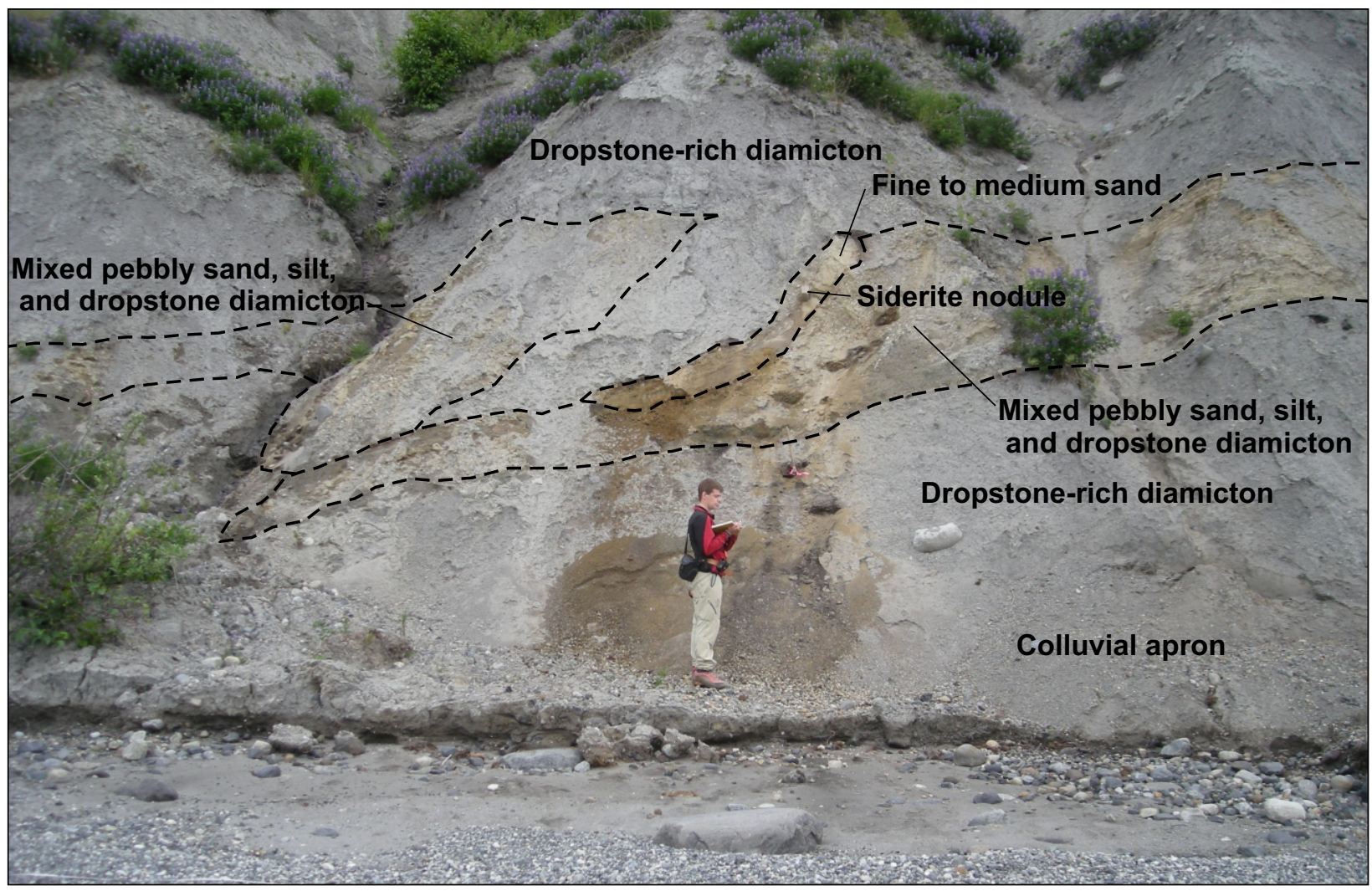

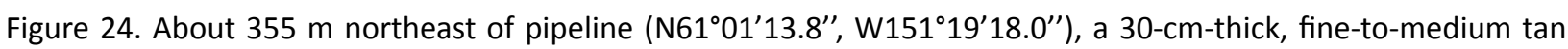
sand containing clasts of siderite overlies a tan-gray, complexly bedded pebbly sand, silt, and dropstone diamicton sandwiched between massive, medium-gray, dropstone-rich, rainout diamictons. Geologist provides scale. Photograph taken $07 / 16 / 2008$ by R.D. Reger. 




Figure 25. Complexly deformed autochthonous diamictons interlayered with sand beds in coastal bluff at southwestern

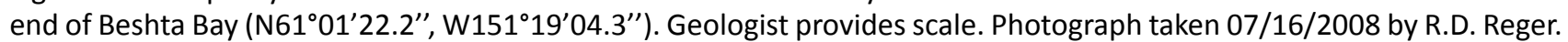

of the Granite Point section (fig. 21) does not reflect the age of the enclosing sediments. Our diligent search of the bluff section identified no potentially datable calcareous shells or plates of pelecypods, gastropods, or barnacles, such as those found in similar diamictons in the Anchorage-Turnagain Arm area and at Kenai and Kalifornsky along the western coast of the Kenai Peninsula (Reger and others, 1995, 1996). This absence of datable material forces use of less accurate, indirect dating of the Kaloa deposits by relating the sequence of events in the Granite Point area to events elsewhere in the Cook Inlet region.

A key indicator of the general age of the Kaloa sequence is the lack of evidence in the section for grounding of glacial or shelf ice in the Granite Point area. None of the diamictons exhibit the intense deformation or sediments typical of morainal-bank complexes that would be produced by contact of glacial ice with the inlet bottom (Eyles and McCabe, 1989, fig. 10; Reger and others, 2007, figs. 53 and 55). Except for mass-movement deposits, diamictons in the section accumu- lated rapidly as rainout deposits beneath floating tidewater glaciers, ice shelves, or ice-proximal turbid plumes ${ }^{14}$. The diamicton that was mapped across the top of the section as Nikolai ground moraine by Schmoll and others (1984, fig. 9A) is glacioestuarine, not a morainal deposit. Deep inlet conditions and an isostatically depressed inlet floor existed in this area during deposition of most of the Kaloa section, and tidewater glaciers or ice shelves were thin enough to float freely (fig. 26). The lack of dropstones and the presence of estuarine and tidal-flat sediments at the top of the Kaloa section (fig. 20) indicate that tidewater glaciers and ice shelves were gone by that time and that shoaling and emergence of the rebounding inlet bottom occurred late in the sequence of events. Those conditions likely existed during the latest Skilak and Elmendorf stades of the Naptowne glaciation, approximately 16,500-11,000 yr ago (Reger and others, 2007, fig. 6). Therefore, the environment of deposition and estimated age of the Kaloa section indicate correlation with younger Bootlegger Cove Formation facies in the upper

\footnotetext{
${ }^{14}$ Rates of sedimentation proximal to tidewater glaciers are typically high (Cowan and Powell, 1991). We suggest that deposition was sufficiently rapid beneath former tidewater glaciers, ice shelves, or turbid plumes in the Granite Point area that benthic organisms could not survive, perhaps explaining the absence of their remains in the deposits there.
} 


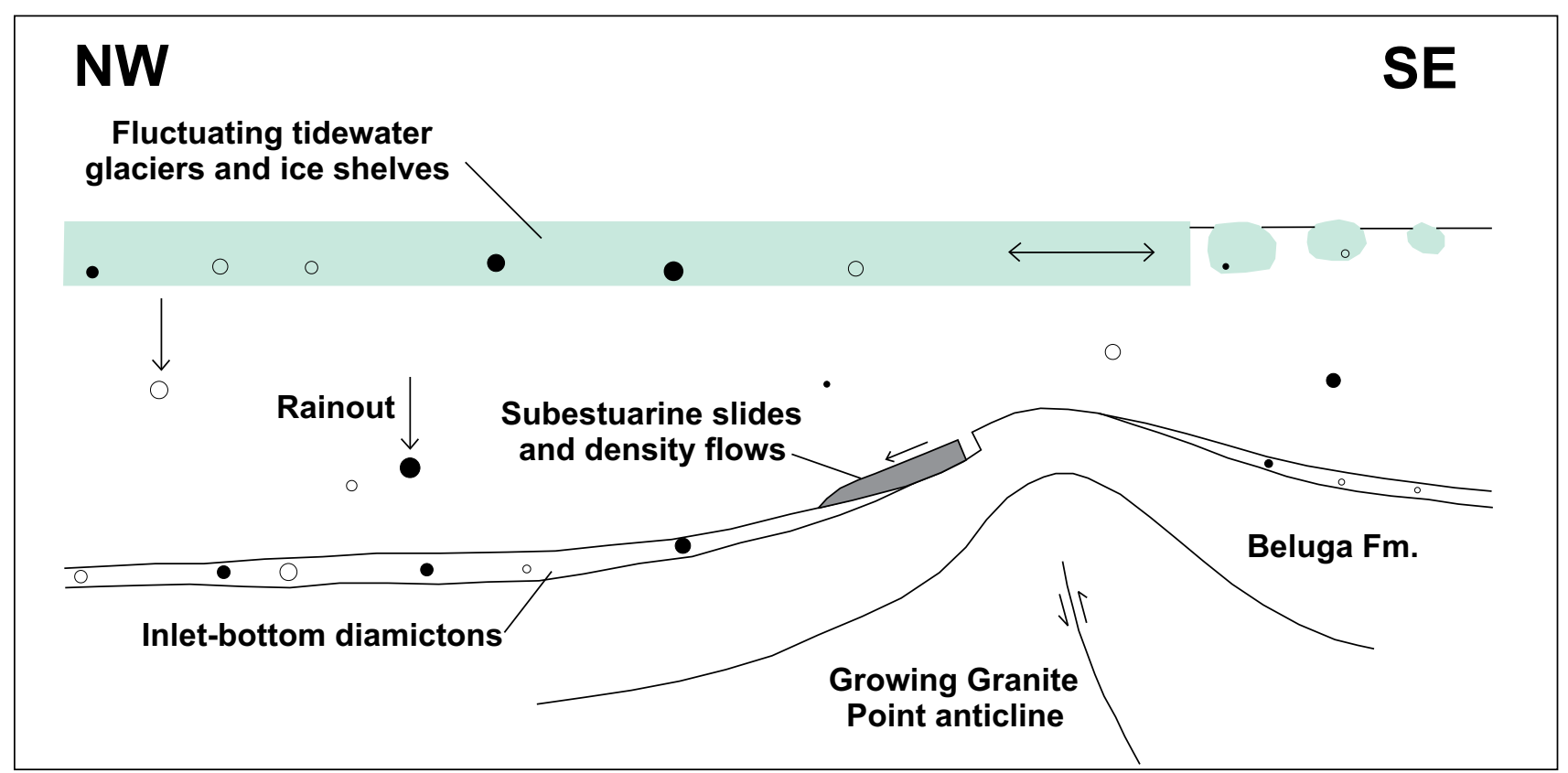

Figure 26. Model showing environment beneath fluctuating tidewater glaciers and ice shelves during subinlet deposition of Kaloa sediments on western flank of growing Granite Point anticline in Granite Point-Beshta Bay area.

Cook Inlet region, including the locality along lower Beluga River (Schmoll and others, 1972, 1984, 1999; Reger and others, 1995), and postdates older facies of the Bootlegger Cove Formation in the Kenai-Kalifornsky area (Reger and others, 1996, 2007).

The proximity of the Granite Point-Beshta Bay area to the Granite Point anticline has long been recognized (Magoon and others, 1976, pl. 1; Schmoll and others, 1984, p. 58). Offshore platforms Bruce and Anna tap oil that has accumulated in that structure (fig. 19). Beluga Formation is exposed in the headwalls of onshore landslides in the Beshta Bay area on the western flank of the Granite Point anticline. Haeussler and others (2000, fig. 7) attributed dipping strata in the Kaloa package on the western flank of the anticline to growth of the structure. Large onshore landslides in the Beshta Bay area demonstrate that the near-surface Beluga Formation there is susceptible to slope failure.

At a time when the floor of Cook Inlet was isostatically depressed and tidewater glaciers and associated ice shelves related to the Chakachatna-McArthur Embayment floated in the Granite Point area, we believe that near-surface beds of the Beluga Formation may have been severely shaken and dislodged at least twice, triggering subestuarine slides and density flows that moved rapidly down the western flank of the Granite Point anticline. Potential sources of this episodic, locally intense shaking include movements along the thrust fault in the growing Granite Point anticline (Haeussler and others, 2000) (fig. 24), displacements along other local structures including the Castle Mountain-Lake Clark fault (Koehler and Reger, 2011), and distant sources related to the Aleutian megathrust.

\section{LAKE CLARK FAULT}

Following the precedent set by Detterman and others (1976), we place the trace of the Lake Clark fault along the 5-km-long, 20-25-m-high, linear scarp in exposed granitic bedrock across the southeastern flank of Lone Ridge $(\text { sheet } 1)^{15}$. The fault is expressed there as a narrow zone of crushed granitic bedrock along which several springs emerge. At Lone Ridge, we failed to find definitive evidence that the Blueberry Hill (MIS 6?) drift or the Upper Chuitna (MIS 4) moraine, which thinly blanket Lone Ridge and occupy the lowland to the southeast (sheet 1), are offset along the Lake Clark fault, but could not rule out that possibility (Koehler and Reger, 2009). The drift sheets could simply be draped over a pre-existing fault scarp.

To the northeast, the fault scarp becomes subtle with rounded morphology and is hidden by dense vegetation (fig. 27). Schmoll and Yehle (1987) inferred that the fault offsets early late Wisconsinan moraines there, but offered no definitive evidence to support their statement. Our investigations identified no evidence of vertical or lateral offset of the Naptowne moraines in that area. To the southwest, Barnes (1966, pl. 5) mapped offset of the Tyonek Formation and drag folds demonstrating uplift of the northwestern block along the vertical fault in the deeply incised upper Chuitna River valley. However, the Lake Clark fault trends without apparent offset across the Upper Chuitna (MIS 4) moraine in that segment, and neither the Chuitna River nor Chuit Creek are laterally offset along the fault trace. Nonetheless, profiles constructed from topographic maps along both channels show subtle convex-up morphologies, which could indicate

\footnotetext{
${ }^{15}$ Barnes (1966) identified this fault as the Castle Mountain fault. Schmoll and others (1981) called it the Lone Ridge fault and correlated it with the Lake Clark fault. All three faults have the same trends and same high-angle reverse displacements (Koehler and Reger, 2011).
} 


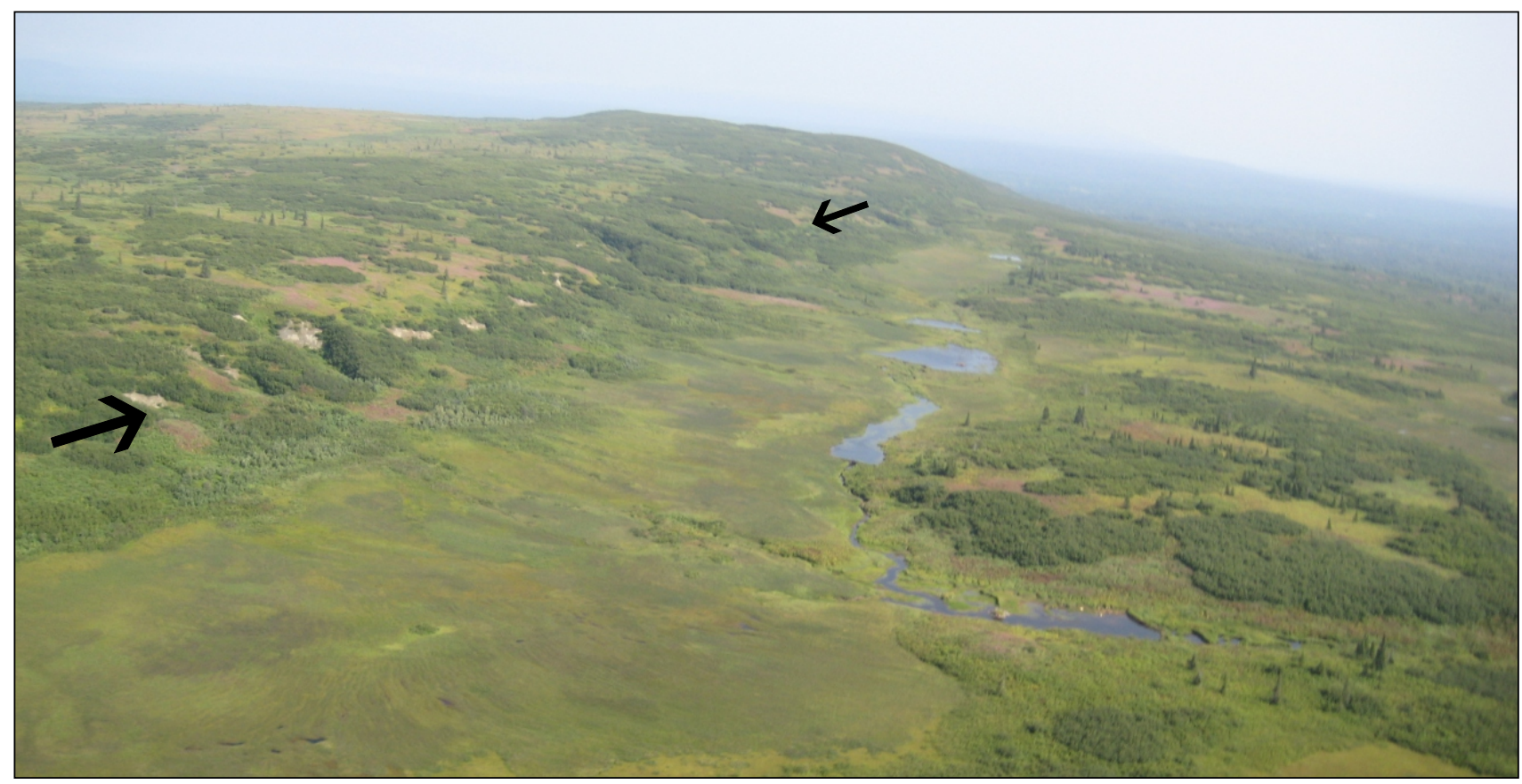

Figure 27. Aerial view northwest of 20-m-high Lone Ridge granitic escarpment (N61 ${ }^{\circ} 12^{\prime} 56.1^{\prime \prime}$, W151 $30^{\prime} 15.2^{\prime \prime}$ ), showing trend of Lake Clark fault between arrows. Photograph taken 08/09/2009 by R.D. Koehler.

northsideup deformation consistent with the bedrock scarp at Lone Ridge (Koehler and Reger, 2011, fig. 5). Farther southwest along the fault trend, the crests of Naptowne (MIS 2) lateral moraines deposited by ice in the Chakachatna-McArthur Embayment are apparently not laterally offset (sheet 1). We did not find evidence that the Lake Clark fault has offset the broad Holocene alluvial fan in the embayment.

The absence of offset of MIS 2 and MIS 4 moraines is evidence that the segment of the Lake Clark fault in the map area has not produced a surface-rupturing earthquake for at least $\sim 30$ ka since the beginning of the MIS 2 glaciation, and probably for $\sim 60 \mathrm{ka}$ since the penultimate (MIS 4) glaciation. Possible but undemonstrated offset of the thin MIS 6? drift sheet at Lone Ridge still leaves viable the possibility that north-side-up displacements occurred along the Lake Clark fault during the $\sim 130$ ka since the pre-penultimate glaciation.

\section{EVIDENCE OF MASSIVE FLOODS}

In the map area, evidence of flooding caused by the sudden release of impounded meltwaters is recognized in the Beluga, Chichantna, Chakachatna, and McArthur river drainages (Post and Mayo, 1971).

\section{BELUGA RIVER AND CHICHANTNA RIVER DRAINAGES}

The northern Beluga Plateau is drained by the Beluga River, a large glacial-meltwater stream with a history of recurrent floods that are released when Triumvirate Glacier, which blocks the Strandline Lake basin and impounds several other much smaller ice-marginal lakes (fig. 1), is bypassed through a complex of subglacial channels (Sturm, 1986; Sturm and others, 1987). The resulting meltwater surges pass across the Triumvirate Glacier outwash plain, through Upper and Lower Beluga lakes, which dampen the flood surges (Sturm and Benson, 1989), and down the Beluga River (Post and Mayo, 1971). Alluvial terraces and abandoned-channel gravels were deposited by massive Holocene outburst floods down the Beluga River in the northeastern corner of the map area (sheet 1). Past floods have washed out the approaches to the bridge over the Beluga River and pose a significant infrastructure hazard along the course of the river (Schmoll and others, 1981).

A large, pitted, granular alluvial fan, informally termed the Beluga expansion fan, is associated with flood-sculpted Threemile Creek moraine at the prominent bend in the lower Beluga River in the east-central map area (fig. 3, sheet 1). This expansion fan was deposited by the earliest known massive outburst flooding down the Beluga River. Pitting of the fan surface demonstrates that the flood expansion fan was deposited on stagnant glacial ice late in the Killey stade of the last major glaciation (table 1).

Mid-Holocene flood courses identified by abandoned channels now occupied by underfit Bishop and Scarp creeks extend from the Chichantna River moraine of Capps Glacier to the Beluga River (fig. 3, sheet 1). Likely sources of those flood waters are small, ice-marginal, meltwater basins such as the basins impounded by Capps Glacier today (Post and Mayo, 1971, sheet 2).

Exposures in the entrenched lower drainages of both Bishop and Scarp creeks display successions of deltaic foreset beds of sand and gravel that dip downstream (fig. 28), evidence that mid-Holocene flooding of the Beluga River produced slackwater conditions in both drainages. Deltaic sands contain tongues and beds of pebble gravel with detrital coal clasts. Soft-sediment deformation of sand beds indicates 


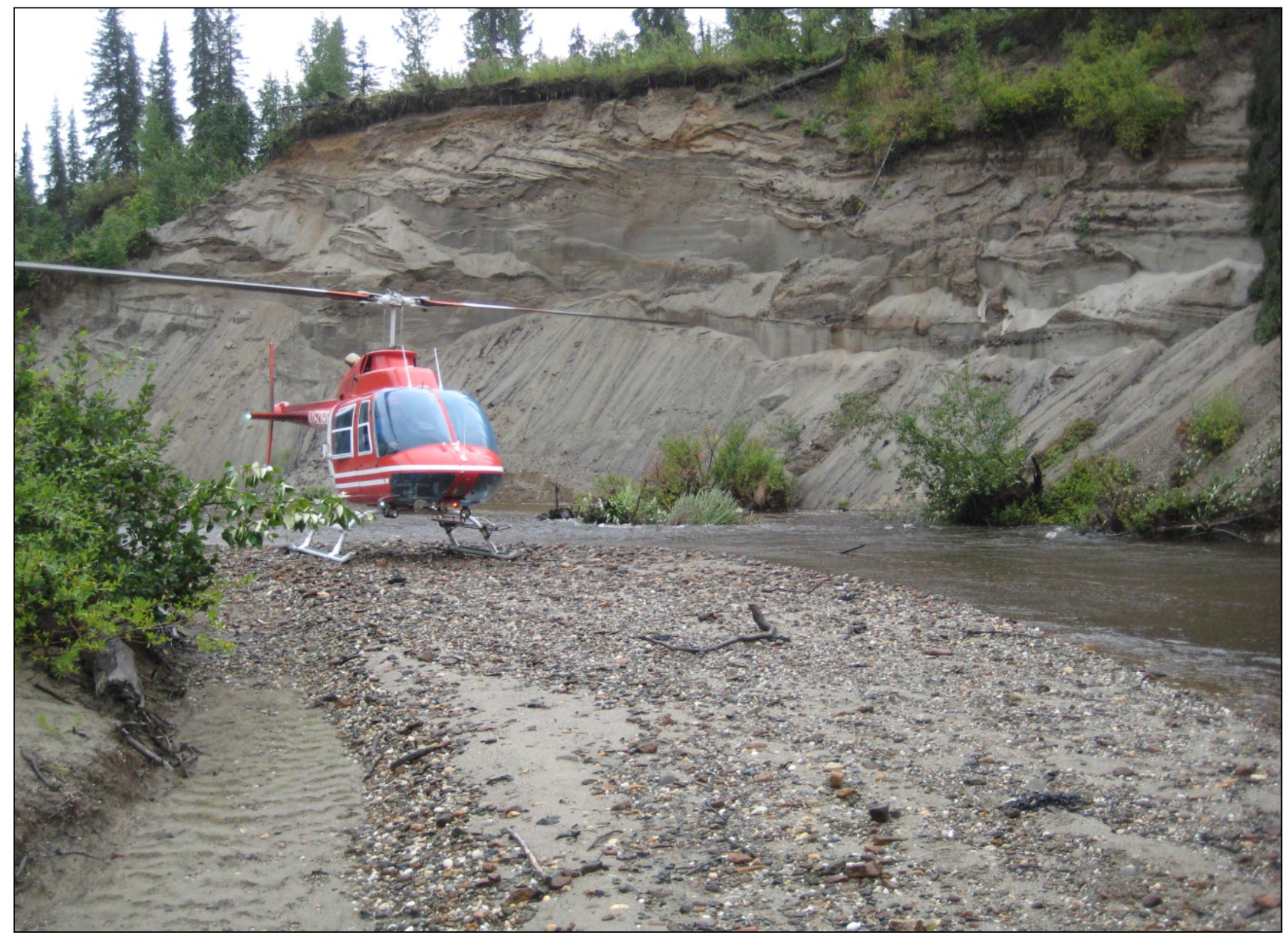

Figure 28. Exposure of deltaic sands dipping downstream in mid-Holocene flood channel of Scarp Creek, northeastern map area (N61¹7'00.4", W151¹9'56.5"). Helicopter provides scale. Photograph taken 08/15/2009 by R.D. Koehler.

that downstream progradation of deltas was rapid in flood channels. Near the junction with the Beluga River, finegrained slackwater rhythmites are exposed in low terraces along Bishop Creek.

\section{CHAKACHATNA RIVER DRAINAGE}

Mid-Holocene collapse of the southern sector of the Mount Spurr volcanic complex produced the previously described massive debris avalanche that dammed the Chakachatna River for $\sim 17$ km (Waythomas, 2001, 2007; Waythomas and Nye, 2002). Blocking of the upper Chakachatna River temporarily impounded a huge meltwater lake that extended upstream to incorporate Lake Chakachamna, eventually reaching a combined impounded volume of $\sim 6.73$ x $10^{9} \mathrm{~m}^{3}$ (Waythomas, 2001, table 2). The massive debris dam eventually failed by erosion along the southern margin, probably from a combination of upstream migration of a steep nickpoint and spillage of the impounded lake, cutting a 1.0-km-wide flood channel. Using equations developed for the dam-break model of Walder and O'Connor (1997), Waythomas (2001, table 2) estimated that maximum peak-flood discharges ranged from $\sim 11.9 \times 10^{3} \mathrm{~m}^{3} \mathrm{~s}^{-1}$ if breach erosion rates were relatively slow, to $\sim 7.9 \times 10^{6} \mathrm{~m}^{3} \mathrm{~s}^{-1}$ if breach erosion rates were relatively fast. Floods scoured debris from the massive avalanche deposit along the breach and spread it across the broad fan at the mouth of the narrow Chakachatna River valley, dropping coarse clasts in the proximal zone and depositing finer sediments in the distal zone. Eventually all of the proximal fan surface was covered by cobble gravel with scattered volcanic blocks, and at least 50 percent of the total alluvial-fan surface was inundated (Waythomas, 2001, fig. 12; Waythomas and Nye, 2002).

Stratigraphic evidence demonstrates that three or four noncohesive lahars were deposited in the $1.7 \mathrm{ka}$ prior to the 1953 eruption of Crater Peak and formed dams as long as $\sim 2 \mathrm{~km}$, widths of at least $200 \mathrm{~m}$, and heights as much as 60 $\mathrm{m}$ above the modern floodplain of the Chakachatna River (Waythomas, 2001, fig. 4). A dam this size would impound up to $4.5 \times 10^{8} \mathrm{~m}^{3}$ of meltwater in the valley. According to the dam-failure model, maximum peak flood discharges produced by failure of the largest late Holocene lahar dams were between $940 \mathrm{~m}^{3} \mathrm{~s}^{-1}$ and $6.2 \times 10^{5} \mathrm{~m}^{3} \mathrm{~s}^{-1}$ (Waythomas, 2001, table 2).

Juhle and Coulter (1955) reported direct observations of the 1953 eruption of Crater Peak satellite vent and the effects of the eruption. Heavy rains and copious melting of snow and ice in the Crater Peak area incorporated volcaniclastic sediments to produce lahars that filled steep downslope 
gullies with up to $\sim 15 \mathrm{~m}$ of noncohesive, debris-laden mud and dumped bouldery gravels with sand and silt matrices and blocks of glacial ice up to $3 \mathrm{~m}$ across to build temporary dams across the Chakachatna River at the mouths of the gullies. As a result, a temporarily impounded meltwater lake filled the upper Chakachatna River valley for $\sim 8 \mathrm{~km}$ to an estimated depth of $\sim 20 \mathrm{~m}$ and had a volume of $\sim 1.2 \times 10^{8} \mathrm{~m}^{3}$ (Waythomas, 2001). Using equations for the dam-break model of Walder and O'Connor (1997), Waythomas (2001, table 2) estimated that maximum peak flood discharges resulting from failure of the 1953 lahar dams ranged from $1.8 \times 10^{3}$ $\mathrm{m}^{3} \mathrm{~s}^{-1}$ to as much as $1.2 \times 10^{6} \mathrm{~m}^{3} \mathrm{~s}^{-1}$.

During the 1992 eruptions of Crater Peak, local pyroclastic flows melted snow and ice and generated debris-rich lahars that built slightly smaller debris dams than in 1953 (Meyer and Trabant, 1995; Waitt, 1995). The Chakachatna River was temporarily blocked, and a short-lived lake that was $\sim 10 \mathrm{~m}$ deep and had an estimated volume of $3.2 \times 10^{7}$ $\mathrm{m}^{3}$ was impounded (Waythomas, 2001). Based on the damfailure model, Waythomas (2001, table 2) estimated that maximum peak flood flows due to failure of the 1992 lahar dam ranged from $\sim 997 \mathrm{~m}^{3} \mathrm{~s}^{-1}$ to as much as $6.6 \times 10^{5} \mathrm{~m}^{3} \mathrm{~s}^{-1}$.

Thus the floodplain and most of the broad alluvial fan in the Chakachatna-McArthur Embayment are expected to be inundated by significant flooding when periodic eruptions of Crater Peak produce even relatively small lahar dams that block the Chakachatna River. However, massive outburst flooding from another sector collapse of the Mount Spurr edifice and deposition of another massive debris avalanche is extremely unlikely in the near future (Waythomas and Nye, 2002).

During a period of heavy rainfall in August 1971 the discharge from Lake Chakachamna increased, widening the narrow channel between the extended terminus of Barrier Glacier and the bedrock wall to the south (Meyer and Trabant, 1995). The resulting flood attained a peak discharge of $\sim 13.3 \times 10^{3} \mathrm{~m}^{3} \mathrm{~s}^{-1}$, and $\sim 2.9 \times 10^{8} \mathrm{~m}^{3}$ of impounded waters were released as a major flood down the Chakachatna River. Theoretically a significant advance of Barrier Glacier at the eastern end of Lake Chakachamna could block the lake drainage and raise the lake level enough to destabilize the lower glacier and produce a similarly significant outburst flood. However, Barrier Glacier is not presently advancing and under modern warming climatic conditions is not likely to thicken and advance. Nonetheless, the condition of the glacier should be periodically monitored.

\section{MCARTHUR RIVER DRAINAGE}

Blockade Glacier impounds Blockade Lake, which has a surface area of $\sim 19 \mathrm{~km}^{2}$, and several smaller ice-marginal lakes (Post and Mayo, 1971, pl. 2). Those lakes drain subglacially every few years, but flood-recurrence intervals are not known. During summer 2010, fountaining in the terminal lake of Blockade Glacier indicated that considerable subglacial flow was occurring, probably through subglacial channels draining ice-impounded lakes. During high-volume flood events, the floodplain of McArthur River would be severely impacted, but the risk is low because of the low exposure.

\section{SUMMARY}

The 2,220 $\mathrm{km}^{2}$ Tyonek map area near the northwestern shore of upper Cook Inlet contains important petroleum, coal, aggregate, geothermal, and timber resources. This report provides basic surficial-geologic information useful for exploiting those resources and planning future utility corridor developments.

Glaciers invaded the map area several times during the Quaternary Period. Subdued Blueberry Hill drift (MIS 6?) is locally preserved near Lone Ridge, outside the limits of the Upper Chuitna moraine (MIS 4), which is associated with a discontinuous ring of granitic and volcanic erratics along the edge of the high-level volcaniclastic plateau between Tyonek and Mount Spurr volcano. Below the level of the penultimate (MIS 4) glaciation, high-relief moraines of the last major (MIS 2) glaciation document ice expansions from the Capps Glacier trough, the southern Susitna Lowland, and the Chakachatna-McArthur Embayment. Comparison of tillpebble compositions supports correlation of MIS 2 moraines in the Tyonek map area with moraines of the Naptowne glaciation near Nikiski on the northwestern Kenai Peninsula. Small moraines close to modern glacier margins document minor Neoglacial and Little Ice Age glacier advances during the Holocene.

Major landslides in the West Foreland (middle Eocene) and Tyonek (early Oligocene-middle Miocene) Formations are encroaching on the southwestern, northeastern, and eastern margins of the high-level volcaniclastic plateau. Physiographic relations indicate that currently active landsliding began after the last major glaciation and an older episode probably began after the penultimate glaciation. An incipient, north-striking trellis drainage system on the volcaniclastic plateau could be evidence that the plateau is spreading. A large, mid-Holocene volcanic-debris avalanche resulted from collapse of the south flank of the Mt. Spurr edifice (Waythomas, 2001, 2007; Waythomas and Nye, 2002). Reinterpretation of the Granite Point bluff section demonstrates that the Kaloa deposits there record subestuarine landslides and debris flows late in the last major glaciation, not evidence of multiple Tertiary glaciations as previously proposed.

Physiographic evidence demonstrates that the Lake Clark fault has not produced surface ruptures for at least $30 \mathrm{ka}$ and probably for at least $60 \mathrm{ka}$, and possibly for $130 \mathrm{ka}$.

Physiographic and stratigraphic evidence indicates that collossal outburst flooding periodically occurred down the Beluga River during the past $\sim 17 \mathrm{ka}$, when glacier-impounded lakes suddenly drained; massive jökulhlaups continue to episodically inundate that drainage. Temporary damming of the Chakachatna River valley by the massive mid-Holocene volcanic-debris avalanche from the southern flank of the Mt. Spurr massif ultimately produced a massive outburst flood in that drainage. In the near future, it is unlikely that another sector collapse or thickening and advance of glaciers on the southern flank of the Mt. Spurr massif will dam the eastern end of Lake Chakachamna and again produce outburst flooding down the Chakachatna River. 


\section{ACKNOWLEDGMENTS}

We worked as members of a team of geologists on the staffs of the Alaska Division of Geological \& Geophysical Surveys and Alaska Division of Oil and Gas, including, in alphabetical order: Paul Decker, Brent Elliott, Larry Freeman, Bob Gillis, Laura (Silliphant) Gregersen, Ken Helmold, Trystan Herriott, Dave LePain, Dave Mauel, and Shaun Peterson. Dave LePain and Bob Gillis both provided effective leadership. Excellent assistance in the field was provided by interns Kandace Krejci, Jake Mongrain, Keane Richards, and Garrett Speeter. Our U.S. Geological Survey colleagues Tom Ager, Andy Calvert, Michelle Coombs, and Rick Stanley kindly provided insightful information related to their investigations that was very helpful to ours. Expertise provided by our Purdue University colleagues Ken Ridgway and Emily Finzel was essential to our understanding of the geologic framework and tectonics of the study area. Support by the Cottonwood Camp staff ensured that we were well fed, showered frequently, slept dry, and were therefore willing and able to venture into the field when the weather allowed. When we could fly, helicopter pilots Ray Hodges, Tom Ratledge, Chuck Redd, and Joe Trudo safely landed us where we needed to go and brought us intact back to base camp at the end of the day. We greatly appreciated permission to work in lands owned by Cook Inlet Region Incorporated (CIRI), Tyonek Native Corporation, and Tyonek Village Corporation. We particularly appreciate constructive technical reviews provided by Chris Waythomas (USGS) and Trent Hubbard (DGGS), which helped clarify this report. This publication was funded by the State of Alaska and the National Cooperative Geologic Mapping Program's STATEMAP program (awards G09AC00177 and G10AC00321), administered by the U.S. Geological Survey.

\section{REFERENCES}

Barnes, F.F., 1966, Geology and coal resources of the Beluga-Yentna region, Alaska: U.S. Geological Survey Bulletin 1202-C, 54 p., 3 map sheets, scales 1:63,360 and $1: 250,000$.

Boss, R.F., Lennon, R.B., and Wilson, B.W., 1976, Middle Ground Shoal oil field, Alaska, in Braunstein, J., ed., North American oil and gas fields: American Association of Petroleum Geologists Memoir, v. 24, p. 1-22.

Briner, J.P., and Kaufman, D.S., 2008, Late Pleistocene mountain glaciation in Alaska-Key chronologies: Journal of Quaternary Science, v. 23, no. 6-7, p. 659-670.

Briner, J.P., Kaufman, D.S., Manley, W.E., Finkel, R.C., and Caffee, M.W., 2005, Cosmogenic exposure dating of late Pleistocene moraine stabilization in Alaska: Geological Society of America Bulletin, v. 117, no. 7-8, p. $1,108-1,120$.

Combellick, R.A. and Pinney, D.S., 1995, Radiocarbon age of probable Hayes tephra, Kenai Peninsula, Alaska, in Combellick, R.A., and Tannian, Fran, eds., Short Notes on Alaska Geology 1995: Alaska Division of Geological \& Geophysical Surveys Professional Report 117A, p. 1-9. doi: $\underline{10.14509 / 2317}$
Cossart, E., Braucher, R., Fort, M., Bourlès, D.L., and Carcaillet, J., 2008, Slope instability in relation to glacial debuttressing in alpine areas (Upper Durance catchment, southeastern France) - Evidence from field data and ${ }^{10} \mathrm{Be}$ cosmic ray exposure ages: Geomorphology, v. 95 , no. 1-2, p. 3-26. doi:10.1016/i.geomorph.2006.12.022

Cowan, E.A., and Powell, R.D., 1991, Ice-proximal sediment accumulation rates in a temperate glacial fjord, southeast Alaska, in Anderson, J.B. and Ashley, G.M., eds., Glacial marine sedimentation-Paleoclimatic significance: Geological Society of America Special Paper 261, p. 75-93.

Crandell, D.W., 1989, Gigantic debris avalanche of Pleistocene age from ancestral Mount Shasta volcano, California, and debris-avalanche hazard zonation: U.S. Geological Survey Bulletin 1861, 32 p.

Csejtey, Béla, Jr., Mullen, M.W., Cox, D.P., and Stricker, G.D., 1992, Geology and geochronology of the Healy Quadrangle, south-central Alaska: U.S. Geological Survey Miscellaneous Investigations Map I-1961, 63 p., 1 sheet, scale 1:250,000.

Decker, John, Bergman, S.C., Blodgett, R.B., Box, S.E., Bundtzen, T.K., Clough, J.G., Coonrad, W.L., Gilbert, W.G., Miller, M.L., Murphy, J.M., Robinson, M.S., and Wallace, W.K., 1994, Geology of southwestern Alaska, in Plafker, George, and Berg, H.C., eds., The geology of Alaska: Boulder, Geological Society of America, The geology of North America, v. G-1, p. 285-310.

Dettermann, R.L., Hudson, Travis, Plafker, George, Tysdal, R.G., and Hoare, J.M., 1976, Reconnaissance geologic map along Bruin Bay and Lake Clark faults in Kenai and Tyonek quadrangles, Alaska: U.S. Geological Survey Open-File Map 76-477, 4 p., 1 sheet, scale 1:250,000.

Eyles, Nicholas, and McCabe, A.M., 1989, The late Devensian $(<22,000$ B.P.) Irish Sea basin-The sedimentary record of a collapsed ice sheet margin: Quaternary Science Reviews, v. 8, no. 4, p. 307-351.

Garchar, Laura, and Wendlandt, R., 2012, Geochemistry of a volcanic hydrothermal system at Mount Spurr, Alaska: Geothermal Resources Council Transactions, v. 36, p. 655-661.

Gillis, R.J., LePain, D.L., Ridgway, K.D., and Finzel, E.S., 2009, A reconnaissance view of an unnamed fault near Capps Glacier, northwestern Cook Inlet basin, and its potential as a regional-scale, basin-controlling structure: Alaska Division of Geological \& Geophysical Surveys Preliminary Interpretive Report 2009-3, 9 p. doi:10.14509/19503

Haeussler, P.J., and Saltus, R.W., 2011, Location and extent of Tertiary structures in Cook Inlet basin, Alaska, and mantle dynamics that focus deformation and subsidence, in Dumoulin, J.A., and Galloway, J.P., eds., Studies by the U.S. Geological Survey in Alaska 2008-2009: U.S. Geological Survey Professional Paper 1776-D, 26 p.

Haeussler, P.J., Bruhn, R.L., and Pratt, T.L., 2000, Potential seismic hazards and tectonics of the upper Cook Inlet basin, Alaska, based on analyses of Pliocene and younger deformation: Geological Society of America Bulletin, v. 1122 , no. 9 , p. $1,414-1,429$. 
Hansen, W.R., 1965, Effects of the earthquake of March 27, 1964, at Anchorage, Alaska: U.S. Geological Survey Professional Paper 542-A, 68 p., 2 sheets, scales 1:480 and 1:2,400. http://pubs.usgs.gov/pp/0542a/

Harp, E.L., Jibson, R.W., Kayen, R.E., Keefer, D.K., Sherrod, B.L., Carver, G.A., Collins, B.D., Moss, R.E.S., and Sitar, N., 2003, Landslides and liquefaction triggered by the M 7.9 Denali Fault earthquake of 3 November 2002: GSA Today, v. 13, no. 8, p. 4-10.

Herriott, T.M., Nye, C.J., Reger, R.D., Wartes, M.A., LePain, D.L., and Gillis, R.J., 2011, Sedimentology, age, and geologic context of a Pleistocene volcaniclastic succession near Spurr volcano, Alaska [abs.]: Anchorage, American Association of Petroleum Geologists Pacific Section Meeting Program with Abstracts, p. 62-63.

Herriott, T.M., Nye, C.J., Reger, R.D., Wartes, M.A., LePain, D.L., and Gillis, R.J., 2014, Geologic context, age constraints, and sedimentology of a Pleistocene volcaniclastic succession near Mount Spurr volcano, south-central Alaska: Alaska Division of Geological \& Geophysical Surveys Report of Investigation 2014-2, 35 p. doi:10.14509/27261

Juhle, Werner, and Coulter, Henry, 1955, The Mt. Spurr eruption, July 9, 1953: EOS, Transactions of the American Geophysical Union, v. 36, no. 2, p. 199-202.

Karlstrom, T.N.V., 1964, Quaternary geology of the Kenai Lowland and glacial history of the Cook Inlet region, Alaska: U.S. Geological Survey Professional Paper 443, 69 p., 6 sheets, various scales.

Keith, T.E.C., 1995, The 1992 eruption of Crater Peak vent, Mount Spurr volcano, Alaska: U.S. Geological Survey Bulletin 2139, 220 p.

Koehler, R.D., and Reger, R.D., 2009, Lake Clark fault, assessment of tectonic activity based on reconnaissance mapping of glacial deposits, northwestern Cook Inlet, Alaska [poster]: EOS Transactions, American Geophysical Union, Fall Meeting Supplement, Abstract G33B0658, San Francisco, CA, December 16, 2009: Alaska Division of Geological \& Geophysical Surveys, 1 sheet. doi:10.14509/21845

Koehler, R.D., and Reger, R.D., 2011, Reconnaissance evaluation of the Lake Clark fault, Tyonek area, Alaska: Alaska Division of Geological \& Geophysical Surveys Preliminary Interpretive Report 2011-1, 8 p. doi:10.14509/22221

Magoon, L.B., Adkison, W.L., and Egbert, R.M., 1976, Map showing geology, wildcat wells, Tertiary plant fossil localities, K-Ar age dates, and petroleum operations, Cook Inlet area, Alaska: U.S. Geological Survey Miscellaneous Investigations Map I-1019, 3 sheets, scale 1:250,000.

Mann, D.H., and Peteet, D.M., 1994, Extent and timing of the last glacial maximum in southwestern Alaska: Quaternary Research, v. 42, no. 2, p. 136-148.

Matmon, A., Briner, J.P., Carver, G.A., Bierman, P., and Finkel, R.C., 2010, Moraine chronosequence of the Donnelly Dome region, Alaska: Quaternary Research, v. 74, no. 1, p. 63-72.

Meyer, D.F., and Trabant, D.C., 1995, Lahars from the 1992 eruptions of Crater Peak, Mount Spurr Volcano, Alaska, in Keith, T.E.C., ed., The 1992 eruptions of Crater Peak vent, Mount Spurr Volcano, Alaska: U.S. Geological Survey Bulletin 2139, p. 183-198.

Nye, C.J., and Turner, D.L., 1990, Petrology, geochemistry, and age of the Spurr volcanic complex, eastern Aleutian arc: Bulletin of Volcanology, v. 52, no. 3, p. 205-226.

Odum, J.K., 1986, Compilation of field and laboratory geotechnical test data for U.S. Geological Survey drill holes 1C-79, 2C-80, CW 81-2, and CE 82-1, Beluga resource area, upper Cook Inlet region, Alaska: U.S. Geological Survey Open-File Report 86-382, 8 p., 4 sheets.

Odum, J.K., Yehle, L.A., Schmoll, H.R., Gardner, C.A., and Dearborn, L.L., 1986, Lithological, geotechnical properties analysis, and geophysical log interpretation of U.S. Geological Survey drill holes 1C-79, 2C-80, CW 81-2, and CE 82-1, Tyonek Formation, upper Cook Inlet region, Alaska: U.S. Geological Survey Bulletin 1835, 27 p.

Post, Austin, and Mayo, L.R., 1971, Glacier dammed lakes and outburst floods in Alaska: U.S. Geological Survey Hydrologic Investigations Atlas HA-455, 10 p., 3 sheets, scale 1:1,000,000.

Reed, B.L., Miesch, A.T., and Lanphere, M.A., 1983, Plutonic rocks of Jurassic age in the Alaska-Aleutian Range batholith - Chemical variation and polarity: Geological Society of America Bulletin, v. 94, no. 10, p. 1,232-1,240.

Reed, J.C., Jr., 1961, Geology of the Mount McKinley Quadrangle, Alaska: U.S. Geological Survey Bulletin 1108-A, 36 p., 1 sheet, scale 1:250,000.

Reger, R.D., 2009, Reinterpretation of the Kaloa deposits near Granite Point, northwestern Cook Inlet, Alaska: Alaska Division of Geological \& Geophysical Surveys Preliminary Interpretive Report 2009-2, 8 p. doi:10.14509/18241

Reger, R.D., and Pinney, D.S., 1996, Late Wisconsin glaciation of the Cook Inlet region with emphasis on Kenai Lowland and implications for early peopling, in Davis, N.Y., and Davis, W.E., eds., Adventures through timeReadings in the anthropology of Cook Inlet, Alaska: Anchorage, Cook Inlet Historical Society, p. 15-35.

1997, Last major glaciation of Kenai Lowland, in Karl, S.M., Vaughn, N.R., and Ryherd, T.J., eds., 1997 guide to the geology of the Kenai Peninsula, Alaska: Anchorage, Alaska Geological Society, p. 54-67.

Reger, R.D., and Updike, R.G., 1983, Upper Cook Inlet and the Matanuska Valley, in Péwé, T.L., and Reger, R.D., eds., Guidebook to permafrost and Quaternary geology along the Richardson and Glenn highways between Fairbanks and Anchorage, Alaska: Alaska Division of Geological \& Geophysical Surveys Guidebook 1, p. 185-263, 1 sheet, scale 1:250,000. doi:10.14509/263

Reger, R.D., Combellick, R.A., and Brigham-Grette, Julie, 1995, Late-Wisconsin events in the Upper Cook Inlet region, southcentral Alaska, in Combellick, R.A., and Tannian, Fran, eds., Short notes on Alaska Geology 1995: Alaska Division of Geological \& Geophysical Surveys Professional Report 117D, p. 33-45. doi: 10.14509/2320 Reger, R.D., Pinney, D.S., Burke, R.M., and Wiltse, M.A., 1996, Catalog and preliminary analyses of geologic data related to middle to late Quaternary deposits, eastern 
and northern Cook Inlet region, Alaska: Alaska Division of Geological \& Geophysical Surveys Report of Investigations $95-6,188$ p., 5 sheets, scale 1:250,000, 1 sheet 1 inch $=3 \mathrm{ft}$. doi: $10.14509 / 2520$

Reger, R.D., Sturmann, A.G., Berg, E.E., and Burns, P.A.C., 2007, A guide to the late Quaternary history of northern and western Kenai Peninsula, Alaska: Alaska Division of Geological \& Geophysical Surveys Guidebook 8, 112 p., 6 sheets, scale 1:63,360. doi:10.14509/15941

Riehle, J.R., 1985, A reconnaissance of the major Holocene tephra deposits in the upper Cook Inlet region, Alaska: Journal of Volcanology and Geothermal Research, v. 26, no. 1-2, p. 37-74.

1994, Heterogeneity, correlatives, and proposed stratigraphic nomenclature of Hayes tephra set H, Alaska: Quaternary Research, v. 41, no. 3, p. 285-288.

Riehle, J.R., and Emmel, K.S., 1980, Photointerpretation map of the surficial geology, Polly Creek to McArthur River, Cook Inlet, Alaska: Alaska Division of Geological \& Geophysical Surveys Geologic Report 64, 2 sheets, scale 1:63,360.

Riehle, J.R., Ager, T.A., Reger, R.D., Pinney, D.S., and Kaufman, D.S., 2008, Stratigraphic and compositional complexities of the late Quaternary Lethe tephra in south-central Alaska: Quaternary International, v. 178, p. 210-228.

Riehle, J.R., Bowers, P.M., and Ager, T.A., 1990, The Hayes tephra deposits, an upper Holocene marker horizon in south-central Alaska: Quaternary Research, v. 33, no. 3, p. 276-290.

Schmoll, H.R., and Yehle, L.A., 1978, Generalized physiography and geology of the Beluga coal field and vicinity, south-central Alaska, in Johnson, K.M., ed., The United States Geological Survey in Alaska-Accomplishments during 1977: U.S. Geological Survey Circular 772-B, p. B73-B76.

1983, Glaciation in the upper Cook Inlet basin-A preliminary re-examination based on geologic mapping in progress [abs.], in Thorson, R.M., and Hamilton, T.D., eds., Glaciation in Alaska-Extended abstracts from a workshop: University of Alaska Museum Occasional Paper 2, p. 75-81.

1986, Pleistocene glaciation of the upper Cook Inlet basin, in Hamilton, T.D., Reed, K.M., and Thorson, R.M., eds., Glaciation in Alaska-The geologic record: Anchorage, Alaska Geological Society, p. 193-218.

1987, Surficial geologic map of the northwestern quarter of the Tyonek A-4 Quadrangle, south-central Alaska: U.S. Geological Survey Miscellaneous Field Studies Map MF-1934, 1 sheet, scale 1:31,680.

Schmoll, H.R., Chleborad, A.F., Yehle, L.A., Gardner, C.A., and Pasch, A.D., 1981, Reconnaissance engineering geology of the Beluga coal resource area, south-central Alaska, in Rao, P.D., and Wolff, E.N., eds., Focus on Alaska's coal '80: Fairbanks, University of Alaska Mineral Industries Research Laboratory Report 50, p. 92-110.

Schmoll, H.R., Szabo, B.J., Rubin, Meger, and Dobrovolny, Ernest, 1972, Radiometric dating of marine shells from the Bootlegger Cove clay, Anchorage area, Alaska: Geological Society of America Bulletin, v. 83, p. 1,107-1,113.

Schmoll, H.R., Yehle, L.A., and Gardner, C.A., 1981, Preliminary geologic map of the Congahbuna area, Cook Inlet region, Alaska: U.S. Geological Survey Open-File Report 81429, 8 p., 1 sheet, scale 1:63,360.

Schmoll, H.R., Yehle, L.A., Gardner, C.A., and Odum, J.K., 1984, Guide to surficial geology and glacial stratigraphy in the upper Cook Inlet basin: Anchorage, Alaska Geological Society guidebook, $89 \mathrm{p}$.

Schmoll, H.R., Yehle, L.A., and Updike, R.G., 1999, Summary of Quaternary geology of the Municipality of Anchorage, Alaska: Quaternary International, v. 60, p. 3-36.

Shirzaei, M., Walter, T.R., Nankali, H.R., and Holohan, E.P., 2011, Gravity-driven deformation of Damavand Volcano, Iran, detected through InSAR time series: Geology, v. 39, no. 3, p. 251-254. doi:10.1130/G31779.1

Siebert, Lee, 1984, Large volcanic debris avalanches - Characteristics of source areas, deposits, and associated eruptions: Journal of Volcanology and Geothermal Research, v. 22, no. 3-4, p. 163-197.

Sturm, Matthew, 1986, Formation of a strandline during the 1984 jökulhlaup of Strandline Lake: Arctic, v. 39, no. 3, p. 267-269.

Sturm, Matthew, and Benson, C.S., 1989, Jökulhlaups from Strandline Lake, Alaska, with special attention to the 1982 event: Alaska Division of Geological \& Geophysical Surveys Report of Investigation 88-10, 19 p. doi:10.14509/2458

Sturm, Matthew, Begét, James, and Benson, Carl, 1987, Observations of jökulhlaups from ice-dammed Strandline Lake, Alaska-Implications for paleohydrology, in Mayer, L., and Nash, D., eds., Catastrophic flooding: Boston, Allen and Unwin, p. 79-94.

Wahrhaftig, Clyde, 1965, Physiographic divisions of Alaska: U.S. Geological Survey Professional Paper 482, 52 p., 6 sheets, various scales.

Waitt, R.B., 1995, Hybrid wet flows formed by hot pyroclasts interacting with snow during the 1992 eruptions of Crater Peak, Mount Spurr volcano, Alaska, in Keith, T.E.C., ed., The 1992 eruptions of Crater Peak vent, Mount Spurr volcano, Alaska: U.S. Geological Survey Bulletin 2139, p. 107-118.

Walder, J.S., and O'Connor, J.E., 1997, Methods for predicting peak discharge of floods caused by failure of natural and constructed earthen dams: Water Resources Research, v. 33 , no. 10 , p. $2,337-2,348$.

Waythomas, C.F., 2001, Formation and failure of volcanic debris dams in the Chakachatna River valley associated with eruptions of the Spurr volcanic complex, Alaska: Geomorphology, v. 39, p. 111-129.

2007, Mid-Holocene sector collapse at Mount Spurr volcano, south-central Alaska, in Studies by the U.S. Geological Survey in Alaska, 2006: U.S. Geological Survey Professional Paper 1739-C, version 1.0, 15 p.

Waythomas, C.F., and Miller, T.P., 2002, Preliminary volcano-hazard assessment for Hayes volcano, Alaska: 
U.S. Geological Survey Open-File Report 02-072, 27 p., 1 sheet, scale 1:250,000.

Waythomas, C.F., and Nye, C.J., 2002, Preliminary volcanohazard assessment for Mount Spurr volcano, Alaska: U. S. Geological Survey Open-File Report 01-482, 39 p.

Waythomas, C.F., and Wallace, K.L., 2002, Flank collapse of Mount Wrangell, Alaska, recorded by volcanic mass-flow deposits in the Copper River lowland: Canadian Journal of Earth Sciences, v. 39, no. 8, p. 1,257-1,279.

Wolfe, J.A., Hopkins, D.M., and Leopold, E.B., 1966, Tertiary stratigraphy and paleobotany of the Cook Inlet region, Alaska: U.S. Geological Survey Professional Paper 398-A, p. A1-A29.
Yehle, L.A., Schmoll, H.R., and Chleborad, A.F., 1983a, Preliminary surficial geologic map of the southwestern part of the Tyonek B-5 Quadrangle, south-central Alaska: U.S. Geological Survey Miscellaneous Field Studies Map MF-1661-B, 1 sheet, scale 1:31,680.

1983b, Preliminary surficial geologic map of the southeastern part of the Tyonek B5 Quadrangle, south-central Alaska: U.S. Geological Survey Miscellaneous Field Studies Map MF-1661-C, 1 sheet, scale 1:31,680. 